ORNL/TM-2015/22

National Weatherization Assistance Program Impact Evaluation Baseline Occupant Survey: Assessment of Client Status and Needs

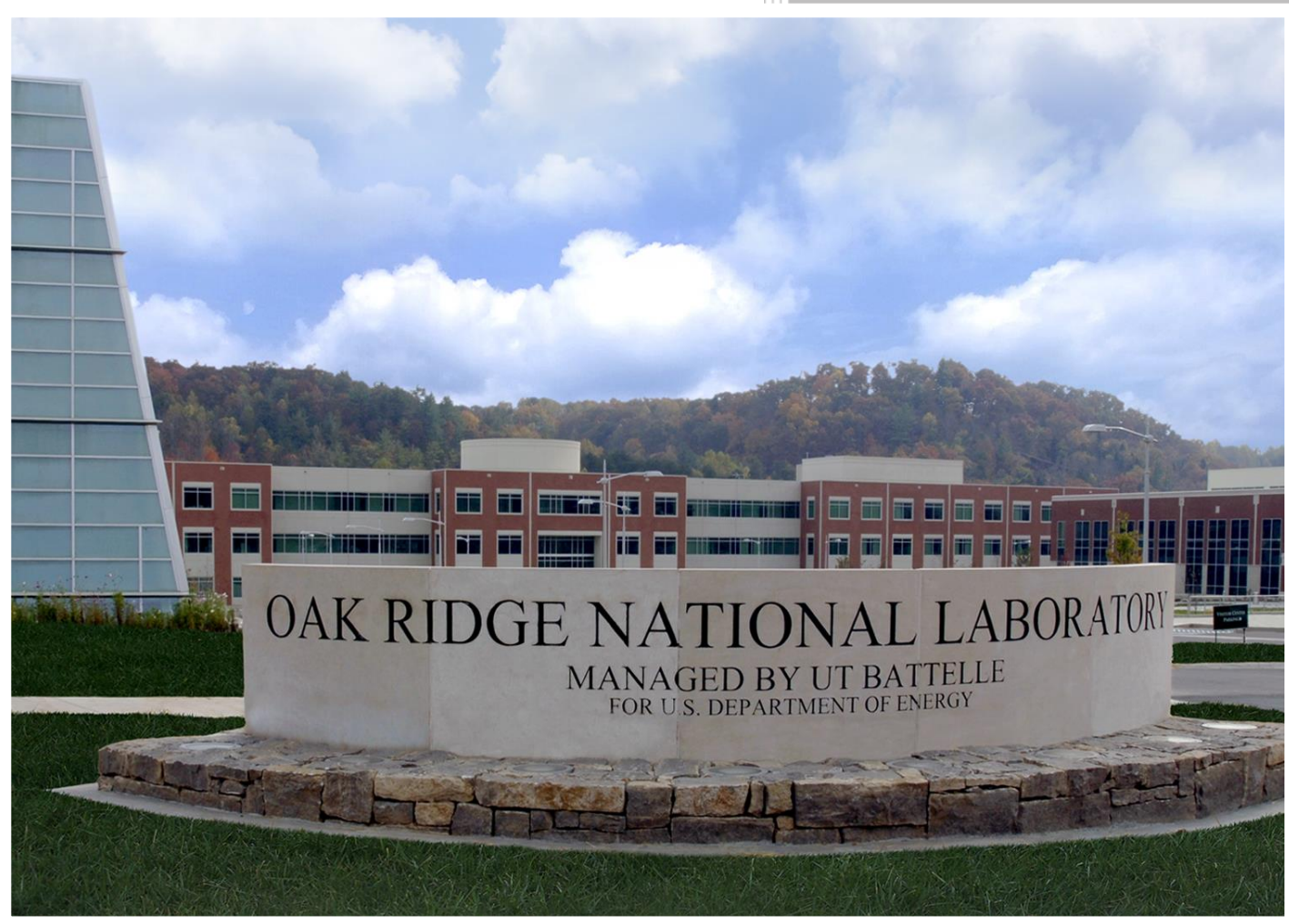

David Carroll Jacqueline Berger, Ph.D. Carolyn Miller Colleen Driscoll

September 2014 


\section{DOCUMENT AVAILABILITY}

Reports produced after January 1, 1996, are generally available free via US Department of Energy (DOE) SciTech Connect.

Website http://www.osti.gov/scitech/

Reports produced before January 1, 1996, may be purchased by members of the public from the following source:

National Technical Information Service

5285 Port Royal Road

Springfield, VA 22161

Telephone 703-605-6000 (1-800-553-6847)

TDD 703-487-4639

Fax 703-605-6900

E-mail info@ntis.gov

Website http://www.ntis.gov/help/ordermethods.aspx

Reports are available to DOE employees, DOE contractors, Energy Technology Data Exchange representatives, and International Nuclear Information System representatives from the following source:

Office of Scientific and Technical Information

PO Box 62

Oak Ridge, TN 37831

Telephone 865-576-8401

Fax 865-576-5728

E-mail reports@osti.gov

Website http://www.osti.gov/contact.html

This report was prepared as an account of work sponsored by an agency of the United States Government. Neither the United States Government nor any agency thereof, nor any of their employees, makes any warranty, express or implied, or assumes any legal liability or responsibility for the accuracy, completeness, or usefulness of any information, apparatus, product, or process disclosed, or represents that its use would not infringe privately owned rights. Reference herein to any specific commercial product, process, or service by trade name, trademark, manufacturer, or otherwise, does not necessarily constitute or imply its endorsement, recommendation, or favoring by the United States Government or any agency thereof. The views and opinions of authors expressed herein do not necessarily state or reflect those of the United States Government or any agency thereof.

ORNL Principal Investigator Dr. Bruce Tonn

\section{Evaluation Team Task Manager Jacqueline Berger, Ph.D.}


Environmental Sciences Division

\title{
NATIONAL WEATHERIZATION ASSISTANCE PROGRAM IMPACT EVALUATION - BASELINE OCCUPANT SURVEY: ASSESSMENT OF CLIENT STATUS AND NEEDS
}

\author{
David Carroll, APPRISE \\ Jacqueline Berger, Ph.D., APPRISE \\ Carolyn Miller, Carolyn Miller Consulting \\ Colleen Driscoll, APPRISE
}

Date Published: September 2014

\author{
Prepared by \\ OAK RIDGE NATIONAL LABORATORY \\ Oak Ridge, Tennessee 37831-6283 \\ managed by \\ UT-BATTELLE, LLC \\ for the \\ US DEPARTMENT OF ENERGY \\ under contract DE-AC05-00OR22725
}





\section{CONTENTS}

Page

LIST OF TABLES $\mathrm{V}$

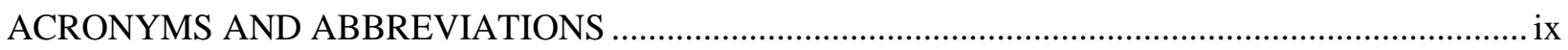

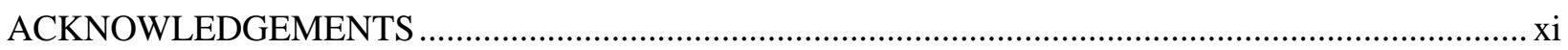

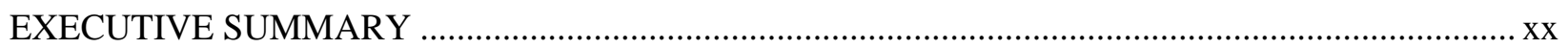

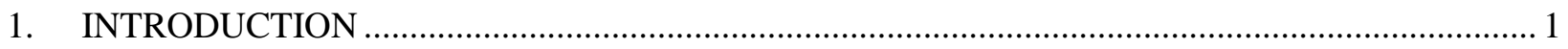

1.1 NATIONAL WEATHERIZATION ASSISTANCE PROGRAM EVALUATION

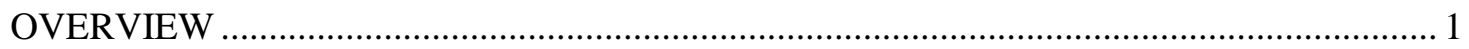

1.2 OCCUPANT SURVEY STUDY OVERVIEW ......................................................... 2

1.3 ORGANIZATION OF THE BASELINE OCCUPANT SURVEY REPORT ….................... 3

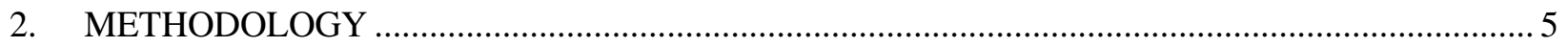

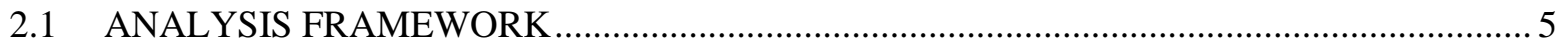

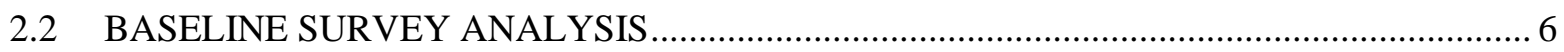

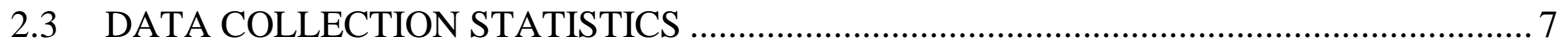

3. HOUSEHOLD AND HOUSING UNIT CHARACTERISTICS ................................................. 9

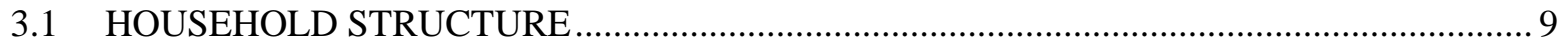

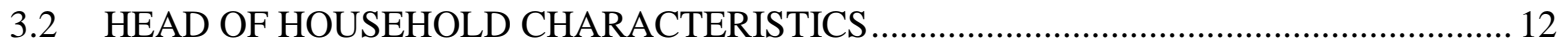

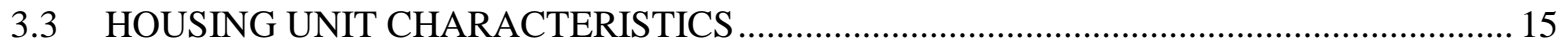

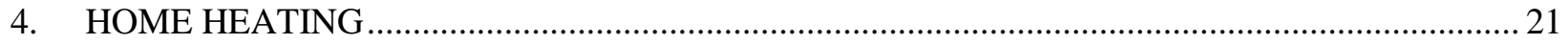

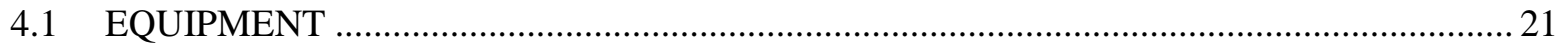

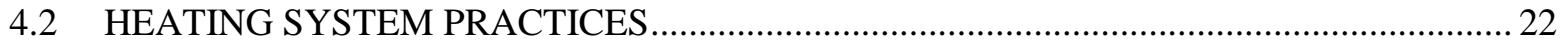

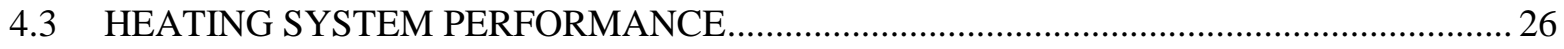

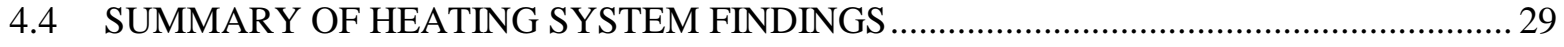

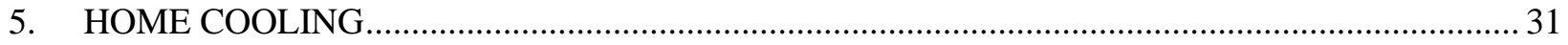

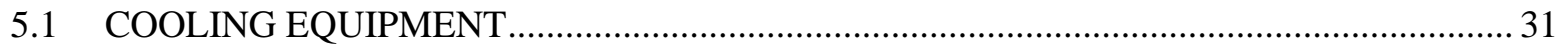

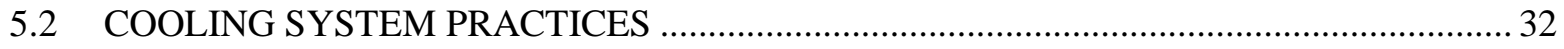

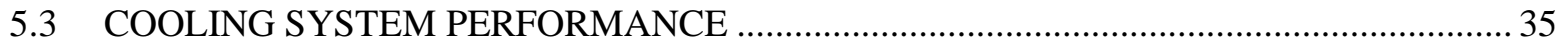

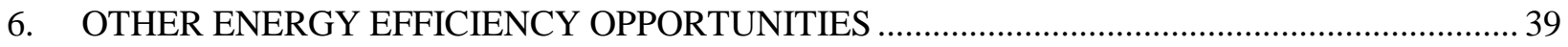

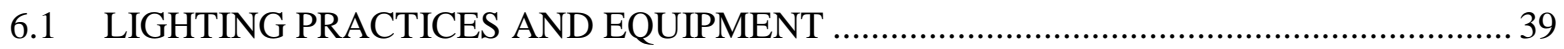

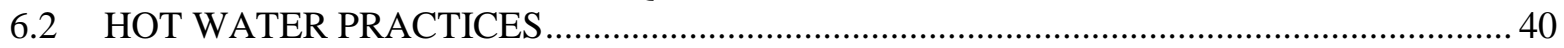

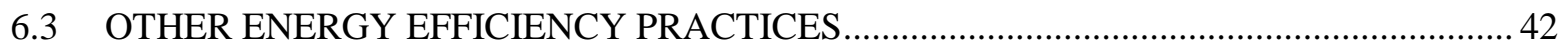

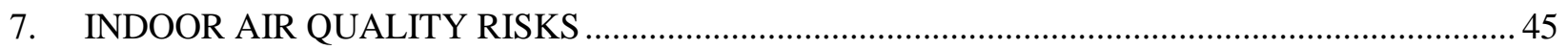

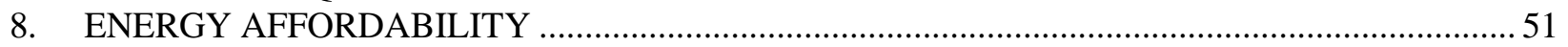

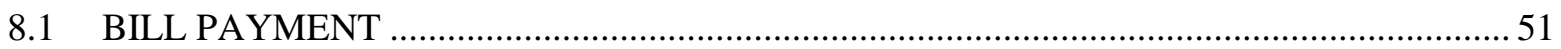

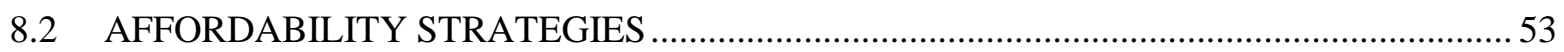

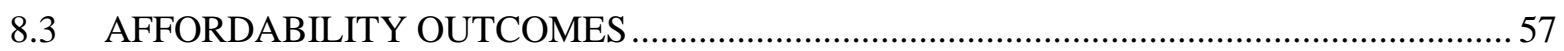

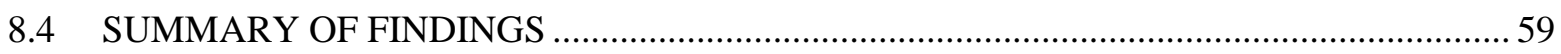

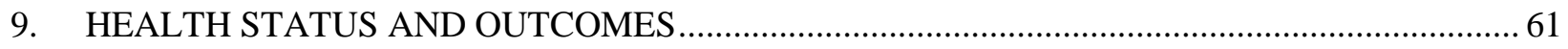

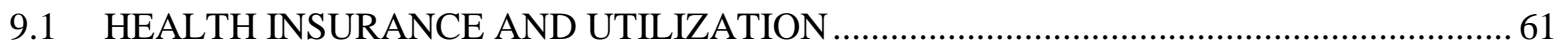

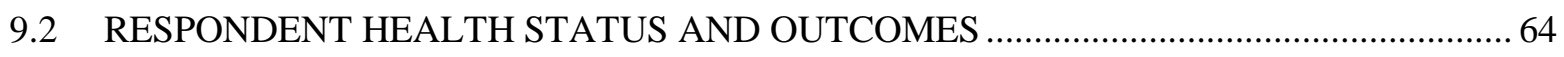

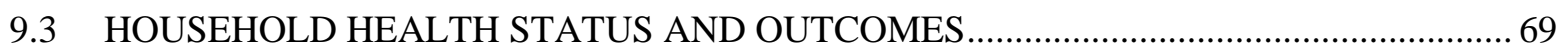

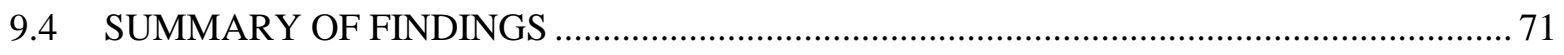

APPENDIX A. BASELINE OCCUPANT SURVEY INSTRUMENT ................................................... 1 



\section{LIST OF TABLES}

\section{Tables}

Table 1. Summary of WAP Household Heating System Findings ......................................................xxiii

Table 2. Summary of WAP Household Cooling System Findings ...................................................... xxiv

Table 3. Summary of Findings for Indoor Air Quality Risks of WAP Households .................................xxv

Table 4. Summary of Findings on WAP Household Bill Payment Problems..........................................xxv

Table 5. Summary of Findings on WAP Household Bill Payment Strategies ......................................... xxvi

Table 6. Summary of Findings on WAP Household Energy Affordability Outcomes ............................xxvi

Table 7. Summary of Select Findings on Health Insurance Coverage and Difficulty Paying Medical Costs

Table 8. Summary of Select Findings on Health Status and Outcomes ................................................. xxi

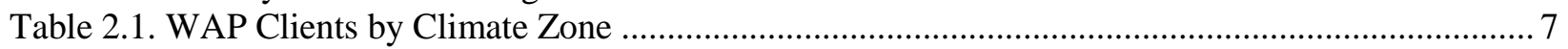

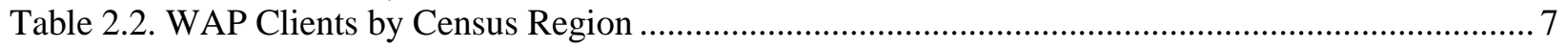

Table 2.3. WAP Clients by Demographics and Housing Unit Characteristics .......................................... 7

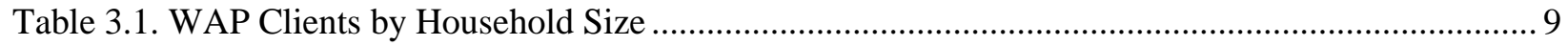

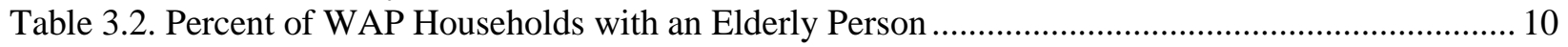

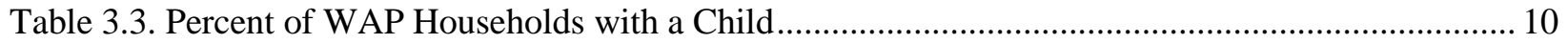

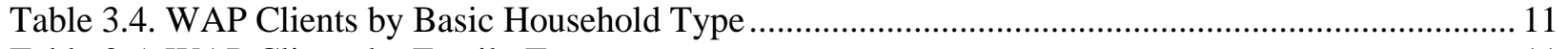

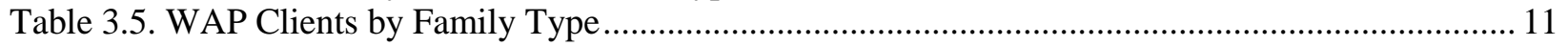

Table 3.6. WAP Clients by Elderly Household Composition ................................................................ 12

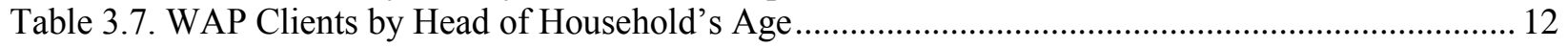

Table 3.8. WAP Clients by Head of Household's Education Level ......................................................... 13

Table 3.9. WAP Clients by Head of Household's Marital Status ............................................................... 13

Table 3.10. WAP Clients by Head of Household's Race/Ethnicity ......................................................... 13

Table 3.11. WAP Clients by Head of Household's Citizenship Status...................................................... 14

Table 3.12. WAP Clients by Primary Wage Earner's Employment Status ............................................. 14

Table 3.13. WAP Clients by Whether Primary Wage Earner Is Employed Seasonally ............................ 15

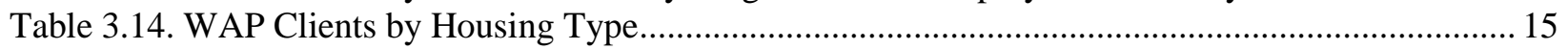

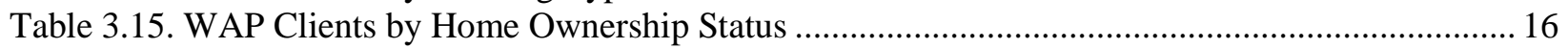

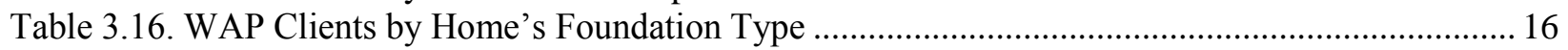

Table 3.17. WAP Clients by Whether House Has an Attached Garage..................................................... 17

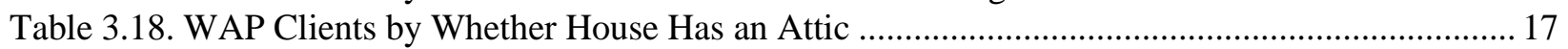

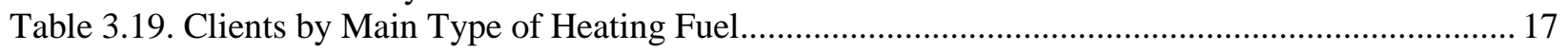

Table 3.20. WAP Clients by Whether Household Uses Secondary Source of Heat .................................. 18

Table 3.21. WAP Clients by Type of Air Conditioning Equipment ..................................................... 18

Table 3.22. Percent of WAP Clients with Other Appliances in the Household ....................................... 18

Table 4.1. WAP Clients by Type of Main Heating Equipment .......................................................... 22

Table 4.2. WAP Clients by Type of Supplemental Heating Equipment ............................................... 22

Table 4.3. WAP Clients by Median Household Temperature $\left({ }^{\circ} \mathrm{F}\right)$ at Different Times of Day During

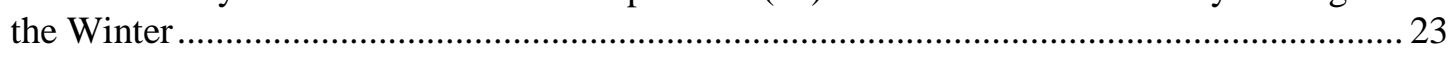

Table 4.4. WAP Clients by How Household Practices Setback in the Winter ........................................ 23

Table 4.5. WAP Clients by Whether Household Programs Setback in the Winter ................................. 23

Table 4.6. WAP Clients by Whether Someone Is Home Most or All Day During the Week .................... 24

Table 4.7. WAP Clients by When Household Last Received Furnace Maintenance ................................. 24

Table 4.8. WAP Clients by How Often Household Changes the Air Filter............................................. 25

Table 4.9. WAP Clients by Whether Household Uses a Heating Stove or Fireplace for Heat and

What Type of Wood the Household Uses ................................................................................. 25

Table 4.10. WAP Clients by Whether Household Uses a Cooking Stove for Heat.................................. 26 
Table 4.11. WAP Clients by Whether Household Uses a Portable Heater ............................................. 26

Table 4.12. WAP Clients by Whether Main Heating Equipment Broken in the Past 12 Months

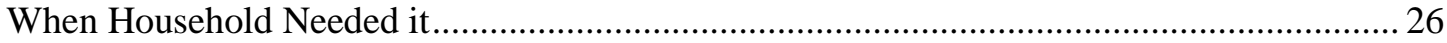

Table 4.13. WAP Clients by How Often Home Is Too Drafty ............................................................ 27

Table 4.14. WAP Clients by Comfort of Home and Temperature of Home in Winter ............................. 27

Table 4.15. WAP Clients by Household Comfort of Home and Home Draftiness in the Winter............. 28

Table 4.16. WAP Clients by How Often the Household Kept the Home at an Unsafe or Unhealthy

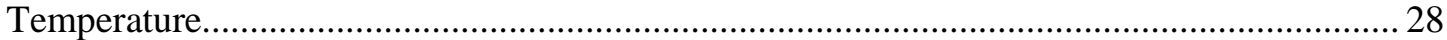

Table 4.17. WAP Clients by Whether Household Member Received Medical Attention Because the

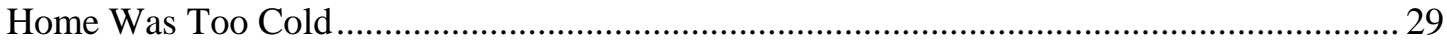

Table 4.18. WAP Clients by Difficulty Faced by Child Studying Because of Excessive Heat/Cold ........ 29

Table 4.19. Summary of WAP Household Heating System Findings .................................................... 30

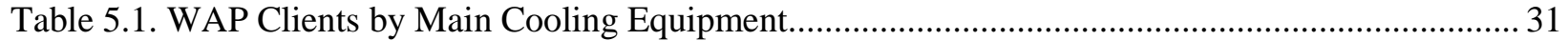

Table 5.2. WAP Clients by How Household Used AC Last Summer .................................................... 32

Table 5.3. WAP Clients by Median Household Temperature $\left({ }^{\circ} \mathrm{F}\right)$ at Different Times of Day in the

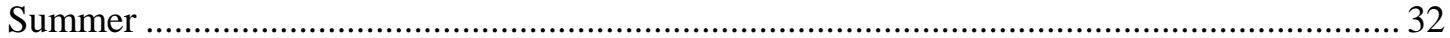

Table 5.4. WAP Clients by Whether Household Practices Setback in the Summer ................................. 33

Table 5.5. WAP Clients by Presence of Thermostat for Cooling .......................................................... 33

Table 5.6. WAP Clients by Household Programs Setback on Cooling Thermostat .................................. 33

Table 5.7. WAP Clients by Whether Household Uses Ceiling Fans in Summer...................................... 34

Table 5.8. WAP Clients by Whether Household Uses Cross Ventilation................................................. 34

Table 5.9. WAP Clients by Whether Household Closes Drapes, Curtains, Shades, Blinds ...................... 34

Table 5.10. WAP Clients by Whether Household Has Large Trees That Shade Home from the

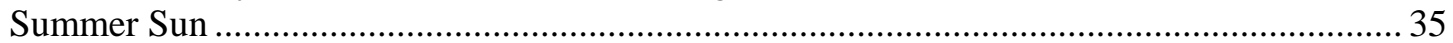

Table 5.11. WAP Clients by How Often Household Opens Windows in Summer .................................. 35

Table 5.12. WAP Clients by Whether Main Cooling Equipment Broke in Past 12 Months When

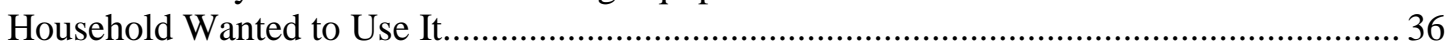

Table 5.13. WAP Clients by Comfort of Home and Temperature of Home in the Summer ....................... 36

Table 5.14. WAP Clients by Comfort of Home and Draftiness of Home in the Summer .......................... 37

Table 5.15. WAP Clients by How Often Household Keeps Home at Unsafe or Unhealthy

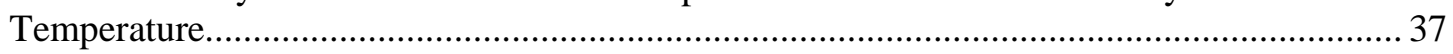

Table 5.16. WAP Clients by Whether Household Member Received Medical Attention Because Home Was Too Hot................................................................................................................ 38

Table 5.17. Summary of WAP Household Cooling System Findings ................................................... 38

Table 6.1. WAP Clients by How Often Household Leaves Lights On in Unoccupied Rooms .................. 39

Table 6.2. WAP Clients by Whether Household Purchases CFLs .................................................... 40

Table 6.3. WAP Clients by How Household Disposes of CFLs............................................................ 40

Table 6.4. WAP Clients by How Household Adjusted Water Heater Temperature in Past 12 Months ..... 41

Table 6.5. WAP Clients by Temperature of Wash Cycle for Home Washing Machine............................ 41

Table 6.6. WAP Clients by Temperature of Rinse Cycle for Home Washing Machine ............................. 41

Table 6.7. WAP Clients by Change in Household Shower Length ........................................................ 42

Table 6.8. WAP Clients by Whether Household Purchased Items with an Energy Star Label ................. 42

Table 6.9. WAP Clients by How Often Household Hangs Clothes to Dry .............................................. 43

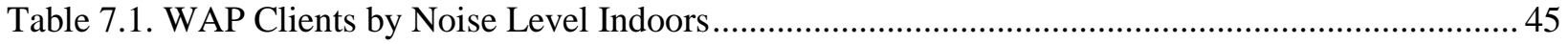

Table 7.2. WAP Clients by Level of Home Insect Infestation................................................................... 46

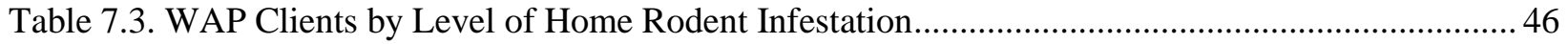

Table 7.4. WAP Clients by How Often Standing Water Observed in the Home...................................... 47

Table 7.5. WAP Clients by Presence of Frequent Mildew Odor in the Home ......................................... 47

Table 7.6. WAP Clients by Presence of Mold in the Home in the Past 12 Months.................................... 47

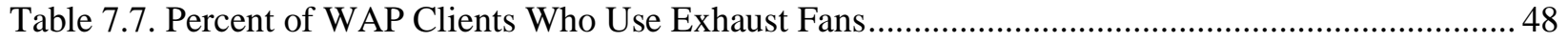

Table 7.8. WAP Clients by Heating Thermostat Type ........................................................................... 48 
Table 7.9. WAP Clients by Presence of Carbon Monoxide Monitors ................................................... 48

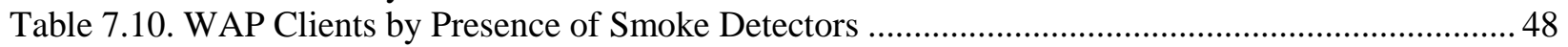

Table 7.11. Summary of WAP Household Health and Safety Findings ................................................ 49

Table 8.1. WAP Clients By Level of Difficulty Faced Paying Energy Bills ............................................. 52

Table 8.2. WAP Clients by How Often Household Did Not Pay Energy Bills to Pay Other Utility

Bills in Past 12 Months ...................................................................................................... 52

Table 8.3. WAP Clients by How Often Household Did Not Pay Energy Bills in Order to Purchase

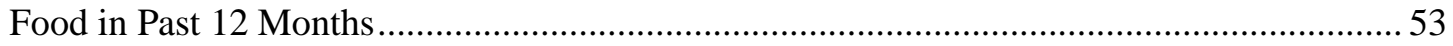

Table 8.4. WAP Clients by How Often Household Did Not Pay Energy Bills to Purchase

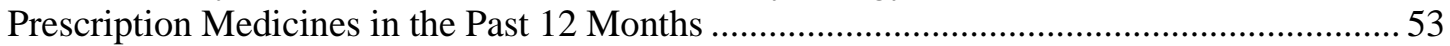

Table 8.5. WAP Clients by Whether Household Used a Budget Plan in Past 12 Months ......................... 54

Table 8.6. WAP Clients by How Often Household Paid Less Than Full Energy Bill Because They Were Unable to Afford Whole Energy Bill in Past 12 Months ................................................ 54

Table 8.7. WAP Clients By How Often Received Disconnect Notice in the Past 12 Months.................... 55

Table 8.8. Percent of WAP Clients Who Used Short-Term, High Interest Loans to Pay ........................... 55

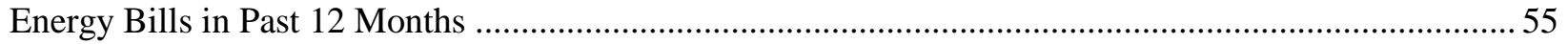

Table 8.9. WAP Clients by How Frequently Household Did Not Pay Other Utility Bills in Order to

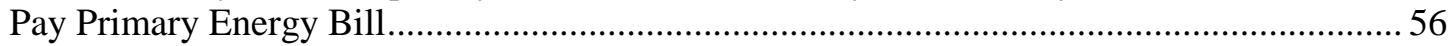

Table 8.10. Percent of WAP Clients Who Faced Food Concerns in Past 4 Weeks ................................... 56

Table 8.11. WAP Clients by How Frequently Household Did Not Purchase Food in Past 12 Months

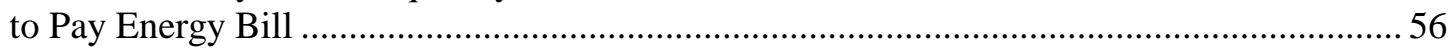

Table 8.12. WAP Clients by How Frequently Household Did Not Fill Prescriptions in Past 12

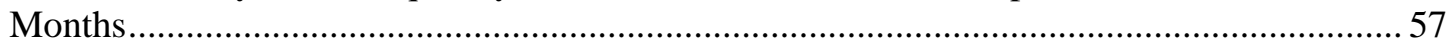

Table 8.13. WAP Clients by Service Termination in the Past 12 Months ...............................................5 57

Table 8.14. WAP Clients by Whether a Fire Resulted from an Alternative ..........................................58

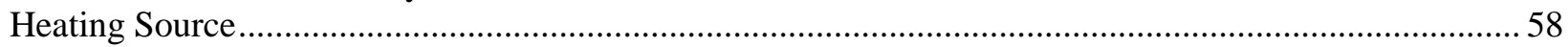

Table 8.15. WAP Clients by Whether Household Moved Because Could Not Pay Energy Bills in the Past 5 Years .......................................................................................................... 58

Table 8.16. Percent of WAP Households That Experienced Major Disruptions As a Result of

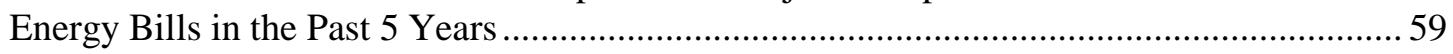

Table 8.17. Summary of Findings on WAP Household Bill Payment Problems.......................................59

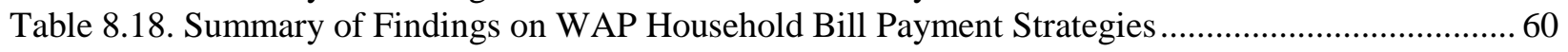

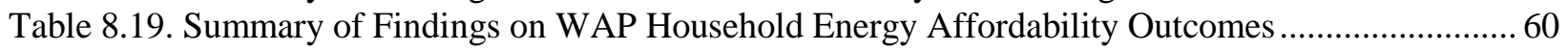

Table 9.1. WAP Clients by Whether Had Health Insurance Coverage in the Past 12 Months.................. 62

Table 9.2. WAP Clients by Health Insurance Coverage in the Past 12 Months ........................................ 62

Table 9.3. Percent of WAP Clients Who Have a Health Plan That Covers Prescriptions ......................... 62

Table 9.4. Percent of WAP Households That Could Not Afford to See Doctor in Past 12 Months,

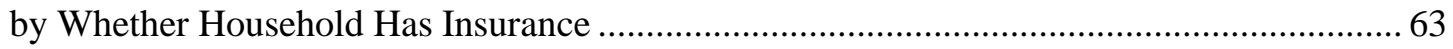

Table 9.5. Percent of WAP Households That Had Problems Paying Medical Bills in Past 12 Months ..... 63

Table 9.6. Percent of WAP Households That Needed Prescription Medicines, But Couldn't Afford to Buy Them in Past 12 Months, by Whether Prescriptions Are Covered under Insurance

Table 9.7. How Frequently WAP Clients Needed Prescription Medicine, But Used Money to Pay Utility Bill by Whether Household Gets Prescriptions Covered under Insurance ................... 64

Table 9.8. Number of Days WAP Survey Respondent Had Poor Physical or Mental.............................. 65

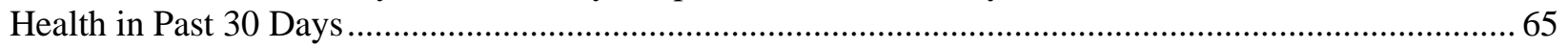

Table 9.9. Number of Days WAP Survey Respondent Got Enough Sleep in the Past 30 Days................ 65

Table 9.10. Number of Days WAP Survey Respondent Faced Changes in Ability to Do Work ............... 66

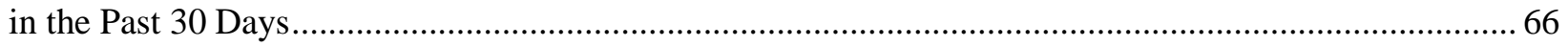

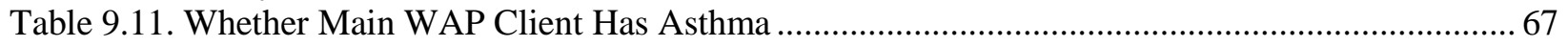

Table 9.12. When WAP Clients Experienced Most Recent Asthma Symptoms ...................................... 67 
Table 9.13. Percent of WAP Clients Who Faced Medical Emergencies Due to Asthma in the Past 12 Months.

Table 9.14. Work Missed By Primary Wage Earner Due to Illness or Injury in WAP Households in the Past 12 Months 68

Table 9.15. Work Missed By Primary Wage Earner Due to Illness or Injury of Another Person in WAP Households in the Past 12 Months 68

Table 9.16. Presence of Health Issues in WAP Households in the Past Three Months 69

Table 9.17. Incidence of Lead Poisoning in WAP Households in the Past 12 Months ...............

Table 9.18. Percent of Medical Issues in WAP Households in Past 12 Months .70

Table 9.19. Percent of WAP Clients Who Experienced Illness or Injury in the Past 12 Months 71

Table 9.20. Percent of School Missed By School-Aged Child Due to Illness or Injury in the Past 12 Months in a WAP Household 71

Table 9.21. Summary of Select Findings on Health Insurance Coverage and Difficulty Paying Medical Costs 72

Table 9 22. Summary of Select Findings on Health Status and Outcomes. 72 


\section{ACRONYMS AND ABBREVIATIONS}

$\begin{array}{ll}\text { AC } & \text { Air Conditioning } \\ \text { CDD } & \text { Cooling Degree Days } \\ \text { CFL } & \text { Compact Fluorescent Light } \\ \text { CFM50 } & \text { Cubic Feet per Minute @ 50 pascals } \\ \text { CFR } & \text { Code of Federal Regulations } \\ \text { CO } & \text { Carbon Monoxide } \\ \text { DOE } & \text { Department of Energy } \\ \text { ECM } & \text { Energy Conservation Measure } \\ \text { ECW } & \text { Energy Center of Wisconsin } \\ \text { HDD } & \text { Heating Degree Days } \\ \text { IAQ } & \text { Indoor Air Quality } \\ \text { KWH } & \text { Kilowatt Hour } \\ \text { ORNL } & \text { Oak Ridge National Laboratory } \\ \text { OWIP } & \text { Office of Weatherization and Intergovernmental Programs } \\ \text { PY } & \text { Program Year } \\ \text { RX } & \text { Prescription Medications } \\ \text { SOW } & \text { Scope of Work } \\ \text { SSE } & \text { Steady State Efficiency } \\ \text { THERM } & \text { British Thermal Units } \\ \text { WAP } & \text { Weatherization Assistance Program }\end{array}$





\section{ACKNOWLEDGEMENTS}

The work presented in this report was funded by the U.S. Department of Energy's (DOE) Office of Weatherization and Intergovernmental Programs (OWIP).

This report summarizes the findings from the Baseline Occupant Survey of the Weatherization Assistance Program (WAP) Evaluation. In this study, the evaluation team obtained lists of clients from 220 local weatherization agencies in all 50 states and the District of Columbia and conducted surveys with 1,897 WAP clients.

The original design for the survey was developed by staff from the Oak Ridge National Laboratory (ORNL) as one component of the National Evaluation of the Weatherization Assistance Program. (National Evaluation of the Weatherization Assistance Program: Preliminary Evaluation Plan for Program 2006 - ORNL/CON-498). As part of the evaluation plan development the design team consulted with and received feedback the Network Planning Committee, 41 individuals from the weatherization network. Erin Rose of ORNL developed the final version of the survey instrument.

ORNL contracted with the research team of APPRISE Incorporated, the Energy Center of Wisconsin, Michael Blasnik and Associates, and Dalhoff Associates LLC to conduct the National Evaluation. APPRISE took primary responsibility for the design and implementation of this study. The members of the Evaluation Team who contributed to the design and implementation of this survey included:

APPRISE Incorporated

Jackie Berger

David Carroll

Colleen Driscoll

Jennifer Frenett

Ferit Ucar

Anne Worth

\author{
The Energy Center of Wisconsin \\ Claire Cowan \\ LaShanta Goodwin \\ Jaimie Rule
}

Carolyn Miller Consulting

Carolyn Miller

Braun Research prepared the computer assisted telephone interview (CATI) (survey instrument), conducted the telephone interviews, and delivered a data file for this study.

This study could only be completed with the cooperation and contributions of the 51 grantees and 220 subgrantees who furnished lists of clients. In addition, the study depended on the willingness of 1,897 clients to share their experiences with the evaluation team.

Finally, we would like to acknowledge the assistance and guidance of ORNL project managers, DOE Project Officers, and DOE Headquarters Staff.

Jackie Berger

David Carroll 



\section{EXECUTIVE SUMMARY}

The purpose of this report is to disseminate the findings from an analysis of the Baseline Occupant Survey. This survey was conducted with two groups of clients, one group that was scheduled for a Weatherization Assistance Program (WAP) audit in PY 2011 and a second group that had been served by the program one year earlier. The primary focus of the Baseline Occupant Survey was to develop a better understanding of the pre-weatherization experiences of clients served by the program in PY 2011. ${ }^{1}$ The survey collected a comprehensive set of data that characterized client households and homes, developed information on the energy-related performance of clients' homes, documented the rate at which clients reported having energy affordability problems, gathered information for indicators that are correlated with indoor air quality (IAQ) problems, and measured the incidence of health-related problems experienced by clients that may be related to the quality of their housing units. Since the survey also interviewed clients served in PY 2010, the Baseline Survey also supports analysis of how the program applicants compare, on all of the topics outlined above, to clients who have had the benefit of program services for one year.

\section{Background}

The U.S. Department of Energy's (DOE) Weatherization Assistance Program was created by Congress in 1976 under Title IV of the Energy Conservation and Production Act. The purpose and scope of the Program as currently stated in the Code of Federal Regulations (CFR) 10CRF 440.1 is "to increase the energy efficiency of dwellings owned or occupied by low-income persons, reduce their total residential energy expenditures, and improve their health and safety, especially low-income persons who are particularly vulnerable such as the elderly, persons with disabilities, families with children, high residential energy users, and households with high energy burden." (Code of Federal Regulations, 2011)

At the request of DOE, Oak Ridge National Laboratory (ORNL) developed a comprehensive plan for a national evaluation of WAP that was published in 2007. DOE furnished funding to ORNL in 2009 for a national evaluation for Program Years 2007 and 2008, with a particular emphasis on PY 2008. The Scope of Work (SOW) for the evaluation includes an Impact Assessment, a Process Assessment, Special Technical Studies, and a Synthesis Report. The Occupant Surveys contribute to both the Impact and Process Assessments.

\section{Occupant Study Overview}

The Baseline Occupant Survey is one of three surveys that are planned to be conducted with the selected WAP clients. The Baseline Occupant Survey collects information for clients prior to weatherization. The Client Satisfaction Survey collects information on client perceptions of WAP service delivery. The follow-up Occupant Survey directly assesses household budget and energy behaviors pre- to postweatherization. This is one of several reports that will be completed using findings from the Occupant Surveys. The full set of reports includes:

- Baseline Occupant Survey Report: Assessment of Client Status and Needs (Carroll, et al. 2014)

- Client Satisfaction Survey Report: WAP Service Delivery from the Client's Perspective (Carroll, et al. 2014)

- Survey of Recipients of Weatherization Assistance Program Services: Assessment of Household Budget and Energy Behaviors Pre- to Post-Weatherization (Tonn, et al. 2015)

- Health and Household Related Benefits Attributable to WAP (Tonn, et al. 2014)

\footnotetext{
${ }^{1}$ The target analysis year of the evaluation was PY 2008, but the evaluation project was not funded until 2009 and OMB clearance for data collection was not granted until 2010. As a result, the Occupant Survey was not conducted until 2011.
} 
- Exploratory Review of State, Agency and Client Experiences with Deferred Services Under the Weatherization Assistance Program (Rose, et al. 2014)

One important purpose of the Occupant Surveys is to measure and quantify the non-energy benefits associated with WAP by directly observing the changes in the status of low-income households that received WAP services. The findings from these surveys contribute to the development of the WAP Impact Evaluation. The Client Satisfaction Survey Report and the Deferral Report also contribute to the WAP Process Evaluation.

\section{Baseline Occupant Survey Methodology}

In PY 2008 DOE furnished WAP funding to grantees that then distributed funds to over 900 subgrantees. The Evaluation Team selected a sample of 220 subgrantees and requested client lists in the summer of 2011: one list of clients who had been income-qualified for WAP and were scheduled for a home energy audit (i.e., treatment group) and a second list of clients who had received weatherization services during PY 2010 (i.e., comparison group). The target lists included households in single family site built homes, mobile homes, and small multifamily buildings. Interviews were conducted with 1,094 clients from the treatment group and with 803 clients from the comparison group. Subsequently it was determined that 665 treatment group clients had received WAP services, continued to live in the weatherized housing unit, and could be contacted for interview. The tables in this report compare statistics for those 665 treatment group clients with the 803 comparison group clients.

\section{WAP Client Household and Housing Unit Characteristics}

The Baseline Survey showed that low-income households receiving WAP services are diverse and include all types of low-income households and individuals. ${ }^{2}$

- Elderly households are a priority group for the program. The survey found that 47 percent of households have an elderly member; 25 percent are an elderly individual, eight percent are an elderly couple, and 13 percent have both an elderly individual and other household members that are not elderly

- Households with children are a priority group for the program. The survey found that 36 percent of households have at least one child in the home, 19 percent are two parent families, and 17 percent are single parent families.

- The program serves clients of all races and ethnicities; the survey found that 73 percent of clients had a white non-Hispanic head of household, 15 percent were black non-Hispanic, eight percent were Hispanic, and four percent were other racial/ethnic groups.

- The program serves clients at all different levels of education; the survey found that 20 percent had less than a high school degree, 40 percent had a high school diploma, and 40 percent had at least some college.

- The survey also showed that WAP clients represent all different types of economic circumstances. Many WAP households have one or more individuals in the labor force; 24 percent are employed full-time, 11 percent are employed part-time, and seven percent are

\footnotetext{
${ }^{2}$ The survey had a question about whether the head of household was unable to work because of a disability, but did not include questions on the disability status of all individuals in the household. It is not possible to report on the number of households with a disabled individual.
} 
unemployed but looking for work. Of the WAP households that do not have an individual in the labor force, 30 percent are retired, 25 percent are persons with disabilities, and only three percent identify as homemakers or students.

These statistics show that there is no one group or set of characteristics that typify WAP clients. Service delivery agencies adapt service delivery to each household as they learn about that household's specific circumstances.

Most of the clients responding to the Baseline Survey were homeowners. Even among low-income households, most households that live in single family site built and single family mobile homes are owners (occupants of large multifamily dwellings were excluded from this study). Since WAP participation requires building owner permission and may require an owner contribution, serving tenants requires additional administrative work on the part of agencies. In this sample 87 percent of the households reported that they are owners.

The Baseline Survey showed that WAP client housing units are as diverse as WAP client households. Findings include:

- Weatherization measures have to be adapted for the housing unit's foundation type; 65 percent of homes had a basement, 15 percent had a crawl space, and 20 percent were on a concrete slab.

- Other housing configuration factors also affect weatherization procedures; 53 percent of clients had a full attic and 23 percent had an attached garage.

- The type of heating fuel and equipment also affects the weatherization audit procedures and potential measures; 82 percent of households had combustion equipment (i.e., burned natural gas, propane, fuel oil, or wood) while 18 percent had electric equipment.

- About 85 percent of households had air conditioning equipment, but only about one-half of those reported having central equipment with ducts that would be affected by duct sealing measures.

In each service delivery agency's area there may be more commonality among the homes to which they deliver services. However, agency staff is likely to be asked to address each different type of housing unit configuration in their service delivery area.

\section{WAP Client Heating System Status and Performance}

The Baseline Occupant Survey furnished detailed information on the fuels and equipment that WAP clients use to heat their homes, as well as in-depth information on the status and performance of WAP client heating systems. Some key findings include:

- Heating Equipment - About seven percent of WAP clients report that their main heating equipment is portable heaters, cooking stoves, heating stoves, or fireplaces. Those systems usually are inadequate to furnish consistent heating throughout the home and sometimes present risks to household members.

- Supplemental Heating Equipment - Almost one-half of clients report using supplemental heating equipment, either to reduce the cost of home heating or because the heating distribution system is inadequate. Frequencies related to risks associated with this equipment included: 
○ 6.5 percent burned poor quality materials in their wood stove that might cause IAQ problems.

○ 3.6 percent used a cooking stove to provide heat; this practice can result in fires or IAQ problems.

○ 35 percent used a portable heater to provide heat; this practice can result in fires or burns.

- Broken Heating Equipment - 15 percent of WAP clients reported that they were unable to use their main heating equipment at some point in the last year because it was broken.

- Home Comfort and Draftiness - The Baseline Survey found than 39 percent of clients reported their home was cold or very cold, and 29 percent reported that their home was drafty most or all of the time in the winter. There was a high correlation between reports of a cold or very cold home and reports of a home that was drafty most or all of the time.

- Unsafe Temperatures - About 10 percent of WAP clients reported that their home was kept at a temperature that they considered to be unhealthy or unsafe three months or more during the year, and 3.2 percent of WAP clients reported that someone in their home needed medical attention because the home was too cold.

Comparison group households reported on their home heating experience for the year following weatherization. Some key differences between treatment group and comparison group households are shown in Table 1 . These findings show that WAP may have been effective in reducing, but not eliminating, these problems for low-income households.

Table 1. Summary of WAP Household Heating System Findings

\begin{tabular}{|c|c|c|c|}
\hline Indicator & Treatment & Comparison & $\begin{array}{c}\text { Percent } \\
\text { Difference }\end{array}$ \\
\hline Poor Quality Materials Burned & $6.5 \%$ & $2.6 \%$ & $-60 \%$ \\
\hline Use Cooking Stove for Heat & $3.6 \%$ & $1.5 \%$ & $-58 \%$ \\
\hline Use Portable Heater & $36 \%$ & $28 \%$ & $-22 \%$ \\
\hline Heating System Broken & $15 \%$ & $8 \%$ & $-47 \%$ \\
\hline Home Drafty Most or All of the Time & $29 \%$ & $9 \%$ & $-69 \%$ \\
\hline Home Cold or Very Cold & $39 \%$ & $20 \%$ & $-49 \%$ \\
\hline Home Kept at Unsafe Temperature & $10 \%$ & $5 \%$ & $-50 \%$ \\
\hline Medical Attention Needed & $3.2 \%$ & $2.1 \%$ & $-35 \%$ \\
\hline
\end{tabular}

\section{WAP Client Cooling System Status and Performance}

The Baseline Occupant Survey furnished detailed information on the equipment that WAP clients use to cool their homes, as well as in-depth information on the status and performance of WAP client cooling systems. Some key findings in terms of the needs of WAP clients include:

- Cooling Equipment - 74 percent of WAP clients report having and using home cooling systems; 16 percent report that they do not have home cooling systems.

- Cooling Strategies - Many WAP clients report that they employ supplemental strategies to keep their homes cool. For example, 37 percent use fans to assist with cross-ventilation, 89 percent close blinds and drapes, and 54 percent have large trees that block the sun. 
- Broken Cooling Equipment - 15 percent of WAP clients reported that they were unable to use their main cooling equipment at some point in the last year because it was broken.

- Home Comfort - 41 percent of WAP clients reported that their home was hot or very hot in the summer.

- Unsafe Temperatures - About 10 percent of WAP clients reported that their home was kept at a temperature that they considered to be unhealthy or unsafe three months or more during the year and 2.4 percent of WAP clients reported that someone in their home needed medical attention because the home was too hot.

Comparison group households reported on their home cooling experience for the year following weatherization. Some key differences between treatment group and comparison group households are shown in Table 2. These findings show that the WAP may have been effective in reducing, but not eliminating, these problems for low-income households.

Table 2. Summary of WAP Household Cooling System Findings

\begin{tabular}{|c|c|c|c|}
\hline Indicator & Treatment & Comparison & $\begin{array}{c}\text { Percent } \\
\text { Difference }\end{array}$ \\
\hline Have cooling system & $74 \%$ & $79 \%$ & $+7 \%$ \\
\hline Use cross ventilation & $37 \%$ & $36 \%$ & $-3 \%$ \\
\hline Close Blinds/Drapes & $89 \%$ & $90 \%$ & $+1 \%$ \\
\hline Cooling System Broken & $15 \%$ & $8 \%$ & $-47 \%$ \\
\hline Home Kept at Unsafe Temperature & $10 \%$ & $5 \%$ & $-50 \%$ \\
\hline Medical Attention Needed & $2.4 \%$ & $1.1 \%$ & $-55 \%$ \\
\hline
\end{tabular}

\section{Other Energy Efficiency Opportunities}

While weatherization services often focus on reducing usage for home heating and home cooling, the program can also assist the client by improving lighting practices and equipment, improving hot water practices and equipment, and capitalizing on other energy efficiency opportunities.

The Baseline Occupant Survey found that many treatment group households could improve their energy efficiency practices and thereby reduce energy consumption. Many households already use CFLs, recycle them properly, purchase Energy Star appliances, and wash and rinse their clothes in cold water. However, since some clients have not yet adopted these practices, it is possible that furnishing additional information to WAP clients as part of the delivery of weatherization services might help them to improve their energy efficiency practices and reduce usage.

\section{IAQ Risks}

There are many potential sources of IAQ problems for low-income households. Among these are: excess moisture that results in mold or mildew in the home, intrusion of pollens and other contaminants from outside the home, and having insects or rodents in the home. (The presence of rodents and insects has been shown to trigger asthma symptoms.) While many of these contaminants are difficult to measure, survey responses from treatment and comparison group clients furnish some indication of their prevalence. 
Table 3 summarizes the rate at which the treatment group households reported the presence of these risks and the difference in the rates at which treatment and comparison group households reported these risks. For example, 30 percent of treatment group households say that their home often had a mildew or musty smell. The delivery of WAP services can help to mitigate these problems by reducing the intrusion of water into the home and by installing proper ventilation in bathrooms and kitchens. The comparison group households reported a much lower incidence of the risks than did the treatment group. However, even after service delivery, some problems are still found at quite high rates. For example, 16 percent of Comparison Group households reported that their home had a mildew or musty smell and 19 percent reported seeing mold in their homes. These findings show that the WAP may have been effective in reducing, but not eliminating, these problems for low-income households.

Table 3. Summary of Findings for Indoor Air Quality Risks of WAP Households

\begin{tabular}{|l|c|c|c||}
\hline \hline Indicator & Treatment & Comparison & $\begin{array}{c}\text { Percent } \\
\text { Difference }\end{array}$ \\
\hline \hline Outdoor Noise / A great deal & $28 \%$ & $12 \%$ & $-57 \%$ \\
\hline Very or extremely infested / Insects & $5.0 \%$ & $2.2 \%$ & $-56 \%$ \\
\hline Very or extremely infested / Rodents & $1.7 \%$ & $0.6 \%$ & $-65 \%$ \\
\hline Standing Water / Often or always & $5.3 \%$ & $3.0 \%$ & $-43 \%$ \\
\hline Mildew or Musty Smell & $30 \%$ & $16 \%$ & $-47 \%$ \\
\hline Mold & $28 \%$ & $19 \%$ & $-32 \%$ \\
\hline
\end{tabular}

\section{Energy Affordability}

For many low income households energy bills can represent a significant share of income, particularly in the winter when home heating needs are the greatest and in the summer when home cooling needs are the greatest. By reducing the consumption of energy, WAP can make energy bills more affordable and potentially improve the ability of clients to maintain energy service. The analysis of the Baseline Occupant Survey shows that most WAP clients have difficulty paying their energy bills, many clients adopt strategies to pay those bills that can put household members at risk, and some clients experience significant financial and personal hardship resulting from energy affordability problems.

Table 4 summarizes the difference in the rates at which treatment and comparison group households reported energy affordability problems; both treatment group and comparison group households reported that their energy bills were hard to pay and that they sometimes were unable to pay their energy bills as a result of needing to pay for other utilities, food, or prescriptions. However, comparison group households reported problems at a rate that was about 20 percent less than the treatment group households.

Table 4. Summary of Findings on WAP Household Bill Payment Problems

\begin{tabular}{|c|c|c|c|}
\hline Affordability Problem & Treatment & Comparison & $\begin{array}{c}\text { Percent } \\
\text { Difference }\end{array}$ \\
\hline Bill Hard or Very Hard to Pay & $75 \%$ & $60 \%$ & $-20 \%$ \\
\hline Needed to Pay Other Utility Bills & $35 \%$ & $25 \%$ & $-29 \%$ \\
\hline Needed to Purchase Food & $28 \%$ & $19 \%$ & $-32 \%$ \\
\hline Needed to Purchase Prescriptions & $12 \%$ & $10 \%$ & $-17 \%$ \\
\hline
\end{tabular}

Table 5 shows that both treatment group and comparison group households reported that they needed to adopt strategies to pay their energy bills that could result in either energy service termination or a reduction in the purchase of basic necessities for the household. Comparison group households reported 
problems at a rate that was less than for treatment group households; about 30 percent fewer comparison group households reported that they had to put off paying other utility bills, food, or prescription.

Table 5. Summary of Findings on WAP Household Bill Payment Strategies

\begin{tabular}{|c|c|c|c|}
\hline Affordability Problem & Treatment & Comparison & $\begin{array}{c}\text { Percent } \\
\text { Difference }\end{array}$ \\
\hline Got a Shutoff Notice & $39 \%$ & $33 \%$ & $-15 \%$ \\
\hline Used Short Term, High Interest Loan & $19 \%$ & $12 \%$ & $-37 \%$ \\
\hline Put Off Paying Other Utility Bills & $36 \%$ & $26 \%$ & $-28 \%$ \\
\hline Did Not Purchase Food & $33 \%$ & $23 \%$ & $-30 \%$ \\
\hline Did Not Purchase Prescriptions & $27 \%$ & $19 \%$ & $-30 \%$ \\
\hline
\end{tabular}

Table 6 shows that both treatment group and comparison group households reported that energy affordability problems resulted in serious disruptions for the household. The comparison group was less likely to have experienced these problems in the preceding 12 months than the treatment group.

Table 6. Summary of Findings on WAP Household Energy Affordability Outcomes

\begin{tabular}{|c|c|c|c|}
\hline Affordability Problem & Treatment & Comparison & $\begin{array}{c}\text { Percent } \\
\text { Difference } \\
\end{array}$ \\
\hline Service Disruption & $13 \%$ & $9 \%$ & $-31 \%$ \\
\hline Fire / Alternative Heating Source & $1.1 \%$ & $0.8 \%$ & $-27 \%$ \\
\hline
\end{tabular}

The data in Tables 4, 5, and 6 suggest that WAP was effective in reducing, but not eliminating, energy affordability problems. The comparison group households (post-weatherization) had lower incidence rates for all of the identified affordability problems than did the WAP clients who were about to receive services.

\section{Health Status and Outcomes}

The Baseline Occupant Survey included a series of questions on health insurance, utilization of medical services, health status, and health outcomes for treatment and comparison group households. The analysis found that treatment and comparison group households were similar in many respects, but that there were a few important differences that may be the result of participation in WAP. Those differences will be explored in depth by comparing the findings of the Baseline Occupant Survey to those of the Follow-Up Occupant Survey.

Table 7 furnishes summary information on findings related to health insurance and payment of medical bills. Most treatment group households ( 85 percent) reported that they had health insurance; this is likely a combined result of access to employer health benefits, Medicare, Medicaid, and state supplemental health programs. However, households both with and without health insurance reported that there were times when they could not afford to get medical care and/or to purchase needed medicines and prescriptions. Moreover, most households that reported that they could not afford health care cited high energy bills as one of the barriers. In general, comparison group households were less likely to report that they could not pay for health services and were less likely to report that high energy bills were one source of difficulty in paying for services. 
Table 7. Summary of Select Findings on Health Insurance Coverage and Difficulty Paying Medical Costs

\begin{tabular}{|l||c||c||c||}
\hline \hline Medical Costs Problem & Treatment & Comparison & Percent Difference \\
\hline \hline Health care coverage available & $85 \%$ & $88 \%$ & $+3 \%$ \\
\hline \hline Have coverage but deferred treatment due to cost & $19 \%$ & $15 \%$ & $-21 \%$ \\
\hline \hline No coverage, deferred treatment due to cost & $81 \%$ & $85 \%$ & $+4 \%$ \\
\hline \hline Difficulty paying medical bills & $41 \%$ & $34 \%$ & $-17 \%$ \\
\hline \hline Difficulty paying prescription costs, Rx coverage & $29 \%$ & $22 \%$ & $-24 \%$ \\
\hline Difficulty paying prescription costs, no Rx coverage & $46 \%$ & $32 \%$ & $-30 \%$ \\
\hline \hline Deferred prescriptions to cover utility costs, Rx covered & $13 \%$ & $10 \%$ & $-23 \%$ \\
\hline \hline Deferred prescriptions to cover utility costs, Rx not covered & $23 \%$ & $12 \%$ & $-48 \%$ \\
\hline \hline
\end{tabular}

Table 8 furnishes summary information on findings related to the health status and health outcomes for treatment and comparison group clients. Treatment group households were more likely to report having poor physical health than comparison group households. Treatment group households with asthma reported having an overnight stay in the hospital at a higher rate than comparison group households. Treatment group households also had a higher average number of days missed due to the illness or injury of others in the household, and children in treatment group households were more likely to miss six or more days of school.

Table 8. Summary of Select Findings on Health Status and Outcomes

\begin{tabular}{|c|c|c|c|}
\hline Health Status Indicator & Treatment & Comparison & $\begin{array}{c}\text { Percent } \\
\text { Difference }\end{array}$ \\
\hline Poor physical health $15+$ days per month & $31 \%$ & $23 \%$ & $-25 \%$ \\
\hline Poor mental health $15+$ days per month & $20 \%$ & $19 \%$ & $-5 \%$ \\
\hline Incidence of Asthma & $14 \%$ & $15 \%$ & $+7 \%$ \\
\hline Asthma Symptoms within preceding 12 weeks & $71 \%$ & $71 \%$ & $\mathrm{NC}$ \\
\hline Households with overnight hospital stay for asthma & $13 \%$ & $8 \%$ & $-39 \%$ \\
\hline Households with emergency room visit for asthma & $16 \%$ & $19 \%$ & $+19 \%$ \\
\hline $\begin{array}{l}\text { Households missing work due to illness or injury } \\
\text { (respondent does not have asthma) }\end{array}$ & 4.41 days & 5.56 days & $+26 \%$ \\
\hline $\begin{array}{l}\text { Households missing work due to illness or injury } \\
\text { (respondent has asthma) }\end{array}$ & 16.00 days & 8.42 days & $-48 \%$ \\
\hline $\begin{array}{l}\text { Households missing work due to illness or injury of others } \\
\text { in the household (among those working) }\end{array}$ & 1.86 days & 1.33 days & $-29 \%$ \\
\hline $\begin{array}{l}\text { Households with children who missed } 6 \text { or more school } \\
\text { days due to illness or injury }\end{array}$ & $39 \%$ & $35 \%$ & $-10 \%$ \\
\hline
\end{tabular}

The data in Tables 7 and 8 suggest that WAP may have been effective in reducing, but not eliminating health issues for WAP client households. The comparison group households (post-weatherization) had lower incidence rates for some of the identified health status indicators and outcomes. However, since there are some differences in the demographic make-up of the treatment and comparison group households, the pre/post analysis of treatment group households developed by comparing findings from the Baseline Occupant Survey to the Follow-Up Occupant Survey will furnish better indicators of program impacts. 


\section{INTRODUCTION}

The purpose of this report is to disseminate the findings from an analysis of the Baseline Occupant Survey. This survey was conducted with two groups of clients, one group that was scheduled for a WAP audit in PY 2011 and a second group that had been served by the program one year earlier. The primary focus of the Baseline Occupant Survey was to develop a better understanding of the pre-weatherization experiences of clients served by the program in PY 2011. ${ }^{3}$ The survey collected a comprehensive set of data that characterized client households and homes, developed information on the energy-related performance of clients' homes, documented the rate at which clients reported having energy affordability problems, gathered information for indicators that are correlated with IAQ problems, and measured the incidence of health-related problems experienced by clients who may be related to the quality of their housing units. Since the survey also interviewed clients served in PY 2010, the Baseline Survey also supports analysis of how the program applicants compare, on all of the topics outlined above, to clients who have had the benefit of program services for one year.

The Baseline Occupant Survey is one of three surveys that are planned to be conducted with WAP clients. The Baseline Survey documents status and needs of clients prior to weatherization. The Satisfaction Survey collects information on client perceptions of WAP service delivery. The Follow-Up Survey directly measures how the status and needs of clients have changed one year after receiving WAP services.

This is one of four reports that will be completed using the Occupant Surveys. The full set of reports includes:

- Baseline Occupant Survey Report: Assessment of Client Status and Needs

- Client Satisfaction Survey Report: WAP Service Delivery from the Client's Perspective

- Follow-Up Occupant Survey Report: Comparing Pre and Post-Weatherization Status and Needs

- Deferral Report: Status and Needs of WAP Clients Deferred by WAP

One important purpose of the Occupant Surveys is to measure and quantify the nonenergy benefits associated with WAP by directly observing the changes in the status and needs of low-income households that received WAP services. The findings on nonenergy benefits from these surveys will contribute to the development of WAP Impact Report.

\subsection{NATIONAL WEATHERIZATION ASSISTANCE PROGRAM EVALUATION OVERVIEW}

The U.S. Department of Energy's (DOE) Weatherization Assistance Program was created by Congress in 1976 under Title IV of the Energy Conservation and Production Act. The purpose and scope of the Program as currently stated in the Code of Federal Regulations (CFR) 10CRF 440.1 is "to increase the energy efficiency of dwellings owned or occupied by low-income persons, reduce their total residential energy expenditures, and improve their health and safety, especially low-income persons who are particularly vulnerable such as the elderly, persons with disabilities, families with children, high residential energy users, and households with high energy burden." (Code of Federal Regulations, 2011)

At the request of DOE, Oak Ridge National Laboratory (ORNL) developed a comprehensive plan for a national evaluation of WAP that was published in 2007. (National Evaluation of the Weatherization

\footnotetext{
${ }^{3}$ The target analysis year of the evaluation was PY 2008, but the evaluation project was not funded until 2009 and OMB clearance for data collection was not granted until 2010. As a result, the Occupant Survey was not conducted until 2011.
} 
Assistance Program: Preliminary Evaluation Plan for Program Year 2006, February 2007) DOE furnished funding to ORNL in 2009 for a national evaluation for Program Years 2007 and 2008, with a particular emphasis on PY 2008. Although the focus of the WAP evaluation was households receiving weatherization during PY 2008, certain components of the study had to be completed as clients progressed through the weatherization process. Therefore, clients from later program years had to be used for sections of the evaluation such as this one.

ORNL subcontracted evaluation research to APPRISE Incorporated and its partners the Energy Center of Wisconsin (ECW), Michael Blasnik and Associates, and Dalhoff Associates LLC. The Scope of Work (SOW) for the evaluation includes the following components.

- Impact Assessment - Characterization of the weatherization network and the households that are income-eligible for WAP. Measurement and monetization of the energy and nonenergy impacts of the program. Assessment of the factors associated with higher levels of energy savings, cost savings, and cost-effectiveness.

- Process Assessment - Direct observation of how the weatherization network delivers services and assessment of how service delivery compares to national standards. Documentation of how weatherization staff and clients perceive service delivery.

- Special Technical Studies - Examination of the performance of the program with respect to technical issues such as air sealing, duct sealing, furnace efficiency, and refrigerators.

- Synthesis Study - Synthesis of the findings from this evaluation into a comprehensive assessment of the success of the program in meeting its goals and identification of key areas for program enhancement.

This analysis of the Occupant Surveys contributes to both the Impact Assessment and the Process Assessment.

\subsection{OCCUPANT SURVEY STUDY OVERVIEW}

The overarching objective of the Occupant Surveys is to assess the effectiveness of WAP services in meeting the needs of income-eligible households that received services. The survey topics include:

- Household and Housing Unit Characteristics

- Home Heating Fuels, Equipment, Behaviors, Needs, and Risks

- Home Cooling Equipment, Behaviors, Needs, and Risks

- Other Energy Efficiency Behaviors

- IAQ Risks

- Indicators of Energy Affordability

- Indicators of Health Status and Outcomes

The survey was conducted with a sample of households that had applied for WAP services, that were determined to be income-eligible for the program, and that were scheduled for a home energy audit during PY 2011. Since the households were interviewed prior to the home energy audit, it is expected that all client responses with respect to energy status and needs will be the client's perceptions and will not have been influenced in any way by WAP.

The primary purpose of this report is to document the status and needs of clients served by WAP. That analysis will be used to help assess how well the types of services delivered by WAP align with the needs of applicant households. However, since the survey also interviewed a sample of clients who were served 
in the prior program year (PY 2010), a comparison of the status for new clients to the status for prior year clients furnishes some evidence with respect to program impacts.

The longer term perspective for the Occupant Surveys is that they will measure WAP client impacts by comparing client responses to the Baseline Survey with responses by the same clients in a Follow-Up Survey conducted at least one year after service delivery. In addition, the Baseline and Follow-Up Survey also will be administered to a sample of clients who received program services in PY 2010. The analysis will measure the gross program impacts as change from the Baseline to the Follow-Up for new WAP clients. The analysis will measure net program impacts by comparing how changes for new WAP clients compared to changes for prior year WAP clients.

\subsection{ORGANIZATION OF THE BASELINE OCCUPANT SURVEY REPORT}

This report consists of nine sections, including:

- Section 2 - Survey Design and Implementation: Documents the sampling and data collection procedures, and compares treatment and comparison group characteristics.

- Section 3 - Household and Housing Unit Characteristics: Furnishes information on household demographics and housing unit characteristics for WAP clients.

- Section 4-Home Heating: Shows how WAP clients heat their homes, the performance of client heating systems, and the potential risks associated with client heating practices.

- Section 5-Home Cooling: Shows how WAP clients cool their homes, the performance of client cooling systems, and the potential risks associated with client cooling practices.

- Section 6 - Other Energy Efficiency Opportunities: Shows what other energy efficiency opportunities are available to clients and estimates the current adoption rate.

- Section 7 - IAQ Risks: Documents the rate at which clients report the presence of indicators that are associated with IAQ problems.

- Section 8 - Energy Affordability: Furnishes statistics on the source of energy affordability problems, the strategies used by households to deal with affordability problems, and affordability outcomes for clients.

- Section 9 - Health Status and Outcomes: Examines the status of households with respect to the availability of health insurance, the relationship between energy bills and use of health services, and the relationship between energy problems and health outcomes.

This report identifies differences between treatment group and comparison group households that represent nonenergy benefits. The ORNL report on health and household related benefits of WAP documents and monetizes the value of a selection of these benefits.

\footnotetext{
${ }^{4}$ Tonn, B., Rose, E., Hawkins, B., and Conlon, B. (2014c). Health and Household-Related Benefits Attributable to the Weatherization Assistance Program. ORNL/TM-2014/345, Oak Ridge National Laboratory, Oak Ridge, Tennessee.
} 



\section{METHODOLOGY}

The Baseline Occupant Survey is one of three surveys that are planned to be conducted with the selected WAP clients. The Baseline Survey documents status and needs of clients prior to weatherization. The Satisfaction Survey collects information on client perceptions of WAP service delivery. The Follow-Up Survey directly measures how the status and needs of clients have changed one year after receiving WAP services.

The survey procedures included the following:

- Agency Sample - A sample of 220 service delivery agencies was selected to represent the 905 WAP service agencies nationwide.

- Treatment Group Sample - Each agency was asked to furnish a list of clients who were incomequalified for the program and scheduled for WAP audit.

- Comparison Group Sample - Each agency was asked to furnish a list of clients who had received WAP services one program year earlier.

- Interviews - Sampled treatment and comparison group clients were contacted and interviewed using a survey instrument designed by the ORNL Evaluation Team.

Interviews were completed with 1,094 treatment group clients and 803 comparison group clients. The subsequent Client Satisfaction Survey determined that 665 of the treatment group clients received WAP services, continued to live in the weatherized housing unit, and could be contacted for follow-up interviews. That group of 665 households serves as the analysis population for this report because they are most comparable to the comparison group that was served in 2010 and could still can be reached for interview. Among the 1,094 treatment group clients surveyed prior to receiving a WAP audit, 290 reported that they had not received WAP services and 139 could no longer be reached by telephone.

\subsection{ANALYSIS FRAMEWORK}

The purpose of the Occupant Surveys is to furnish information on the energy status and needs of applicant households and to assess the extent to which WAP is able to address those needs. The primary analysis sample for the study is the treatment group: households that have applied for WAP, have been determined to be income qualified for the program, and were scheduled for a WAP home energy audit. This study is designed to:

- Develop an understanding of client energy status and needs prior to any significant contact with the program,

- Determine whether WAP was able to deliver services to clients who were income-eligible for the program,

- Assess client perceptions of the effectiveness of WAP in meeting their needs, and

- Measure the change in status and needs of the client household after having received WAP services.

The three surveys contribute to this analysis in the following way

- Baseline Survey - The Baseline Survey was conducted with WAP clients prior to their home energy audit. While clients may have had some engagement with WAP by applying for program services, these interviews represent, as much as possible, the needs of the applicant households prior to receiving services from WAP. 
- Service Delivery/Satisfaction Survey - The Satisfaction Survey was conducted in two rounds. The first round was conducted three months after the client's scheduled audit and asked clients whether they had received WAP services and, if so, to answer the Satisfaction Survey questions. The second round was conducted nine months after the scheduled audit; clients who had not yet received services at three months were re-contacted to determine whether services had been delivered and, if so, to answer the Satisfaction Survey questions.

- Follow-Up Survey - The Follow-Up Survey is planned to be conducted in the summer of 2013. The survey will be conducted with all treatment group households, including those that were served and those that were deferred.

The Baseline Survey documents client status and needs prior to weatherization. The Service Delivery/Satisfaction Survey documents which households were served and assesses client satisfaction with program services. The Follow-Up Survey assesses how client status and needs have changed for those clients who received WAP services, and how client status and needs have changed for clients who did not receive services.

One important component of the research design is that a comparison group of WAP clients was interviewed. The treatment group households were scheduled to receive WAP services during PY 2011. A comparison group of households that received services during PY 2010 also was sampled and interviewed. The primary purpose of the comparison group is to furnish a "difference of differences" analysis. In such a design, the gross program impact is the change in the treatment group status. But, the net program impact is determined by measuring the status change for a comparison group and netting out any change for the comparison group against the change for the treatment group to control for other unobserved factors. For example, if the treatment group had a 25 percent reduction in service terminations, but over the same time period the comparison group had a 10 percent reduction in service terminations that was a result of increased availability of LIHEAP funds, the net change in service termination levels due to the program would be estimated to be 15 percent (i.e., the observed change minus change that the treatment group might have experienced even without the program).

\subsection{BASELINE SURVEY ANALYSIS}

The primary purpose of the Baseline Survey report is to furnish statistics that document the status and needs of WAP clients prior to the receipt of program services. However, a cross-sectional analysis that compares treatment group clients to comparison group clients also furnishes valuable information on the potential impact of WAP. Both analyses are presented in this report; baseline statistics for treatment group households and analysis of similarities and differences with comparison group households.

One important pre-condition for this analysis is to ensure comparability of the treatment group and comparison group households. The treatment and comparison group households were sampled from the same agencies and interviews were conducted in the same way. However, there are certain factors that could have affected the comparability of the client groups. Tables 2.1 through 2.3 furnish some key statistics for the treatment and comparison group households that help to assess their comparability. Table 2.1 shows the distribution of clients by Climate Zone. A higher proportion of the treatment group clients were in the Cold Climate Zone; a larger proportion of comparison group households were in the Moderate and Hot Climate Zones. Similarly, Table 2.2 shows that a higher percentage of the treatment group households were in the Northeast and Midwest Census Regions, while a higher percentage of the comparison group households were in the South Census Region. In terms of demographics and housing unit characteristics, the groups are similar in most respects. However, the treatment group has a larger proportion of households with children (five percentage points) and the comparison group has a larger proportion of households with an elderly person (eight percentage points). For that reason, the 
comparative cross-sectional analysis is not viewed as being as robust as the longer-term longitudinal analysis. However, the distributions are sufficiently similar that they can be a useful leading indicator of the expected program impacts.

Table 2.1. WAP Clients by Climate Zone

\begin{tabular}{||l||c||c||}
\hline \hline Climate Zone & Treatment & Comparison \\
\hline \hline Number of Respondents & 665 & 803 \\
\hline \hline Very Cold & $26 \%$ & $26 \%$ \\
\hline Cold & $48 \%$ & $41 \%$ \\
\hline Moderate & $17 \%$ & $22 \%$ \\
\hline Hot & $9 \%$ & $11 \%$ \\
\hline \hline TOTAL & $100 \%$ & $100 \%$ \\
\hline
\end{tabular}

Table 2.2. WAP Clients by Census Region

\begin{tabular}{|l||c||c||}
\hline Census Region & Treatment & Comparison \\
\hline \hline Number of Respondents & 665 & 803 \\
\hline \hline Northeast & $29 \%$ & $25 \%$ \\
\hline Midwest & $39 \%$ & $36 \%$ \\
\hline South & $19 \%$ & $23 \%$ \\
\hline West & $13 \%$ & $15 \%$ \\
\hline \hline TOTAL & $100 \%$ & $100 \%$ \\
\hline
\end{tabular}

Table 2.3. WAP Clients by Demographics and Housing Unit Characteristics

\begin{tabular}{||l||c||c||}
\hline \hline Demographics & Treatment & Comparison \\
\hline \hline Number of Respondents & 665 & 803 \\
\hline \hline Single Family Home & $76 \%$ & $79 \%$ \\
\hline Natural Gas Main Heat & $52 \%$ & $51 \%$ \\
\hline Central Heating System & $70 \%$ & $71 \%$ \\
\hline Home Owner & $87 \%$ & $91 \%$ \\
\hline At least one Elderly Person & $47 \%$ & $55 \%$ \\
\hline At least one Child & $35 \%$ & $30 \%$ \\
\hline Employed & $34 \%$ & $32 \%$ \\
\hline \hline
\end{tabular}

\subsection{DATA COLLECTION STATISTICS}

The Baseline Occupant Survey used sample development and interviewing procedures that were designed to achieve the highest possible response rate.

The agency contacts were made by ECW case managers who have been working with service delivery agencies since 2010 to facilitate data collection for the overall evaluation project. For each sampled service delivery agency: 
- Advance Mailing - The ECW case manager mailed information to the agency contact explaining the purpose of the data collection and the procedures for selecting and delivering client lists.

- Agency Phone Contact - The ECW case manager contacted the agency contact to discuss the data collection schedule and to clarify the study procedures.

- Agency Follow-Up - The ECW case manager conducted regular follow-up with the agency contact to facilitate the development and delivery of the clients lists.

Of the 220 sampled agencies, 204 (93\%) furnished client lists. The survey was successful in getting completed interviews from 203 of the 204 agencies that furnished client lists.

The telephone interviews were conducted by Braun Research. The following contact protocol was used:

- Advance Mailing - APPRISE prepared and mailed advance letters to all sampled clients. These advance letters explained the purpose of the study, alerted the respondent that a $\$ 20$ incentive would be paid, and gave the client an 800 number that they could use to contact the phone center if they preferred.

- Contact and Screen - Braun Research made 10 contacts to all numbers, ensuring that the time of day and day of the week was properly rotated. The interviewers left messages on answering machines every third call to alert the client of the purpose of the call.

- Spanish Language Interviews - When the telephone center encountered Spanish-speaking households with a language barrier, an APPRISE interviewer re-contacted the households and conducted the interview in Spanish.

The survey contact rate was 83 percent, the cooperation rate was 88 percent, and the final response rate was 74 percent. 


\section{HOUSEHOLD AND HOUSING UNIT CHARACTERISTICS}

This section of the report provides findings from the Baseline Survey on the household and housing unit characteristics of the treatment and comparison group clients. It examines three different dimensions of the population of clients served by the program.

- Characteristics of Households and Household Members - The first part of this section presents information on household status and household members, including the number of household members and the presence of vulnerable individuals in the household.

- Head of Household Characteristics - The second part of this section presents head of household information, including age, education, employment status, and race and ethnicity.

- Housing Unit Structure - The final part of this section presents information on the configuration of WAP client housing units.

In this section, baseline information is first presented on the treatment group households (i.e., households served in PY 2011). Treatment group households are then compared to the comparison group households (i.e., households served in PY 2010).

In general, the statistics in this section show that WAP subgrantees are faced with a diverse group of households and housing units. WAP clients include elderly households, single parent families with children, two-parent families with children, and households with a disabled individual. While some WAP clients are either retired or disabled, many are employed. The housing units occupied by clients include inner city row houses, suburban single family homes, rural farmhouses, and mobile homes. This diversity of households and housing units presents important challenges to subgrantees that are asked to serve all eligible clients who apply for program services.

\subsection{HOUSEHOLD STRUCTURE}

Table 3.1 shows that WAP serves households of all sizes. Almost 40 percent of WAP client households are single person households, while over 10 percent has five or more household members. Comparison group households are similar to treatment group households.

Table 3.1. WAP Clients by Household Size

\begin{tabular}{||l|c|c||}
\hline \hline Including yourself, how many people normally live in this household? \\
\hline \hline Number of Respondents & Treatment & Comparison \\
\hline \hline 1 household member & 665 & 803 \\
\hline 2 household members & $38 \%$ & $41 \%$ \\
\hline 3 household members & $28 \%$ & $29 \%$ \\
\hline 4 household members & $12 \%$ & $12 \%$ \\
\hline 5 or more household members & $10 \%$ & $9 \%$ \\
\hline \hline TOTAL & $12 \%$ & $10 \%$ \\
\hline
\end{tabular}

Tables 3.2 and 3.3 furnish information on the presence of elderly household members and children in WAP client households. These two groups are specifically targeted by WAP because they are particularly vulnerable to the effects of inadequate heating and cooling services in the home. 
Table 3.2 shows that a significant share of WAP client households has one or more elderly individuals in the home. About one-half of treatment group households reported that a person 60 years or older was in the home and about 20 percent of households reported having a person 75 years or older. The presence of older individuals in the home might be associated with a higher incidence of health problems than might found in the general population. The comparison group has a higher incidence of elderly individuals; that might affect some comparisons between the treatment group and comparison group.

Table 3.2. Percent of WAP Households with an Elderly Person

\begin{tabular}{||l||c||c||}
\hline \hline \multicolumn{2}{|l||}{ Please give me the ... age... for each person in the household. } \\
\hline \hline & Treatment & Comparison \\
\hline \hline Number of Respondents & 662 & 797 \\
\hline \hline 60 years and older & $47 \%$ & $55 \%$ \\
\hline 75 years and older & $19 \%$ & $21 \%$ \\
\hline
\end{tabular}

Table 3.3 shows that a significant share of WAP client households has one or more children in the home. About one-third of treatment group households reported that a person 18 years or younger was in the home and about 15 percent of households reported having a person five years or younger. The presence of children in the home is important because improvement in home heating and/or home cooling might reduce the risk of illness and the associated expenses, as well as potentially improve the performance of children in school. The comparison group has a lower incidence of children in the home; that might affect some comparisons between the treatment group and comparison group.

Table 3.3. Percent of WAP Households with a Child

\begin{tabular}{||l||c||c||}
\hline \multicolumn{2}{|l||}{ Please give me the ... age... for each person in the household. } \\
\hline \hline & Treatment & Comparison \\
\hline \hline Number of Respondents & 662 & 795 \\
\hline \hline 18 years and under & $36 \%$ & $30 \%$ \\
\hline 5 years and under & $17 \%$ & $11 \%$ \\
\hline
\end{tabular}

Analysts often discuss a limited set of household types, typically focusing on two-parent households, single-parent households, households with elderly individuals, and households with other adults. The Baseline Occupant Survey shows that client households are somewhat more complex. Table 3.4 shows that about 36 percent of WAP client households have children; 14 percent have two parents with children, 11 percent have one parent with children, and 11 percent of households have children with parents and other adults in the home. About 47 percent of WAP clients have an elderly individual in the home; 25 percent are an elderly individual, eight percent are an elderly couple, and 13 percent of WAP clients have an elderly individual in a home with other nonelderly individuals. About five percent of households have an elderly person in a home with children. Only 23 percent of WAP households had neither an elderly person nor a child in the home. But, many of those households have an adult who is unable to work because of a disability. 
Table 3.4. WAP Clients by Basic Household Type

\begin{tabular}{||l|c|c||}
\hline \multicolumn{2}{||l||}{ Please give me the age [for each person in the household] and that person's relation to you. } \\
\hline \hline Number of Respondents & Treatment & Comparison \\
\hline \hline Households with Children & 662 & 795 \\
\hline Two parents + children only & $36 \%$ & $30 \%$ \\
\hline One parent + children only & $14 \%$ & $13 \%$ \\
\hline Other households with children & $11 \%$ & $8 \%$ \\
\hline Household with Elderly & $11 \%$ & $9 \%$ \\
\hline Elderly individual & $47 \%$ & $55 \%$ \\
\hline Elderly couple & $25 \%$ & $29 \%$ \\
\hline Other households with elderly & $8 \%$ & $13 \%$ \\
\hline Other Households (nonelderly adults and no children) & $13 \%$ & $13 \%$ \\
\hline Working adult & $23 \%$ & $21 \%$ \\
\hline Unemployed adult & $8 \%$ & $8 \%$ \\
\hline Adult unable to work because of disability & $4 \%$ & $3 \%$ \\
\hline \hline TOTAL & $11 \%$ & $10 \%$ \\
\hline \hline Adds to 105\% because 5\% of households have both elderly individuals and children. \\
\hline$*$ Adds to 106\% because 6\% of households have both elderly individuals and children.
\end{tabular}

Table 3.5 furnishes some additional information on households with children. About 19 percent of WAP households are two-parent families; 14 percent have two parents and children only, while five percent have two parents, children, and another adult in the home. About 17 percent of WAP households are single-parent families; 11 percent have one parent and children only, while six percent have one parent, children, and another adult in the household.

Table 3.5. WAP Clients by Family Type

\begin{tabular}{||l||c||c||}
\hline \hline \multicolumn{2}{|l||}{ Please give me the age [for each person in the household] and that person's relation to you. } \\
\hline \hline Number of Respondents & Treatment & Comparison \\
\hline \hline Two parents + children only & 662 & 795 \\
\hline Two parents + other adults + children & $5 \%$ & $13 \%$ \\
\hline One parent + children only & $11 \%$ & $4 \%$ \\
\hline One parent + other adults + children & $6 \%$ & $8 \%$ \\
\hline No children & $65 \%$ & $70 \%$ \\
\hline \hline TOTAL & $100 \%$ & $100 \%$ \\
\hline
\end{tabular}

Table 3.6 furnishes some additional information on households with elderly individuals. About 25 percent of WAP households are an elderly individual and eight percent are an elderly couple. An additional 13 percent of WAP client households have an elderly individual; one percent are elderly individuals and children only, four percent are elderly individuals in households with other adults and children, and eight percent are elderly individuals in a household with other adults. 
Table 3.6. WAP Clients by Elderly Household Composition

\begin{tabular}{|c|c|c|}
\hline \multicolumn{3}{|c|}{$\begin{array}{l}\text { Please give me the age [for each person in the household] and that person's } \\
\text { relation to you. }\end{array}$} \\
\hline \multicolumn{3}{|c|}{\begin{tabular}{|l||c||c|} 
& Treatment & Comparison
\end{tabular}} \\
\hline \multicolumn{3}{|c|}{\begin{tabular}{|l||c||c|} 
Number of Respondents & 662 & 795 \\
\end{tabular}} \\
\hline Elderly individual & $25 \%$ & $29 \%$ \\
\hline Elderly couple & $8 \%$ & $13 \%$ \\
\hline Elderly + children only & $1 \%$ & $2 \%$ \\
\hline Elderly + other adults + children & $4 \%$ & $4 \%$ \\
\hline Elderly + other adults only & $8 \%$ & $8 \%$ \\
\hline No elderly & $53 \%$ & $45 \%$ \\
\hline TOTAL & $100 \%$ & $100 \%$ \\
\hline
\end{tabular}

These statistics show that WAP service delivery professionals are asked to work with many different kinds of households and sometimes have to consider both the needs of elderly individuals and young children in the same home.

\subsection{HEAD OF HOUSEHOLD CHARACTERISTICS}

The characteristics of the head of household furnish another dimension for understanding WAP client households. Table 3.7 shows that about 43 percent of households have an elderly head of household. Comparing this statistic with Table 3.6 that shows about 47 percent of households have an elderly individual, it seems that in most WAP households with an elderly person, that individual is considered to be the head of household. In only about 6 percent of WAP households was the head of household under 30 years old. As noted previously, the comparison group of households was more likely to include an elderly individual than the treatment group; that same finding is observed for the age of the head of household.

Table 3.7. WAP Clients by Head of Household's Age

\begin{tabular}{||l||c||c||}
\hline \multicolumn{2}{||l||}{ Please give me the ...age...for each person in the household. } \\
\hline \hline & Treatment & Comparison \\
\hline \hline Number of Respondents & 664 & 798 \\
\hline \hline Less than 30 years old & $6 \%$ & $3 \%$ \\
\hline 30-44 years old & $17 \%$ & $15 \%$ \\
\hline $45-59$ years old & $33 \%$ & $31 \%$ \\
\hline $60-74$ years old & $29 \%$ & $34 \%$ \\
\hline 75 years old or more & $14 \%$ & $18 \%$ \\
\hline \hline TOTAL & $100 \%$ & $100 \%$ \\
\hline \hline
\end{tabular}

Table 3.8 shows that in about 20 percent of WAP households, the head of household had only limited education. However, over 40 percent had at least some college and about 20 percent has a degree past high school. The comparison group has much the same distribution on this variable as the treatment group. 
Table 3.8. WAP Clients by Head of Household's Education Level

\begin{tabular}{||l|c|c||}
\hline \multicolumn{2}{||l|}{ What is the highest degree or level of school you have completed? } \\
\hline \hline & Treatment & Comparison \\
\hline \hline Number of Respondents & 663 & 798 \\
\hline \hline No School & $6 \%$ & $6 \%$ \\
\hline Some School & $14 \%$ & $14 \%$ \\
\hline High School Diploma or GED & $39 \%$ & $40 \%$ \\
\hline Some College & $22 \%$ & $22 \%$ \\
\hline Associate's Degree & $11 \%$ & $8 \%$ \\
\hline Bachelor's Degree & $7 \%$ & $7 \%$ \\
\hline Advanced Degree & $2 \%$ & $2 \%$ \\
\hline \hline TOTAL & $100 \%$ & $100 \%$ \\
\hline \hline
\end{tabular}

Table 3.9 shows that for most WAP households, the head of household was married at some time. About one-third are currently married. In a little over one-half of the households, the head of household is separated from his/her spouse or has been widowed. The head of household was never married in only about 10 percent of households. Since the comparison group is, on average, older than the treatment group, the head of household also is more likely to be widowed.

Table 3.9. WAP Clients by Head of Household's Marital Status

\begin{tabular}{|c|c|c|}
\hline \multicolumn{3}{|l|}{ Are you currently ... } \\
\hline & Treatment & Comparison \\
\hline Number of Respondents & 662 & 800 \\
\hline married /a member of a couple? & $36 \%$ & $37 \%$ \\
\hline separated/divorced? & $34 \%$ & $29 \%$ \\
\hline widowed? & $19 \%$ & $24 \%$ \\
\hline never married? & $12 \%$ & $11 \%$ \\
\hline TOTAL & $100 \%$ & $100 \%$ \\
\hline
\end{tabular}

Table 3.10 shows the race and ethnicity of the head of household for WAP clients. Almost 75 percent of these clients in the Baseline Occupant Survey were white non-Hispanic. About 15 percent were black non-Hispanic and eight percent reported that they were of Hispanic origin.

Table 3.10. WAP Clients by Head of Household's Race/Ethnicity

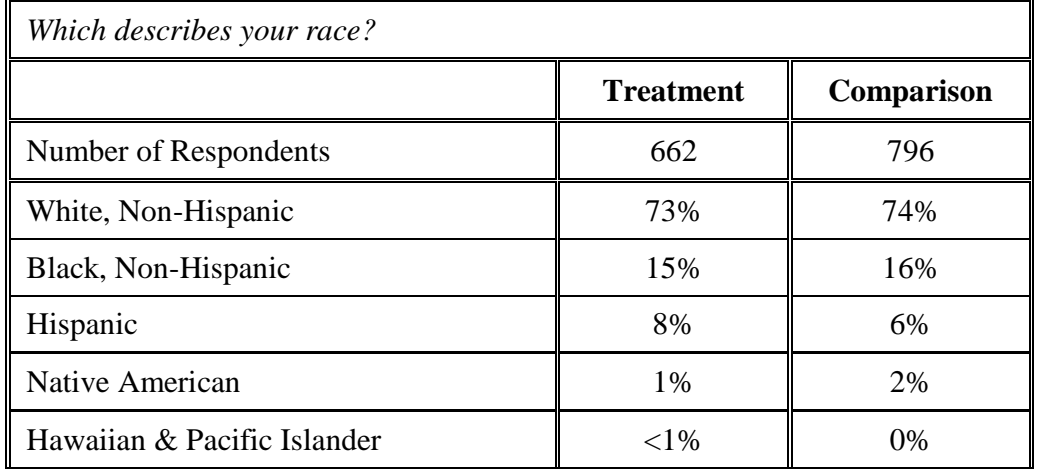




\begin{tabular}{|c|c|c|}
\hline \multicolumn{3}{|c|}{ Which describes your race? } \\
\hline & Treatment & Comparison \\
\hline Number of Respondents & 662 & 796 \\
\hline Asian & $<1 \%$ & $1 \%$ \\
\hline Other/More than one & $2 \%$ & $2 \%$ \\
\hline TOTAL & $100 \%$ & $100 \%$ \\
\hline
\end{tabular}

Table 3.11 shows that almost all WAP clients were born in the US. Only four percent of households were naturalized citizens. Less than one percent of households reported that they were undocumented resident.

Table 3.11. WAP Clients by Head of Household's Citizenship Status

\begin{tabular}{|c|c|c|}
\hline \multicolumn{3}{|c|}{$\begin{array}{l}\text { Were you born a citizen of the United States or did you become a citizen of th } \\
\text { United States through naturalization? }\end{array}$} \\
\hline & Treatment & Comparison \\
\hline Number of Respondents & 663 & 802 \\
\hline Born & $96 \%$ & $96 \%$ \\
\hline Naturalized & $4 \%$ & $3 \%$ \\
\hline Neither [Volunteered] & $<1 \%$ & $<1 \%$ \\
\hline TOTAL & $100 \%$ & $100 \%$ \\
\hline
\end{tabular}

Table 3.12 shows that in a little over one-half of the WAP client households, the head of household is either retired or unable to work because of a disability. In about one-third of the households, the head of household is employed, but 11 percent report that they are only employed part-time. About seven percent report that they are unemployed, and less than five percent report that they are students or homemakers. Table 3.13 shows that about six percent of WAP household heads have seasonal employment. Since the comparison group has a greater share of elderly households, those households are more likely to report that they are retired than the treatment group.

Table 3.12. WAP Clients by Primary Wage Earner's Employment Status

\begin{tabular}{|l||c|c||}
\hline \multicolumn{1}{|l|}{$\begin{array}{l}\text { Is the primary wage earner in the household currently...? Is the primary wage earner } \\
\text { in the household employed full-time or part-time? }\end{array}$} & Treatment & Comparison \\
\hline \hline & 663 & 802 \\
\hline \hline Number of Respondents & $24 \%$ & $24 \%$ \\
\hline Employed Full-Time & $11 \%$ & $8 \%$ \\
\hline Employed Part-Time/Other & $7 \%$ & $5 \%$ \\
\hline Unemployed & $2 \%$ & $2 \%$ \\
\hline Homemaker & $2 \%$ & $1 \%$ \\
\hline Student & $30 \%$ & $36 \%$ \\
\hline Retired & $25 \%$ & $24 \%$ \\
\hline Unable to Work & $100 \%$ & $100 \%$ \\
\hline \hline TOTAL & & \\
\hline
\end{tabular}


Table 3.13. WAP Clients by Whether Primary Wage Earner Is Employed Seasonally

\begin{tabular}{||l||c||c||}
\hline \multicolumn{1}{||l||}{ Is the primary wage earner's main job ...considered seasonal? } \\
\hline \hline Number of Respondents & Treatment & Comparison \\
\hline \hline Employed Non-Seasonal & 662 & 800 \\
\hline Employed Seasonal & $28.3 \%$ & $27.6 \%$ \\
\hline Unemployed Seasonal & $5.9 \%$ & $4.1 \%$ \\
\hline Other & $0.6 \%$ & $0.4 \%$ \\
\hline \hline TOTAL & $65.3 \%$ & $67.8 \%$ \\
\hline \hline
\end{tabular}

The head of household characteristics show a diverse population. A significant share is elderly, retired, and widowed. But, there also are married heads of households who are employed. Almost all of the interviewed household heads are citizens by birth, and almost 75 percent are white and are not of Hispanic origin.

The Eligible Population Report shows that 56 percent of low-income households are white, 17 percent are black non-Hispanic, 16 percent are Hispanic, and 11 percent are other races or ethnicities. However, most WAP funding is allocated to states in the Very Cold and Cold Climate Zones. In those areas, there are fewer low-income households that are Hispanic or other races. That is one important reason for the difference between the racial/ethnic composition of WAP households compared to all low-income households.

\subsection{HOUSING UNIT CHARACTERISTICS}

The Occupant Survey included households that live in single family site built and mobile homes, as well as households that live in small multifamily buildings (2-4 units). Table 3.14 shows that most of those housing units were single family detached units ( 70 percent) or mobile homes ( 22 percent). About six percent of households occupy single family attached homes (i.e., duplexes or row homes) and about two percent live in a small multifamily building. The housing unit type for the comparison group is similar to that of the treatment group.

Table 3.14. WAP Clients by Housing Type

\begin{tabular}{|l|c||c||}
\hline \multicolumn{2}{|l||}{ Which of the following do you believe best describes your current home? } \\
\hline \hline & Treatment & Comparison \\
\hline \hline Number of Respondents & 665 & 802 \\
\hline \hline Single family, detached & $70 \%$ & $73 \%$ \\
\hline Single family, attached & $6 \%$ & $6 \%$ \\
\hline Mobile home & $22 \%$ & $19 \%$ \\
\hline Apartment & $2 \%$ & $2 \%$ \\
\hline \hline TOTAL & $100 \%$ & $100 \%$ \\
\hline
\end{tabular}

Most WAP clients (87 percent) own their home (Table 3.15). This is consistent with the housing unit type served by WAP; over 80 percent of low-income households in single family site built and mobile homes 
are owners. (See Table 5.13 from the Eligible Population Report) The program requires landlord approval. The eligible population is 80 percent owner, but the clients served are over 87 percent owners. $^{5}$

Table 3.15. WAP Clients by Home Ownership Status

\begin{tabular}{|l|c||c||}
\hline \multicolumn{2}{|l|}{ Do you rent or own your current residence? } \\
\hline \hline & Treatment & Comparison \\
\hline \hline Number of Respondents & 663 & 803 \\
\hline \hline Own & $87 \%$ & $91 \%$ \\
\hline Rent & $13 \%$ & $9 \%$ \\
\hline Other & $<1 \%$ & $0 \%$ \\
\hline \hline TOTAL & $100 \%$ & $100 \%$ \\
\hline
\end{tabular}

About 65 percent of WAP client housing units have a basement, while 20 percent have a concrete slab foundation and 15 percent have a crawl space (Table 3.16). Since each of these foundation types involves a somewhat different set of weatherization procedures, it shows the diversity of housing stock that has to be treated. The comparison households are similar to the treatment households.

Table 3.16. WAP Clients by Home's Foundation Type

\begin{tabular}{|c|c|c|}
\hline \multicolumn{3}{|c|}{$\begin{array}{l}\text { Is any part of your home over a crawl space with exposed dirt as the floor? } \\
\text { Is any part of your home over a basement? }\end{array}$} \\
\hline & Treatment & Comparison \\
\hline Number of Respondents ${ }^{6}$ & 514 & 650 \\
\hline Basement & $65 \%$ & $62 \%$ \\
\hline Crawl Space & $15 \%$ & $14 \%$ \\
\hline Slab/Other & $20 \%$ & $24 \%$ \\
\hline TOTAL & $100 \%$ & $100 \%$ \\
\hline
\end{tabular}

Similarly, the presence of an attached garage and/or an attic can affect the weatherization procedures. If a WAP client has an attached garage, the weatherization procedure should work to ensure that contaminated air from the garage does not leak into the living space of the home. About one-fourth of WAP clients reported that they had an attached garage (Table 3.17). The presence of an attic that is used by the household also can make weatherization challenging; the weatherization crew needs to determine whether the attic should be inside or outside the thermal envelope of the home. About 53 percent of WAP clients have an attic that can be used by the household (Table 3.18). The comparison group is similar to the treatment group in terms of the presence of attached garages and attics.

\footnotetext{
${ }^{5}$ The Eligible Population Report shows that 52 percent of low-income households own their homes. However, most of the lowincome homeowners live in single family homes or mobile homes, while most of the low-income renters live in large multifamily dwellings (5+ units). This survey focused on WAP clients in single family homes, mobile homes, and small multifamily homes (2-4 units); those households represent 82 percent of WAP clients. However, while about 68 percent of low-income households in single family homes, mobile homes, and small multifamily homes are owners, 87 percent of WAP clients in those same housing unit types are owners.

${ }^{6}$ Respondents living in mobile homes were not included in the base for this table.
} 
Table 3.17. WAP Clients by Whether House Has an Attached Garage

\begin{tabular}{||l||c|c||}
\hline \hline \multicolumn{1}{|l|}{ Does your home have a garage that is attached to or part of your home? } \\
\hline \hline Number of Respondents & Treatment & Comparison \\
\hline \hline Yes & 649 & 786 \\
\hline No & $23 \%$ & $24 \%$ \\
\hline \hline TOTAL & $77 \%$ & $76 \%$ \\
\hline
\end{tabular}

Table 3.18. WAP Clients by Whether House Has an Attic

\begin{tabular}{|c|c|c|}
\hline \multicolumn{3}{|c|}{$\begin{array}{l}\text { An attic is an area directly below the roof, accessible by stairs, with space for you to stanc } \\
\text { upright and easily move about. Does your home have an attic? }\end{array}$} \\
\hline & Treatment & Comparison \\
\hline Number of Respondents ${ }^{8}$ & 509 & 644 \\
\hline Yes & $53 \%$ & $53 \%$ \\
\hline No & $47 \%$ & $47 \%$ \\
\hline TOTAL & $100 \%$ & $100 \%$ \\
\hline
\end{tabular}

The main heating fuel and the use of secondary sources of heat also have a major impact on the weatherization procedures for a housing unit. Table 3.19 shows that about 60 percent of households have natural gas or propane as their main heating fuel and that about 10 percent use fuel oil. While both gas and fuel oil furnaces are combustion appliances, their properties are somewhat different and require different types of weatherization testing and procedures. About seven percent of households also use either wood or kerosene for their main heat. Wood stoves and kerosene heaters present special challenges to weatherization teams attempting to ensure that the home is safe and efficient.

Table 3.19. Clients by Main Type of Heating Fuel

\begin{tabular}{|l|c|c||}
\hline \multicolumn{2}{|l|}{ What is the main fuel used for heating your home? } \\
\hline \hline & Treatment & Comparison \\
\hline \hline Number of Respondents & 658 & 798 \\
\hline \hline Natural Gas & $53 \%$ & $51 \%$ \\
\hline Electricity & $18 \%$ & $21 \%$ \\
\hline Propane (bottle gas) & $9 \%$ & $8 \%$ \\
\hline Fuel Oil & $10 \%$ & $15 \%$ \\
\hline Wood & $4 \%$ & $3 \%$ \\
\hline Kerosene & $4 \%$ & $3 \%$ \\
\hline Other & $<1 \%$ & $<1 \%$ \\
\hline Does not use heat & $1 \%$ & $<1 \%$ \\
\hline \hline TOTAL & $100 \%$ & $100 \%$ \\
\hline
\end{tabular}

\footnotetext{
${ }^{7}$ Respondents living in multifamily units were not included in the base for this table.

${ }^{8}$ Respondents living in mobile homes were not included in the base for this table.
} 
Table 3.20 shows that almost half of WAP clients report that they used a supplemental source of heat. In general, clients use supplemental heat to reduce costs (e.g., wood stoves) or to improve the distribution of heat to all parts of the home. Since the comparison households were less likely to use a secondary source of heat than the treatment households, it is possible that WAP services allowed some homes to eliminate those supplemental heating sources.

Table 3.20. WAP Clients by Whether Household Uses Secondary Source of Heat

\begin{tabular}{|l|c|c||}
\hline \multicolumn{2}{|l|}{ In the past 12 months, did you use any other types of heating equipment? } \\
\hline \hline & Treatment & Comparison \\
\hline \hline Number of Respondents & 657 & 796 \\
\hline \hline Yes & $46 \%$ & $40 \%$ \\
\hline No & $53 \%$ & $60 \%$ \\
\hline Does not use heat & $1 \%$ & $<1 \%$ \\
\hline \hline TOTAL & $100 \%$ & $100 \%$ \\
\hline
\end{tabular}

Table 3.21 shows that about 85 percent of WAP clients had air conditioning of some type. About half of those households have a central cooling system, while the other half had individual air conditioning units without ducts. Comparison households were similar to treatment households.

Table 3.21. WAP Clients by Type of Air Conditioning Equipment

\begin{tabular}{|c|c|c|}
\hline \multicolumn{3}{|c|}{ Does your home have ducts? } \\
\hline & Treatment & Comparison \\
\hline Number of Respondents & 665 & 802 \\
\hline Yes, Have Central Ducts & $41 \%$ & $42 \%$ \\
\hline Yes, No Central Ducts & $40 \%$ & $41 \%$ \\
\hline Yes, Don't Know Type & $4 \%$ & $4 \%$ \\
\hline No AC Equipment & $16 \%$ & $14 \%$ \\
\hline TOTAL & $100 \%$ & $100 \%$ \\
\hline
\end{tabular}

Table 3.22 shows that most WAP client households have basic appliances that are used in a home. About 90 percent have clothes washers and clothes dryers. Almost all households have a microwave oven.

Comparison households are very similar to treatment households.

Table 3.22. Percent of WAP Clients with Other Appliances in the Household

\begin{tabular}{|c|c|c|}
\hline \multicolumn{3}{|c|}{$\begin{array}{l}\text { Does your household use a microwave oven? Is a clothes washing } \\
\text { machine used in your home? Do you use a clothes dryer in your } \\
\text { home? }\end{array}$} \\
\hline & Treatment & Comparison \\
\hline Number of Respondents & 665 & 803 \\
\hline Microwave & $96 \%$ & $97 \%$ \\
\hline Clothes Washer & $93 \%$ & $95 \%$ \\
\hline Clothes Dryer & $88 \%$ & $89 \%$ \\
\hline
\end{tabular}


The housing unit statistics show that WAP subgrantees are presented with a diverse array of housing unit types, building configurations, heating fuels, and use of supplemental heat. As a result of this diversity, crews must be trained to look at each home as an individual system to ensure that the proper procedures are used to maximize efficiency while maintaining safety. 



\section{HOME HEATING}

This section of the report provides findings from the Baseline Survey on WAP client home heating. It examines three different dimensions of the population of clients served by the program.

- Heating Equipment - The first part of this section presents information on the types of heating equipment used by WAP clients and discusses the special challenges presented by some types of equipment.

- Household Heating Behaviors - The second part of this section presents information on how WAP clients report that they maintain and use their heating systems.

- Heating System Performance - The final part of this section presents client reported information on the performance of the heating system. .

The statistics presented in this section of the report demonstrate that the treatment group households have significant heating system needs that can be addressed by WAP including: use of inadequate heating systems as main equipment, use of potentially dangerous supplemental heating equipment, having broken heating equipment, and having housing units that clients perceive are drafty, cold, and unhealthy or unsafe. Analysis of the comparison group households shows that they had a lower rate of heating system problems than treatment group households, some of which may have been addressed by their program participation.

\subsection{EQUIPMENT}

Table 4.1 shows that the most common type of main heating equipment reported in the Baseline Occupant Survey is a central forced air furnace; that heating equipment type is used by 70 percent of WAP clients. Some clients use common heating systems such as steam/hot water systems, heat pumps, and built-in electric units. However, about 10 percent of clients report using portable heaters, heating stoves, fireplaces, and cooking stoves. Each of these systems presents certain risks to clients who WAP service delivery agencies need to carefully review and address. Comparison households used the same types of heating equipment as treatment households. 
Table 4.1. WAP Clients by Type of Main Heating Equipment

\begin{tabular}{|c|c|c|}
\hline & Treatment & Comparison \\
\hline Number of Respondents & 657 & 797 \\
\hline Central Furnace & $71 \%$ & $72 \%$ \\
\hline Steam/Hot Water System & $7 \%$ & $8 \%$ \\
\hline Built-in Floor/Wall/Room Units & $5 \%$ & $5 \%$ \\
\hline Heating Stove & $4 \%$ & $2 \%$ \\
\hline Portable Heaters & $2 \%$ & $2 \%$ \\
\hline Heat Pump & $3 \%$ & $4 \%$ \\
\hline Built-in Electric Units & $4 \%$ & $6 \%$ \\
\hline Fireplace & $1 \%$ & $1 \%$ \\
\hline Cooking Stove & $<1 \%$ & $<1 \%$ \\
\hline Other & $1 \%$ & $1 \%$ \\
\hline No Heating Used & $1 \%$ & $<1 \%$ \\
\hline TOTAL & $100 \%$ & $100 \%$ \\
\hline
\end{tabular}

Table 4.2 shows that almost one-half of clients report using some type of supplemental heating equipment, with about one-third reporting the use of portable heaters. Electric portable heaters can present safety risks to clients in terms of fires and burns, while other types of unvented portable heaters can introduce dangerous gases into the indoor environment. The comparison households were less likely to report that they used portable heaters.

Table 4.2. WAP Clients by Type of Supplemental Heating Equipment

\begin{tabular}{||l||c||c||}
\hline \hline \multicolumn{1}{|l||}{ What other types of heating equipment did you use in the past 12 months? } \\
\hline \hline Number of Respondents & Treatment & Comparison \\
\hline \hline Portable Heaters & 665 & 800 \\
\hline Heating Stove & $33 \%$ & $27 \%$ \\
\hline Fireplace & $5 \%$ & $4 \%$ \\
\hline Cooking Stove & $3 \%$ & $6 \%$ \\
\hline Other & $3 \%$ & $1 \%$ \\
\hline No Supplemental Heating Used & $54 \%$ & $5 \%$ \\
\hline
\end{tabular}

\subsection{HEATING SYSTEM PRACTICES}

The most direct way that households can affect the amount of energy used for heating their home is by setting their thermostats to a reasonable level and practicing setback. Table 4.3 shows that the average treatment group households sets the thermostat at about 70 degrees during the day when someone is home, and that the temperature is, on average, lower during the day when no one is home and at night. 
Table 4.4 shows that about 27 percent of households practice setback both when no one is home and at night. About 48 percent of households report that they kept the temperature about the same at all times. The comparison group households were more likely to practice setback both when no one is home and at night.

Table 4.3. WAP Clients by Median Household

Temperature $\left({ }^{\circ} \mathbf{F}\right)$ at Different Times of Day During the Winter

\begin{tabular}{||l|c|c||c|c||}
\hline \multicolumn{2}{|c|}{ At what temperature $\left({ }^{\circ} \mathrm{F}\right)$ is the thermostat set in your home during the Winter... } \\
\cline { 2 - 6 } & \multicolumn{2}{|c|}{ Treatment } & \multicolumn{2}{c|}{ Comparison } \\
\hline \hline when someone is home during the day? & 5 & ${ }^{\circ} \mathrm{F}$ & $\#$ & ${ }^{\circ} \mathrm{F}$ \\
\hline when no one is home during the day? & 556 & $69.6^{\circ}$ & 715 & $70.0^{\circ}$ \\
\hline at night? & 569 & $68.2^{\circ}$ & 688 & $67.3^{\circ}$ \\
\hline \hline
\end{tabular}

Table 4.4. WAP Clients by How Household Practices Setback in the Winter

\begin{tabular}{|l|c||c||}
\hline $\begin{array}{l}\text { Does your home have a thermostat that controls the heating? Is your thermostat automatically adjusted } \\
\text { to a lower temperature during the day when no one is home? Is your thermostat automatically adjusted } \\
\text { to a lower temperature at night? }\end{array}$ & Treatment & Comparison \\
\hline \hline & 651 & 774 \\
\hline \hline Number of Respondents & $16 \%$ & $12 \%$ \\
\hline \hline Yes / Daytime & $9 \%$ & $11 \%$ \\
\hline Yes / Night & $27 \%$ & $32 \%$ \\
\hline Yes / Both & $36 \%$ & $35 \%$ \\
\hline No / Does not setback thermostat & $12 \%$ & $10 \%$ \\
\hline No / Does not have heating thermostat & $100 \%$ & $100 \%$ \\
\hline \hline TOTAL & & \\
\hline
\end{tabular}

Table 4.5 shows that a little over one-half of those households with a programmable thermostat automatically setback the temperature. The comparison group households were more likely to have programmable thermostats, but were not more likely to have them change the temperature at different times of the day and at night. However, because a large percentage of WAP client households have an elderly person or a young child at home, they would have less time during the week when the thermostat is setback. Table 4.6 shows that over 80 percent of WAP clients reported that there is someone home "most or all of the day" on a typical weekday.

Table 4.5. WAP Clients by Whether Household Programs Setback in the Winter

\begin{tabular}{|l||c|c|}
\hline \multicolumn{2}{|l|}{ Is your thermostat programmed to change the temperature at different times of the day? } \\
\hline \hline & Treatment & Comparison \\
\hline \hline Number of Respondents & 153 & 271 \\
\hline Yes & $55 \%$ & $52 \%$ \\
\hline \hline TOTAL & $45 \%$ & $48 \%$ \\
\hline
\end{tabular}


Table 4.6. WAP Clients by Whether Someone Is Home Most or All Day During the Week

\begin{tabular}{||l|c|c||}
\hline \hline \multicolumn{1}{||l|}{ On a typical week day is there someone at home most or all of the day? } \\
\hline \hline Number of Respondents & Treatment & Comparison \\
\hline \hline Yes & 659 & 801 \\
\hline No & $83 \%$ & $87 \%$ \\
\hline \hline TOTAL & $17 \%$ & $13 \%$ \\
\hline
\end{tabular}

It is important to have regular heating system maintenance service. The survey showed that 72 percent of treatment households have a furnace, and that about 37 percent of them reported that they had service in the last three years (about one-half of those with furnaces) In this case, the comparison group is significantly different from the treatment group. About 73 percent of comparison group households said that they had a furnace, and about 52 percent of them reported that they had furnace maintenance service in the last three years (almost three-fourths of those with a furnace). That substantial difference is likely due to the WAP services that they had received.

Table 4.7. WAP Clients by When Household Last Received Furnace Maintenance

\begin{tabular}{|c|c|c|}
\hline & Treatment & Comparison \\
\hline Number of Respondents & 658 & 797 \\
\hline Less than 1 year & $21 \%$ & $24 \%$ \\
\hline 1 year to less than 3 years & $16 \%$ & $28 \%$ \\
\hline $3+$ years & $7 \%$ & $3 \%$ \\
\hline Never & $9 \%$ & $9 \%$ \\
\hline Don't Know & $19 \%$ & $9 \%$ \\
\hline Not Applicable - Does not have furnace & $28 \%$ & $27 \%$ \\
\hline TOTAL & $100 \%$ & $100 \%$ \\
\hline
\end{tabular}

Table 4.8 shows that 60 percent of WAP clients who have a central warm air furnace reported that they change their furnace filter at least every three months, and that about 95 percent report changing it at least once a year. The comparison households are a little more likely to change their furnace filter at least every three months ( 65 percent for the comparison group and 60 percent for the treatment group). 
Table 4.8. WAP Clients by How Often Household Changes the Air Filter

\begin{tabular}{|l||c||c||}
\hline \multicolumn{1}{|l||}{$\begin{array}{l}\text { Approximately how often does someone in your household change or clean the air filter in your heating } \\
\text { system? }\end{array}$} & Treatment & Comparison \\
\hline \hline Number of respondents who have an air filter & 434 & 594 \\
\hline \hline Monthly & $26 \%$ & $30 \%$ \\
\hline Every 3 months & $34 \%$ & $35 \%$ \\
\hline Every 6 months & $14 \%$ & $16 \%$ \\
\hline Once a year & $21 \%$ & $17 \%$ \\
\hline Once every 2 years & $2 \%$ & $<1 \%$ \\
\hline Don't change (or clean) it & $2 \%$ & $<1 \%$ \\
\hline Air filter is changed by service company & $1 \%$ & $1 \%$ \\
\hline \hline TOTAL & $100 \%$ & $100 \%$ \\
\hline
\end{tabular}

Tables 4.9 through 4.11 furnish information on a number of different heating practices that each have certain risks. Some findings from those tables include:

- Table 4.9 shows that 15 percent of treatment group households used a heating stove or fireplace for main or supplemental heat; many of those burned poor quality wood, waste wood, or other waste materials. Comparison group households reported lower rates for both types of heating practices.

- Table 4.10 shows that four percent of treatment group households reported using cooking stoves to supply heat. The rate was less than half that for comparison group households.

- Table 4.11 shows that about 35 percent of treatment group households reported using a portable heater. Fewer comparison group households ( 28 percent) reported using them.

In all cases, households in weatherized homes had a lower rate of risk than those that had not yet been weatherized.

Table 4.9. WAP Clients by Whether Household Uses a Heating Stove or Fireplace for Heat and What Type of Wood the Household Uses

What other types of heating equipment did you use in the last 12 months? In the past 12 months how often did you have to use poor quality wood, waste wood, or other waste materials?

\begin{tabular}{||l|c|c||}
\hline \hline Number of Respondents & Treatment & Comparison \\
\hline \hline Yes & 657 & 795 \\
\hline Burned poor quality wood & $15 \%$ & $13 \%$ \\
\hline Burned waste wood & $4.6 \%$ & $1.9 \%$ \\
\hline Burned other waste materials & $1.8 \%$ & $0.8 \%$ \\
\hline No & $3.0 \%$ & $0.8 \%$ \\
\hline
\end{tabular}


Table 4.10. WAP Clients by Whether Household Uses a Cooking Stove for Heat

\begin{tabular}{|l||c|c||}
\hline \multicolumn{2}{|c|}{ In the past 12 months how often have you used your oven to heat your home? } \\
\hline \hline Number of Respondents & Treatment & Comparison \\
\hline \hline Yes & 657 & 795 \\
\hline No & $3.7 \%$ & $1.5 \%$ \\
\hline \hline TOTAL & $96.4 \%$ & $98.5 \%$ \\
\hline \hline
\end{tabular}

Table 4.11. WAP Clients by Whether Household Uses a Portable Heater

\begin{tabular}{|l||c|c||}
\hline \multicolumn{2}{|c|}{ What other types of heating equipment did you use in the past 12 months? } \\
\hline \hline & Treatment & Comparison \\
\hline \hline Number of Respondents & 657 & 795 \\
\hline \hline Yes & $36 \%$ & $29 \%$ \\
\hline No & $64 \%$ & $71 \%$ \\
\hline \hline TOTAL & $100 \%$ & $100 \%$ \\
\hline
\end{tabular}

\subsection{HEATING SYSTEM PERFORMANCE}

The Baseline Occupant Survey asked a number of questions that help us to understand the performance of the household's heating system for delivering heat to the home. Table 4.12 shows that about 15 percent of treatment group households were unable to use their main heating equipment in the last year because it was broken. The rate for comparison group households was about one-half as much (eight percent).

Table 4.12. WAP Clients by Whether Main Heating Equipment

Broken in the Past 12 Months When Household Needed it

In the past 12 months, was your household unable to use your main heating equipment because it was broken?

\begin{tabular}{|l|c||c|}
\hline \hline & Treatment & Comparison \\
\hline \hline Number of Respondents & 663 & 802 \\
\hline \hline Yes & $15 \%$ & $8 \%$ \\
\hline No & $85 \%$ & $92 \%$ \\
\hline \hline Total & $100 \%$ & $100 \%$ \\
\hline
\end{tabular}

Table 4.13 shows that 29 percent of treatment group households reported that their home was too drafty most or all of the time. Only 29 percent reported that their home was never drafty. The majority of comparison group households (63 percent) reported that their home was never drafty, and only nine percent reported that their home was drafty most or all of the time. 
Table 4.13. WAP Clients by How Often Home Is Too Drafty

\begin{tabular}{|l||c||c|}
\hline \hline $\begin{array}{l}\text { During the past } 12 \text { months, how often have you or other members of your } \\
\text { household found your home too drafty? }\end{array}$ & Treatment & Comparison \\
\hline \hline & 657 & 799 \\
\hline \hline Number of Respondents & $13 \%$ & $4 \%$ \\
\hline \hline All the time & $16 \%$ & $5 \%$ \\
\hline Most of the time & $42 \%$ & $29 \%$ \\
\hline Some of the time & $29 \%$ & $63 \%$ \\
\hline Never & $100 \%$ & $100 \%$ \\
\hline \hline TOTAL & & \\
\hline
\end{tabular}

Table 4.14 shows how the treatment group households reported their comfort in the home during the winter. About 39 percent of households reported that their home was cold or very cold. However, those same clients reported an average temperature in the home of 69 degrees. About 58 percent reported that their home was comfortable; those households reported an average temperature of 70 degrees. In general, the data for comparison group households shows that a much higher percentage reported that their home was a comfortable temperature (78 percent) at the same 70 degrees.

Table 4.14. WAP Clients by Comfort of Home and Temperature of Home in Winter

\begin{tabular}{|c|c|c|c|c|}
\hline \multicolumn{5}{|c|}{$\begin{array}{l}\text { During the winter at what temperature is your thermostat set when someone is inside your } \\
\text { home during the day? Is the indoor temperature of your home during the winter... }\end{array}$} \\
\hline & \multicolumn{2}{|c|}{ Treatment } & \multicolumn{2}{|c|}{ Comparison } \\
\hline Number of Respondents & $\mathrm{N}=661$ & $\begin{array}{l}{ }^{\circ} \mathrm{F} \\
\text { Someone } \\
\text { home } \\
\text { during the } \\
\text { day }\end{array}$ & $\mathrm{N}=799$ & $\begin{array}{c}{ }^{\circ} \mathrm{F} \\
\text { Someone } \\
\text { home } \\
\text { during the } \\
\text { day }\end{array}$ \\
\hline very cold? & $6 \%$ & $69^{\circ}$ & $3 \%$ & $71^{\circ}$ \\
\hline cold? & $33 \%$ & $69^{\circ}$ & $17 \%$ & $69^{\circ}$ \\
\hline comfortable? & $58 \%$ & $70^{\circ}$ & $78 \%$ & $70^{\circ}$ \\
\hline hot? & $2 \%$ & $71^{\circ}$ & $1 \%$ & $75^{\circ}$ \\
\hline very hot? & $<1 \%$ & $75^{\circ}$ & $<1 \%$ & $70^{\circ}$ \\
\hline other? & $<1 \%$ & $68^{\circ}$ & $1 \%$ & $72^{\circ}$ \\
\hline TOTAL & $100 \%$ & $70^{\circ}$ & $100 \%$ & $70^{\circ}$ \\
\hline
\end{tabular}

Table 4.15 compares the client percent of comfort in homes with the client's perception of how drafty their home was during the winter. About 54 percent of households who perceived that their home was very cold reported that their home was drafty most or all of the time. Only 16 percent of clients who said that their home was a comfortable temperature in the winter reported that their home was drafty most or all of the time. The comparison group of households shows a similar pattern of response. 
Table 4.15. WAP Clients by Household

Comfort of Home and Home Draftiness in the Winter

\begin{tabular}{|c|c|c|c|c|}
\hline \multicolumn{5}{|c|}{$\begin{array}{l}\text { During the past } 12 \text { months, how often have you or other members of } \\
\text { your household found your home too drafty? Is the indoor temperature } \\
\text { of your home during the winter... }\end{array}$} \\
\hline & \multicolumn{2}{|c|}{ Treatment } & \multicolumn{2}{|c|}{ Comparison } \\
\hline $\begin{array}{l}\text { Number of } \\
\text { Respondents }\end{array}$ & $\mathrm{N}=661$ & $\begin{array}{l}\% \text { drafty } \\
\text { all/most } \\
\text { of the } \\
\text { time }\end{array}$ & $\mathrm{N}=799$ & $\begin{array}{l}\% \text { drafty } \\
\text { all/most } \\
\text { of the } \\
\text { time }\end{array}$ \\
\hline very cold? & $6 \%$ & $54 \%$ & $3 \%$ & $46 \%$ \\
\hline cold? & $33 \%$ & $47 \%$ & $17 \%$ & $20 \%$ \\
\hline comfortable? & $58 \%$ & $16 \%$ & $78 \%$ & $5 \%$ \\
\hline hot? & $2 \%$ & $25 \%$ & $1 \%$ & $0 \%$ \\
\hline very hot? & $<1 \%$ & $0 \%$ & $<1 \%$ & $0 \%$ \\
\hline other? & $<1 \%$ & $67 \%$ & $1 \%$ & $0 \%$ \\
\hline TOTAL & $100 \%$ & $29 \%$ & $100 \%$ & $9 \%$ \\
\hline
\end{tabular}

Table 4.16 shows how often treatment group clients reported that they had to keep their home at an unsafe or unhealthy temperature. About 18 percent of clients reported that they had to keep their home at an unsafe temperature at least one month, and 10 percent reported that they had an unhealthy or unsafe temperature in at least three months. Table 4.17 shows that 3.2 percent of treatment group households reported that someone in the home needed medical attention because the home was too cold. Nine percent of comparison group households reported keeping their home at an unsafe temperature and only five percent reported that their home was an unsafe temperature in at least three months; 2.1 percent of comparison group households reported that someone in the home needed medical attention because the home was too cold.

Table 4.16. WAP Clients by How Often the Household Kept the Home at an Unsafe or Unhealthy Temperature

\begin{tabular}{|c|c|c|}
\hline \multicolumn{3}{|c|}{$\begin{array}{l}\text { In the past } 12 \text { months how often did your household keep your home at a } \\
\text { temperature that you felt was unsafe or unhealthy? }\end{array}$} \\
\hline & Treatment & Comparison \\
\hline Number of Respondents & 661 & 796 \\
\hline Almost every month & $3 \%$ & $2 \%$ \\
\hline Some months & $7 \%$ & $3 \%$ \\
\hline 1 or 2 months & $8 \%$ & $4 \%$ \\
\hline Never & $82 \%$ & $91 \%$ \\
\hline TOTAL & $100 \%$ & $100 \%$ \\
\hline
\end{tabular}


Table 4.17. WAP Clients by Whether Household Member Received Medical Attention Because the Home Was Too Cold

\begin{tabular}{|l||c||c|}
\hline $\begin{array}{l}|l| \mid \\
\text { In the past year, did anyone in your household need medical attention } \\
\text { because the home was too cold? }\end{array}$ & Treatment & Comparison \\
\hline \hline & 665 & 803 \\
\hline \hline Number of Respondents & $3.2 \%$ & $2.1 \%$ \\
\hline Yes & $96.8 \%$ & $97.9 \%$ \\
\hline \hline No & $100 \%$ & $100 \%$ \\
\hline
\end{tabular}

Table 4.18 shows how indoor temperature affects students, as well as the potential impact that weatherization can have on students. In the treatment group, about 28 percent of households reported that their child at some time found it hard to study at home because the home was too hot or too cold, and that eight percent of households reported that this happened frequently. Only 13 percent of comparison group households reported that this happened, and only four percent reported that it happened frequently.

Table 4.18. WAP Clients by Difficulty Faced by Child Studying Because of Excessive Heat/Cold

\begin{tabular}{|l|c|c||}
\hline \multicolumn{1}{|l|}{$\begin{array}{l}\text { In the past } 12 \text { months, how frequently did any school aged child in the home find } \\
\text { it hard to study because of excessive heat or cold? }\end{array}$} & Treatment & Comparison \\
\hline \hline & 196 & 196 \\
\hline \hline $\begin{array}{l}\text { Number of respondents with school age } \\
\text { children in the home }\end{array}$ & $2 \%$ & $2 \%$ \\
\hline \hline Very frequently & $6 \%$ & $2 \%$ \\
\hline Frequently & $5 \%$ & $1 \%$ \\
\hline Not frequently or infrequently & $10 \%$ & $4 \%$ \\
\hline Infrequently & $5 \%$ & $6 \%$ \\
\hline Very infrequently & $71 \%$ & $86 \%$ \\
\hline Never & $1 \%$ & $1 \%$ \\
\hline Does not study at home & $100 \%$ & $100 \%$ \\
\hline \hline TOTAL & & \\
\hline
\end{tabular}

In general, the statistics reported in this section demonstrate that a significant percentage of treatment group clients perceive that their home does not perform adequately; many report that their home is cold and drafty. There appears to be a very strong relationship between the perception that the home is cold and the perception that the home is drafty. A small, but significant number of households reported that at least one household member required medical attention because their home was too cold.

\subsection{SUMMARY OF HEATING SYSTEM FINDINGS}

It is clear that WAP clients have significant heating system needs that can be addressed by WAP. Through the Occupant Follow-Up Survey, the study will obtain a direct measure of how the status of households changed. However, in the Baseline Survey, the comparison group households reported on their home heating experience for the year following weatherization. Some key differences between treatment group and comparison group households are shown in Table 4.19 and suggest the extent to which WAP may have helped to resolve problems faced by client households. The statistics show that 
participation in WAP is associated with substantial improvements in both heating system practices and heating system performance and outcomes.

Table 4.19. Summary of WAP Household Heating System Findings

\begin{tabular}{|c|c|c|c|}
\hline Indicator & Treatment & Comparison & $\begin{array}{c}\text { Percent } \\
\text { Difference }\end{array}$ \\
\hline Poor Quality Materials Burned & $6.5 \%$ & $2.6 \%$ & $-60 \%$ \\
\hline Use Cooking Stove for Heat & $3.6 \%$ & $1.5 \%$ & $-58 \%$ \\
\hline Use Portable Heater & $36 \%$ & $28 \%$ & $-22 \%$ \\
\hline Heating System Broken & $15 \%$ & $8 \%$ & $-47 \%$ \\
\hline Home Drafty Most or All of the Time & $29 \%$ & $9 \%$ & $-69 \%$ \\
\hline Home Cold or Very Cold & $39 \%$ & $20 \%$ & $-49 \%$ \\
\hline Home Kept at Unsafe Temperature & $10 \%$ & $5 \%$ & $-50 \%$ \\
\hline Medical Attention Needed & $3.2 \%$ & $2.1 \%$ & $-35 \%$ \\
\hline
\end{tabular}




\section{HOME COOLING}

This section of the report provides findings from the Baseline Survey on WAP client home cooling. It examines three different dimensions of the population of clients served by the program.

- Cooling Equipment - The first part of this section presents information on the types of cooling equipment used by WAP clients.

- Household Cooling Behaviors - The second part of this section presents information on how WAP clients report that they maintain and use their cooling systems.

- Cooling System Performance - The final part of this section presents client reported information on the performance of the cooling system.

The statistics presented in this section demonstrate that the treatment group households have cooling system needs that can be addressed by WAP including having broken cooling equipment and having housing units that are too hot in the summer. Analysis of the comparison group households shows that they had a lower rate of cooling system problems than treatment group households which may have been a result of program participation

\subsection{COOLING EQUIPMENT}

Table 5.1 shows that 76 percent of treatment group clients report having some form of air conditioning equipment that they use; one-third have a central system, over one-third have window and/or wall units, and about five percent use evaporative coolers. The use of cooling equipment is slightly higher ( 81 percent) for comparison group households.

Table 5.1. WAP Clients by Main Cooling Equipment

\begin{tabular}{|l||c||c||}
\hline \multicolumn{1}{|l|}{ Is any air conditioning equipment used in your home? } \\
\hline \hline & Treatment & Comparison \\
\hline \hline Number of Respondents & 655 & 798 \\
\hline \hline Central air conditioning & $33 \%$ & $37 \%$ \\
\hline Wall/Window units & $38 \%$ & $37 \%$ \\
\hline Swamp/Evaporative cooling & $5 \%$ & $7 \%$ \\
\hline Have equipment, don't use & $8 \%$ & $6 \%$ \\
\hline Don't have equipment & $16 \%$ & $13 \%$ \\
\hline \hline Total & $100 \%$ & $100 \%$ \\
\hline \hline
\end{tabular}

Table 5.2 shows how treatment group households used their air conditioning equipment during the summer months. Almost one-half of clients (49 percent) had their air conditioning systems on consistently during the summer. About one-fourth of clients (27 percent) used their system only a few days. A slightly higher proportion of comparison group clients used air conditioning consistently (51 percent) and occasionally (29 percent). 
Table 5.2. WAP Clients by How Household Used AC Last Summer

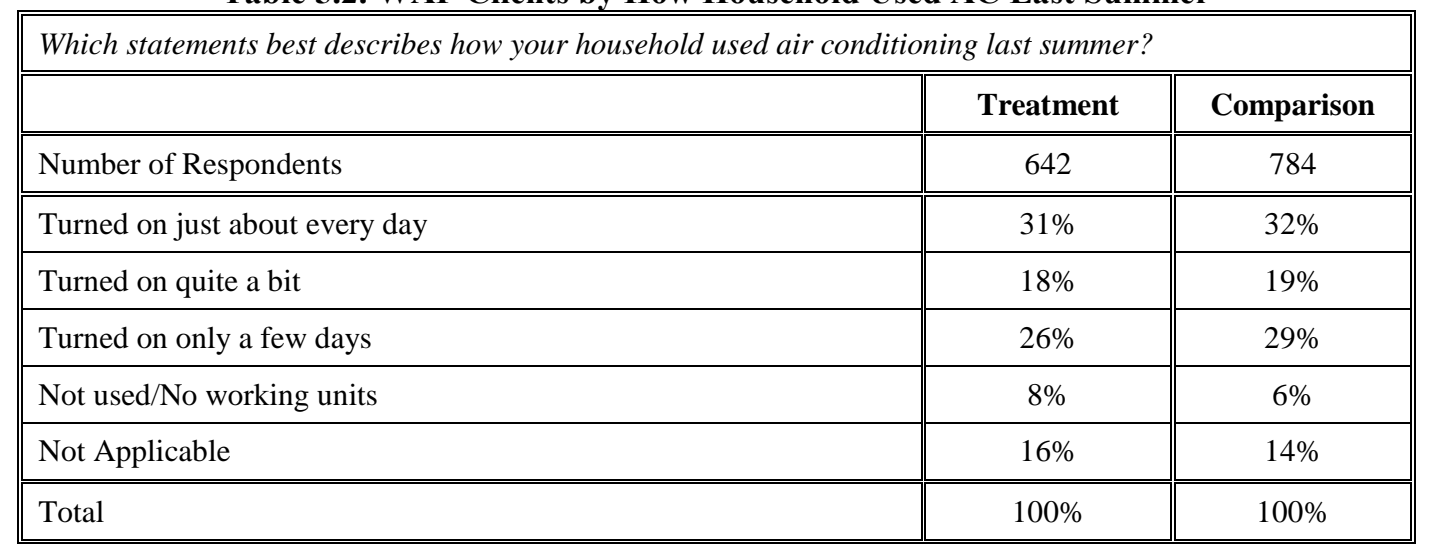

\subsection{COOLING SYSTEM PRACTICES}

The most direct way that households can affect the energy used for cooling their home is by setting their thermostats to a reasonable level and practicing setback. Table 5.3 shows that the average treatment group household sets the thermostat at about 74 degrees during the day when someone is home, and that the temperature is higher during the day when no one is home, but is about the same at night. Table 5.4 shows that about 18 percent of households practice setback at some time and that comparison group households report a similar rate. This may indicate that there is a missed opportunity to educate clients about thermostat setback when no one is at home during the day.

Table 5.3. WAP Clients by Median Household Temperature $\left({ }^{\circ} \mathrm{F}\right)$ at Different Times of Day in the Summer

\begin{tabular}{||l||c||c|c|c||}
\hline \hline \multicolumn{1}{|c|}{ At what temperature $\left({ }^{\circ} \mathrm{F}\right)$ is the thermostat set in your home during the summer... } \\
\cline { 2 - 6 } & \multicolumn{1}{|c||}{ Treatment } & \multicolumn{2}{|c||}{ Comparison } \\
\cline { 2 - 6 } & & ${ }^{\circ} \mathrm{F}$ & $\#$ & ${ }^{\circ} \mathrm{F}$ \\
\hline \hline When someone is home during the day? & 232 & $73.8^{\circ}$ & 301 & $73.8^{\circ}$ \\
\hline When no one is home during the day? & 207 & $75.0^{\circ}$ & 260 & $74.6^{\circ}$ \\
\hline At night? & 215 & $74.0^{\circ}$ & 272 & $74.0^{\circ}$ \\
\hline
\end{tabular}


Table 5.4. WAP Clients by Whether Household Practices Setback in the Summer

\begin{tabular}{|c|c|c|}
\hline \multicolumn{3}{|l|}{ Thermostat setback questions } \\
\hline & Treatment & Comparison \\
\hline Number of Respondents & 657 & 787 \\
\hline Yes / Daytime & $9 \%$ & $10 \%$ \\
\hline Yes / Night & $3 \%$ & $3 \%$ \\
\hline Yes / Both & $6 \%$ & $6 \%$ \\
\hline No / Does not setback thermostat & $19 \%$ & $20 \%$ \\
\hline No / Does not have cooling thermostat & $64 \%$ & $61 \%$ \\
\hline TOTAL & $100 \%$ & $100 \%$ \\
\hline
\end{tabular}

It is easier for households to practice setback when they have a programmable thermostat. Table 5.5 shows that about 12 percent of treatment group households had a programmable thermostat before weatherization. Table 5.6 shows that in about one-half of those households the programmable thermostat automatically setback the temperature. The comparison group households were more likely to have programmable thermostats, and for about one-half the thermostat automatically setback the temperature.

Table 5.5. WAP Clients by Presence of Thermostat for Cooling

\begin{tabular}{||l||c||c||}
\hline \multicolumn{2}{|l||}{ Does your thermostat control central cooling? Is the thermostat programmable? } \\
\hline \hline & Treatment & Comparison \\
\hline \hline Number of Respondents & 656 & 792 \\
\hline \hline Programmable Thermostat & $12 \%$ & $17 \%$ \\
\hline Manual Thermostat & $24 \%$ & $22 \%$ \\
\hline Neither & $64 \%$ & $61 \%$ \\
\hline \hline Total & $100 \%$ & $100 \%$ \\
\hline
\end{tabular}

Table 5.6. WAP Clients by Household Programs Setback on Cooling Thermostat

\begin{tabular}{|l|c|c||}
\hline \multicolumn{1}{|l||}{$\begin{array}{l}\text { Is your thermostat programmed to change the temperature at different } \\
\text { times of the day? }\end{array}$} & Treatment & Comparison \\
\hline \hline & 77 & 130 \\
\hline \hline Number of Respondents & $48 \%$ & $52 \%$ \\
\hline \hline Yes & $52 \%$ & $48 \%$ \\
\hline No & $100 \%$ & $100 \%$ \\
\hline \hline TOTAL & & \\
\hline
\end{tabular}

Tables 5.7 through 5.9 furnish information on a number of different cooling practices that can help to improve the performance of the cooling system and reduce the cost of keeping the home at a safe and comfortable temperature. Some findings from those tables include: 
- Table 5.7 shows that about 69 percent of treatment group households used a ceiling fan in the summer. A slightly higher percentage of comparison group households ( 74 percent) reported using ceiling fans.

- Table 5.8 shows that about 37 percent of treatment group households reported that they used cross-ventilation to help keep their home cool in the summer. About the same percentage of comparison group households reported using cross-ventilation.

- Table 5.9 shows that 89 percent of treatment group households reported closing the blinds or drapes in the summer to keep out the heat. A slightly higher percentage of comparison group households (90 percent) reported doing that.

In general, a high percentage of treatment group clients and a similar percentage of comparison group clients reported that they adopted these good cooling practices.

Table 5.7. WAP Clients by Whether Household Uses Ceiling Fans in Summer Thinking about the ceiling fan that you use the most, how often was this fan used last summer? Was it not used at all, used only a few days or nights, used quite a bit, used just about all summer?

\begin{tabular}{|l|c||c||}
\hline \hline Number of Respondents & Treatment & Comparison \\
\hline \hline Used at least a few days or nights & 658 & 802 \\
\hline Not used at all & $69 \%$ & $74 \%$ \\
\hline Not Applicable & $3 \%$ & $2 \%$ \\
\hline \hline TOTAL & $28 \%$ & $24 \%$ \\
\hline
\end{tabular}

Table 5.8. WAP Clients by Whether Household Uses Cross Ventilation

In the past 12 months, has your household used window fans to assist with natural cross ventilation in the warmer months?

\begin{tabular}{||l||c||c||}
\hline \hline Number of Respondents & Treatment & Comparison \\
\hline \hline Yes & 664 & 803 \\
\hline No & $37 \%$ & $36 \%$ \\
\hline \hline TOTAL & $63 \%$ & $64 \%$ \\
\hline
\end{tabular}

Table 5.9. WAP Clients by Whether Household Closes Drapes, Curtains, Shades, Blinds

\begin{tabular}{|c|c|c|}
\hline \multicolumn{3}{|c|}{$\begin{array}{l}\text { Do you close the drapes, curtains, shades, and/or blinds during the day } \\
\text { to block out the sun during the summer? }\end{array}$} \\
\hline & Treatment & Comparison \\
\hline Number of Respondents & 663 & 801 \\
\hline Yes & $89 \%$ & $90 \%$ \\
\hline No & $11 \%$ & $10 \%$ \\
\hline TOTAL & $100 \%$ & $100 \%$ \\
\hline
\end{tabular}


Table 5.10 shows that only about one-half of treatment group clients reported that they had large shade trees that could help to keep their home cool during the summer. A similar percentage of comparison group households reported having large shade trees.

Table 5.10. WAP Clients by Whether Household Has

Large Trees That Shade Home from the Summer Sun

\begin{tabular}{|l|c|c||}
\hline \multicolumn{2}{|l|}{ Do any large trees shade your home from the afternoon summer sun? } \\
\hline \hline & Treatment & Comparison \\
\hline \hline Number of Respondents & 662 & 801 \\
\hline \hline Yes & $54 \%$ & $57 \%$ \\
\hline No & $46 \%$ & $43 \%$ \\
\hline \hline TOTAL & $100 \%$ & $100 \%$ \\
\hline
\end{tabular}

41 percent of treatment group clients reported that they had their windows open frequently or all of the time during the summer months. In general, keeping the windows open is a reasonable practice. However, for households with an individual with asthma or other respiratory problems, continuous exposure to outdoor air can exacerbate symptoms. The comparison group clients reported opening windows at about the same rate as treatment group households.

Table 5.11. WAP Clients by How Often Household Opens Windows in Summer

\begin{tabular}{|l||c|c|}
\hline \multicolumn{1}{|l|}{ How often are your windows open in the summer? } \\
\hline \hline & Treatment & Comparison \\
\hline \hline Number of Respondents & 665 & 800 \\
\hline \hline Never & $15 \%$ & $14 \%$ \\
\hline Rarely & $18 \%$ & $16 \%$ \\
\hline Sometimes & $25 \%$ & $24 \%$ \\
\hline Frequently & $24 \%$ & $27 \%$ \\
\hline All the time & $17 \%$ & $19 \%$ \\
\hline \hline TOTAL & $100 \%$ & $100 \%$ \\
\hline \hline
\end{tabular}

The responses in Tables 5.7 through 5.11 show that, in most cases, WAP clients are already making use of reasonable passive cooling practices. However, it may be possible that there are additional opportunities for clients to use cross-ventilation as an effective cooling strategy.

\subsection{COOLING SYSTEM PERFORMANCE}

The Baseline Occupant Survey asked a number of questions that help us to understand the performance of the household's cooling system for delivering cool air to the home. Table 5.12 shows that about 15 percent of treatment group households were unable to use their main cooling equipment in the last year because it was broken. The rate for comparison group households was about one-half as much (eight percent). 
Table 5.12. WAP Clients by Whether Main Cooling Equipment Broke in Past 12 Months When Household Wanted to Use It

In the past 12 months, was your household unable to use any of the following equipment because it was broken?

\begin{tabular}{|c|c|c|}
\hline & Treatment & Comparison \\
\hline Number of Respondents & 663 & 801 \\
\hline \multicolumn{3}{|l|}{ Have Equipment } \\
\hline Central AC Broken & $10 \%$ & $5 \%$ \\
\hline Room AC Broken & $5 \%$ & $3 \%$ \\
\hline Neither Broken & $70 \%$ & $79 \%$ \\
\hline \multicolumn{3}{|l|}{ Don't Have Equipment } \\
\hline Central AC Broken & $<1 \%$ & $<1 \%$ \\
\hline Room AC Broken & $<1 \%$ & $<1 \%$ \\
\hline No equipment & $15 \%$ & $13 \%$ \\
\hline
\end{tabular}

Table 5.13 shows how the treatment group households reported their comfort in the home during the summer. About 41 percent of households reported that their home was hot or very hot. Those clients reported an average temperature in the home of about 74 degrees. However, about 55 percent reported that their home was comfortable; those households also reported an average temperature of 74 degrees. In general, the data for comparison group households shows that a much higher percentage reported that their home was a comfortable temperature (70 percent) at the same 74 degrees. It is possible that this presents an education opportunity. Now that their home performs better (i.e., is less drafty and less humid), the client may be able to raise the thermostat temperature to save energy, but remain just as comfortable.

Table 5.13. WAP Clients by Comfort of Home and Temperature of Home in the Summer

\begin{tabular}{|c|c|c|c|c|}
\hline & \multicolumn{2}{|c|}{ Treatment } & \multicolumn{2}{|c|}{ Comparison } \\
\hline $\begin{array}{l}\text { Number of } \\
\text { Respondents }\end{array}$ & $\mathrm{N}=665$ & $\begin{array}{c}{ }^{\circ} \mathrm{F} \text { Home during the } \\
\text { day }(\mathrm{n}=232)\end{array}$ & $\mathrm{N}=803$ & $\begin{array}{c}{ }^{\circ} \mathrm{F} \text { Home during the } \\
\text { day }(\mathrm{n}=301)\end{array}$ \\
\hline very cold? & $<1 \%$ & $60^{\circ}$ & $<1 \%$ & $72^{\circ}$ \\
\hline cold? & $3 \%$ & $74^{\circ}$ & $3 \%$ & $72^{\circ}$ \\
\hline comfortable? & $55 \%$ & $74^{\circ}$ & $70 \%$ & $74^{\circ}$ \\
\hline hot? & $29 \%$ & $73^{\circ}$ & $22 \%$ & $72^{\circ}$ \\
\hline very hot? & $12 \%$ & $75^{\circ}$ & $5 \%$ & $73^{\circ}$ \\
\hline other? & $1 \%$ & $75^{\circ}$ & $1 \%$ & $73^{\circ}$ \\
\hline TOTAL & $100 \%$ & $74^{\circ}$ & $100 \%$ & $74^{\circ}$ \\
\hline
\end{tabular}

Table 5.14 compares the client perception of comfort in homes with the client's perception of the draftiness of their home. About 46 percent of households who perceived that their home was very hot reported that their home was drafty most or all of the time. Only 19 percent of clients who said that there 
home was a comfortable temperature in the summer reported that their home was drafty most or all of the time. The comparison group of households shows a similar pattern of response.

Table 5.14. WAP Clients by Comfort of Home and Draftiness of Home in the Summer

\begin{tabular}{|c|c|c|c|c|}
\hline \multicolumn{5}{|c|}{$\begin{array}{l}\text { During the past } 12 \text { months, how often have you or other members of your household found your } \\
\text { home too drafty? Is the indoor temperature of your home typically... }\end{array}$} \\
\hline & \multicolumn{2}{|c|}{ Treatment } & \multicolumn{2}{|c|}{ Comparison } \\
\hline $\begin{array}{l}\text { Number of } \\
\text { Respondents }\end{array}$ & $\mathrm{N}=665$ & $\begin{array}{c}\% \text { drafty } \\
\text { all/most of the } \\
\text { time }\end{array}$ & $\mathrm{N}=803$ & $\begin{array}{c}\% \text { drafty } \\
\text { all/most of the } \\
\text { time }\end{array}$ \\
\hline very cold? & $<1 \%$ & $50 \%$ & $<1 \%$ & $50 \%$ \\
\hline cold? & $3 \%$ & $32 \%$ & $3 \%$ & $9 \%$ \\
\hline comfortable? & $55 \%$ & $19 \%$ & $70 \%$ & $7 \%$ \\
\hline hot? & $29 \%$ & $42 \%$ & $22 \%$ & $11 \%$ \\
\hline very hot? & $12 \%$ & $46 \%$ & $5 \%$ & $21 \%$ \\
\hline Other & $1 \%$ & $33 \%$ & $1 \%$ & $17 \%$ \\
\hline TOTAL & $100 \%$ & $29 \%$ & $100 \%$ & $9 \%$ \\
\hline
\end{tabular}

Table 5.15 shows how often treatment group clients reported they had to keep their home at an unsafe or unhealthy temperature. About 18 percent of clients reported that they had to keep their home at an unsafe temperature at least one month, and 10 percent reported that they had an unhealthy or unsafe temperature in at least three months. Table 5.16 shows that 2.4 percent of treatment group households reported that someone in the home needed medical attention because the home was too hot. Nine percent of comparison group households reported keeping their home at an unsafe temperature, and only five percent reported that their home was an unsafe temperature in at least three months; 1.1 percent of comparison group households reported someone in the home needed medical attention because the home was too hot.

Table 5.15. WAP Clients by How Often Household Keeps Home at Unsafe or Unhealthy Temperature

\begin{tabular}{|c|c|c|}
\hline \multicolumn{3}{|c|}{$\begin{array}{l}\text { In the past } 12 \text { months how often did your household keep your home at a } \\
\text { temperature that you felt was unsafe or unhealthy? }\end{array}$} \\
\hline & Treatment & Comparison \\
\hline Number of Respondents & 661 & 796 \\
\hline Almost every month & $3 \%$ & $2 \%$ \\
\hline Some months & $7 \%$ & $3 \%$ \\
\hline 1 or 2 months & $8 \%$ & $4 \%$ \\
\hline Never & $82 \%$ & $91 \%$ \\
\hline TOTAL & $100 \%$ & $100 \%$ \\
\hline
\end{tabular}


Table 5.16. WAP Clients by Whether Household Member Received Medical Attention Because Home Was Too Hot

\begin{tabular}{|c|c|c|}
\hline \multicolumn{3}{|c|}{$\begin{array}{l}\text { In the past year, did anyone in your household need medical attention } \\
\text { because the home was too hot? }\end{array}$} \\
\hline & Treatment & Comparison \\
\hline Number of Respondents & 665 & 803 \\
\hline Yes & $2.4 \%$ & $1.1 \%$ \\
\hline No & $97.6 \%$ & $98.9 \%$ \\
\hline Total & $100 \%$ & $100 \%$ \\
\hline
\end{tabular}

In general, the statistics reported in this section demonstrate that a significant percentage of treatment group clients perceive that their home does not perform adequately; many report that their home is hot or very hot in the summer. A small, but significant number of households reported that at least one household member required medical attention because their home was too hot.

It is clear that WAP clients have significant cooling system needs that can be addressed by WAP. Through the Occupant Follow-Up Survey, the study will obtain a direct measure of how the status of households changed. However, in the Baseline Survey, the comparison group households reported on their home cooling experience for the year following weatherization. Some key differences between treatment group and comparison group households are shown in Table 5.17 and suggest the extent to which WAP may have helped to resolve problems faced by client households. The statistics show that participation in WAP was not associated with substantial increases in supplemental cooling strategies, but that participation in the program is associated with improved cooling system performance and outcomes.

Table 5.17. Summary of WAP Household Cooling System Findings

\begin{tabular}{|c|c|c|c|}
\hline Indicator & Treatment & Comparison & $\begin{array}{c}\text { Percent } \\
\text { Difference }\end{array}$ \\
\hline Have cooling system & $74 \%$ & $79 \%$ & $+7 \%$ \\
\hline Use cross ventilation & $37 \%$ & $36 \%$ & $-3 \%$ \\
\hline Close Blinds/Drapes & $89 \%$ & $90 \%$ & $+1 \%$ \\
\hline Cooling System Broken & $15 \%$ & $8 \%$ & $-47 \%$ \\
\hline Home Kept at Unsafe Temperature & $10 \%$ & $5 \%$ & $-50 \%$ \\
\hline Medical Attention Needed & $2.4 \%$ & $1.1 \%$ & $-55 \%$ \\
\hline
\end{tabular}




\section{OTHER ENERGY EFFICIENCY OPPORTUNITIES}

This section of the report provides findings from the Baseline Survey on WAP client energy efficiency behaviors. While weatherization services often focus on reducing usage for home heating and home cooling, the program also has the opportunity to assist the client with other energy efficiency practices. This section includes information on:

- $\quad$ Lighting Practices and Equipment

- Hot Water Practices and Equipment

- Other Energy Efficiency Practices

The analysis in this section generally shows that many treatment group households could improve their energy efficiency practices and thereby reduce energy consumption. Some households already use compact fluorescent lights (CFLs), recycle them properly, purchase Energy Star appliances, and wash and rinse their clothes in cold water.

\subsection{LIGHTING PRACTICES AND EQUIPMENT}

Table 6.1 shows that 35 percent of treatment group households report that they sometimes find lights on, while 38 percent of comparison group households report that they sometimes find lights on. This finding suggests that there is some opportunity for educating clients about the lost energy associated with leaving lights on in rooms that are not occupied.

Table 6.1. WAP Clients by How Often Household Leaves Lights On in Unoccupied Rooms

\begin{tabular}{|c|c|c|}
\hline \multicolumn{3}{|c|}{ How often do you find lights left on in rooms that are not occupied? } \\
\hline & Treatment & Comparison \\
\hline Number of Respondents & 660 & 800 \\
\hline All the time & $3 \%$ & $3 \%$ \\
\hline Most of the time & $5 \%$ & $6 \%$ \\
\hline Sometimes & $27 \%$ & $29 \%$ \\
\hline Almost Never & $33 \%$ & $28 \%$ \\
\hline Never & $33 \%$ & $34 \%$ \\
\hline TOTAL & $100 \%$ & $100 \%$ \\
\hline
\end{tabular}

The majority of treatment group clients (64 percent) reported that they purchase CFLs for their homes. Since CFLs are significantly more expensive than incandescent bulbs, this finding suggests that these households are making investments in saving energy in their homes. A higher percentage of comparison group households reports that they purchase CFLs (73 percent). 
Table 6.2. WAP Clients by Whether Household Purchases CFLs

\begin{tabular}{|c|c|c|}
\hline & Treatment & Comparison \\
\hline Number of Respondents & 656 & 791 \\
\hline Yes & $64 \%$ & $73 \%$ \\
\hline No & $34 \%$ & $25 \%$ \\
\hline Does not know what a CFL is & $2 \%$ & $2 \%$ \\
\hline TOTAL & $100 \%$ & $100 \%$ \\
\hline
\end{tabular}

CFLs should be brought to a local recycling center because they contain a small amount of mercury that should not be introduced into landfills. Table 6.3 shows that only about 19 percent of treatment group clients report that they recycle CFLs; most clients who have disposed bulbs have put them in their regular trash. The comparison group households report a similar pattern, with only 21 percent of households reporting that they recycle CFLs.

Table 6.3. WAP Clients by How Household Disposes of CFLs

\begin{tabular}{|l||c||c||}
\hline \hline How do you dispose of compact fluorescent light bulbs that are broken or no longer working? \\
\hline \hline Number of Respondents & Treatment & Comparison \\
\hline \hline Put directly in household garbage & 612 & 751 \\
\hline Double bagged in plastic & $21 \%$ & $25 \%$ \\
\hline Transported to local recycling center & $16 \%$ & $16 \%$ \\
\hline Have not disposed of yet & $19 \%$ & $21 \%$ \\
\hline Other & $5 \%$ & $9 \%$ \\
\hline Have not purchased/don't know what a CFL is & $1 \%$ & $1 \%$ \\
\hline \hline TOTAL & $39 \%$ & $28 \%$ \\
\hline
\end{tabular}

\subsection{HOT WATER PRACTICES}

A simple way to increase safety in the home and reduce energy use is to reduce the temperature of the hot water heater. Table 6.4 shows that a small proportion of the treatment group households have changed their water heater temperature in the last year, but about nine percent of the households raised the water temperature and about 11 percent lowered the temperature. Reports from comparison group households are very similar to the reports from the treatment group. The survey demonstrates that most clients do not actively change their water heater temperature. 
Table 6.4. WAP Clients by How Household Adjusted Water Heater Temperature in Past 12 Months

\begin{tabular}{|c|c|c|}
\hline & Treatment & Comparison \\
\hline Number of Respondents & 646 & 781 \\
\hline Temperature is much warmer & $2 \%$ & $2 \%$ \\
\hline Temperature is warmer & $7 \%$ & $8 \%$ \\
\hline Temperature is cooler & $10 \%$ & $11 \%$ \\
\hline Temperature is much cooler & $1 \%$ & $1 \%$ \\
\hline Did not adjust & $78 \%$ & $76 \%$ \\
\hline Water heater not working/No water heater & $2 \%$ & $2 \%$ \\
\hline TOTAL & $100 \%$ & $100 \%$ \\
\hline
\end{tabular}

Similarly, by using cold water for clothes washing, a household can reduce energy usage. While 52 percent of treatment group households report using cold water for the wash cycle (Table 6.5) and 79 percent report using cold water for the rinse cycle (Table 6.6), a significant number of households still use warm water. Comparison group households exhibit very much the same pattern of usage as treatment group households.

Table 6.5. WAP Clients by Temperature of Wash Cycle for Home Washing Machine

\begin{tabular}{|c|c|c|}
\hline & Treatment & Comparison \\
\hline Number of Respondents & 658 & 792 \\
\hline Hot & $4 \%$ & $4 \%$ \\
\hline Warm & $37 \%$ & $40 \%$ \\
\hline Cold & $52 \%$ & $51 \%$ \\
\hline Does not have washing machine & $7 \%$ & $5 \%$ \\
\hline TOTAL & $100 \%$ & $100 \%$ \\
\hline
\end{tabular}

Table 6.6. WAP Clients by Temperature of Rinse Cycle for Home Washing Machine

\begin{tabular}{|l|c||c||}
\hline \multicolumn{2}{|l||}{ What water temperature setting is usually used for the rinse cycle of your clothes washer? } \\
\hline \hline & Treatment & Comparison \\
\hline \hline Number of Respondents & 656 & 789 \\
\hline \hline Hot & $1 \%$ & $1 \%$ \\
\hline Warm & $13 \%$ & $12 \%$ \\
\hline Cold & $79 \%$ & $82 \%$ \\
\hline Does not have washing machine & $7 \%$ & $5 \%$ \\
\hline \hline TOTAL & $100 \%$ & $100 \%$ \\
\hline \hline
\end{tabular}


Finally, by taking shorter showers a household also can reduce energy consumption. However, Table 6.7 shows that almost as many households report an increase in shower length in the last year as report a decrease. And, the comparison group of households exhibits the same response pattern.

Table 6.7. WAP Clients by Change in Household Shower Length

\begin{tabular}{|c|c|c|}
\hline & Treatment & Comparison \\
\hline Number of Respondents & 661 & 797 \\
\hline Increased & $10 \%$ & $7 \%$ \\
\hline Decreased & $11 \%$ & $9 \%$ \\
\hline Not changed & $78 \%$ & $83 \%$ \\
\hline No shower & $2 \%$ & $2 \%$ \\
\hline TOTAL & $100 \%$ & $100 \%$ \\
\hline
\end{tabular}

\subsection{OTHER ENERGY EFFICIENCY PRACTICES}

There are some other common energy efficiency practices that can help to reduce energy usage in the home. The Baseline Occupant Survey findings with respect to these items include:

- Energy Star Appliances - About one-third of treatment group households report purchasing Energy Star appliances, but about one-third are not even aware of the Energy Star label (Table 6.8).

- Line Dry Clothes - Almost 40 percent of households report that they sometimes or always line dry clothes (Table 6.9).

Comparison group households did report that they were more likely to purchase Energy Star labeled products, but did not differ from treatment group households in other ways.

Table 6.8. WAP Clients by Whether Household Purchased Items with an Energy Star Label

\begin{tabular}{|c|c|c|}
\hline \multicolumn{3}{|c|}{$\begin{array}{l}\text { Has your household bought or intentionally installed appliances or consumer electronics that have an } \\
\text { Energy Star label? }\end{array}$} \\
\hline & Treatment & Comparison \\
\hline Number of Respondents & 644 & 774 \\
\hline Yes & $40 \%$ & $53 \%$ \\
\hline No & $27 \%$ & $17 \%$ \\
\hline Does not know Energy Star & $34 \%$ & $30 \%$ \\
\hline TOTAL & $100 \%$ & $100 \%$ \\
\hline
\end{tabular}


Table 6.9. WAP Clients by How Often Household Hangs Clothes to Dry

\begin{tabular}{|c|c|c|}
\hline \multicolumn{3}{|c|}{ How frequently does your household hang clothes to dry? } \\
\hline & Treatment & Comparison \\
\hline Number of Respondents & 663 & 800 \\
\hline Very frequently & $17 \%$ & $15 \%$ \\
\hline Frequently & $22 \%$ & $25 \%$ \\
\hline Infrequently & $13 \%$ & $11 \%$ \\
\hline Very infrequently & $13 \%$ & $12 \%$ \\
\hline Never & $36 \%$ & $38 \%$ \\
\hline TOTAL & $100 \%$ & $100 \%$ \\
\hline
\end{tabular}





\section{INDOOR AIR QUALITY RISKS}

This section of the report provides findings from the Baseline Survey on IAQ indicators for WAP clients. There are many potential sources of IAQ problems for low-income households. These include excess moisture that results in mold or mildew in the home, intrusion of pollens and other contaminants from outside the home, and having insects or rodents in the home. While many of these contaminants are difficult to measure, survey responses from treatment and comparison group clients can furnish some indication of their prevalence in the population.

By sealing air leaks, weatherization can also potentially reduce the intrusion of outdoor air into the home. In some areas and at some times of the year, the high amount of pollen and other potential contaminants in the air can pose a health risk for clients with respiratory problems. Table 7.1 shows how much noise clients can hear from outside when the windows are closed. Over one-fourth of treatment group households (28 percent) said that they can hear a great deal and 70 percent of households reported that they could hear some or a great deal. The fact that a household can hear outdoor noise when the windows are closed suggests that the home may be vulnerable to intrusion of pollens and other outdoor contaminants through breaches in the building envelope. Only about 10 percent of comparison group households reported that they could hear a great deal of noise when the windows were closed.

Table 7.1. WAP Clients by Noise Level Indoors ${ }^{9}$

\begin{tabular}{|l|c|c||}
\hline \multicolumn{2}{|l|}{ How much noise do you hear indoors when the windows are closed? } \\
\hline \hline & Treatment & Comparison \\
\hline \hline Number of Respondents & 664 & 801 \\
\hline \hline A great deal & $28 \%$ & $12 \%$ \\
\hline Some & $42 \%$ & $39 \%$ \\
\hline Hardly any & $26 \%$ & $39 \%$ \\
\hline None at all & $4 \%$ & $10 \%$ \\
\hline \hline TOTAL & $100 \%$ & $100 \%$ \\
\hline
\end{tabular}

Tables 7.2 and 7.3 furnish information on client perceptions of the number of insects and rodents in their home. Air leaks in the home also might allow access to household pests. Having insects and/or rodents in the home can result in poor IAQ. Table 7.2 shows that 5.0 percent of clients report that their home was very or extremely infested with cockroaches or other insects or spiders. About one-fourth of households (25 percent) reported that their home was at least somewhat infested. About 16 percent of comparison group households reported that their home was at least somewhat infested. Similarly Table 7.3 shows that 1.7 percent of treatment group households reported that their home was very or extremely infested with rats or mice and 11 percent reported that their home was at least somewhat infested. About six percent of comparison group households reported that their home was at least somewhat infested with rats or mice. These statistics suggest that WAP was responsible for reducing the rate of infestation of both insects and rodents by five to 10 percentage points.

\footnotetext{
${ }^{9}$ Since treatment and comparison households are in the same geographic areas, they are expected to have the same exposure to outdoor noise.
} 
Table 7.2. WAP Clients by Level of Home Insect Infestation

\begin{tabular}{||l||c|c||}
\hline \multicolumn{2}{||l||}{ How infested is your home with cockroaches or other insects or spiders? } \\
\hline \hline & Treatment & Comparison \\
\hline \hline Number of Respondents & 661 & 801 \\
\hline \hline Extremely Infested & $1.8 \%$ & $0.6 \%$ \\
\hline Very Infested & $3.2 \%$ & $1.6 \%$ \\
\hline Somewhat Infested & $20.3 \%$ & $14.0 \%$ \\
\hline Hardly Infested & $24.1 \%$ & $27.3 \%$ \\
\hline Not Infested at All & $50.7 \%$ & $56.4 \%$ \\
\hline \hline TOTAL & $100 \%$ & $100 \%$ \\
\hline \hline
\end{tabular}

Table 7.3. WAP Clients by Level of Home Rodent Infestation

\begin{tabular}{|c|c|c|}
\hline \multicolumn{3}{|c|}{ How infested is your home with rats or mice? } \\
\hline & Treatment & Comparison \\
\hline Number of Respondents & 665 & 802 \\
\hline Extremely Infested & $0.5 \%$ & $0.1 \%$ \\
\hline Very Infested & $1.2 \%$ & $0.5 \%$ \\
\hline Somewhat Infested & $8.7 \%$ & $5.5 \%$ \\
\hline Hardly Infested & $16.2 \%$ & $13.8 \%$ \\
\hline Not Infested at All & $73.4 \%$ & $80.1 \%$ \\
\hline TOTAL & $100 \%$ & $100 \%$ \\
\hline
\end{tabular}

Moisture in the home can lead to the development of mold or mildew. Having mold or mildew in the home can aggravate respiratory problems for vulnerable household members. As part of the delivery of weatherization services, the service delivery agency will assess the sources of moisture in the home and remediate where possible. In some cases, remediation involves changing the way the gutters and downspouts are configured so that water does not come into the home. In other cases, bathrooms and kitchens can be ventilated so that excess moisture is removed from the home. Table 7.4 shows that about 5.3 percent of treatment group households report that their home often or always has standing water, and about 20 percent of households report that this happens at least sometimes. About 10 percent of comparison group households report seeing standing water at least sometimes. This suggests that WAP was responsible for reducing the incidence of moisture problems by 10 to 15 percentage points. 
Table 7.4. WAP Clients by How Often Standing Water Observed in the Home

\begin{tabular}{|l||c||c||}
\hline \hline \multicolumn{1}{||}{ How often do you observe standing water anywhere in your home? } \\
\hline \hline Number of Respondents & Treatment & Comparison \\
\hline \hline Always & 664 & 803 \\
\hline Often & $1.8 \%$ & $1.6 \%$ \\
\hline Sometimes & $3.5 \%$ & $1.4 \%$ \\
\hline Rarely & $14.9 \%$ & $7.0 \%$ \\
\hline Never & $12.5 \%$ & $9.3 \%$ \\
\hline \hline TOTAL & $67.3 \%$ & $80.7 \%$ \\
\hline \hline
\end{tabular}

Table 7.5 shows that about 30 percent of treatment group households reported that their home frequently has a mildew odor or musty smell, and Table 7.6 shows that 28 percent of households reported seeing mold in their home. About 16 percent of comparison group households reported having a mildew odor or musty smell and about 19 percent reported seeing mold. The reduction might be a result, in part, of having better ventilation. Table 7.7 shows that comparison group households were more likely to use exhaust fans when cooking and ventilation fans when showering than treatment group households. These findings suggest that WAP was responsible for reducing the incidence of mold and mildew problems by five to 15 percentage points, and in improving the use of exhaust fans by five to 10 percentage points.

Table 7.5. WAP Clients by Presence of Frequent Mildew Odor in the Home

\begin{tabular}{||l|c|c||}
\hline \hline \multicolumn{2}{|l||}{ Did your home frequently have a mildew odor or musty smell? } \\
\hline \hline Number of Respondents & Treatment & Comparison \\
\hline \hline Yes & 662 & 802 \\
\hline No & $30 \%$ & $16 \%$ \\
\hline \hline TOTAL & $70 \%$ & $84 \%$ \\
\hline \hline
\end{tabular}

Table 7.6. WAP Clients by Presence of Mold in the Home in the Past 12 Months

\begin{tabular}{|l||c||c||}
\hline \multicolumn{2}{|l||}{ Have you seen mold in your home in the past 12 months? } \\
\hline \hline & Treatment & Comparison \\
\hline \hline Number of Respondents & 660 & 799 \\
\hline \hline Yes & $28 \%$ & $19 \%$ \\
\hline No & $72 \%$ & $81 \%$ \\
\hline \hline TOTAL & $100 \%$ & $100 \%$ \\
\hline
\end{tabular}


Table 7.7. Percent of WAP Clients Who Use Exhaust Fans

\begin{tabular}{|l|c|c||}
\hline $\begin{array}{l}\text { Is an exhaust fan that vents to the outside used regularly when cooking in your kitchen? How often } \\
\text { do you or members of your household operate the [exhaust] fan while showering? }\end{array}$ \\
\hline \hline & Treatment & Comparison \\
\hline \hline Number of Respondents & 665 & 803 \\
\hline \hline Use the cooking stove exhaust fan regularly & $41 \%$ & $49 \%$ \\
\hline Had fan operated all the time when showering & $19 \%$ & $28 \%$ \\
\hline
\end{tabular}

It is easier for households to practice setback when they have a programmable thermostat. Table 7.8 shows that about one-fourth of treatment group households had a programmable thermostat before weatherization compared to more than one-third of comparison group households. The share of households with carbon monoxide (CO) monitors and smoke alarms also was higher among comparison group households. WAP subgrantees routinely install ventilation, $\mathrm{CO}$ monitors, and smoke alarms.

Table 7.8. WAP Clients by Heating Thermostat Type

\begin{tabular}{|l||c||c||}
\hline \multicolumn{2}{|l|}{ Is the thermostat that controls your main heating equipment programmable? } \\
\hline \hline & Treatment & Comparison \\
\hline \hline Number of Respondents & 651 & 779 \\
\hline Programmable Thermostat & $24 \%$ & $36 \%$ \\
\hline Manual Thermostat & $64 \%$ & $55 \%$ \\
\hline \hline Noither & $12 \%$ & $10 \%$ \\
\hline \hline
\end{tabular}

Table 7.9. WAP Clients by Presence of Carbon Monoxide Monitors

\begin{tabular}{|l||c||c||}
\hline \multicolumn{2}{|l|}{ Does your home have a working CO monitor? } \\
\hline \hline Number of Respondents & Treatment & Comparison \\
\hline \hline Yes & 642 & 781 \\
\hline No & $46 \%$ & $76 \%$ \\
\hline \hline TOTAL & $54 \%$ & $24 \%$ \\
\hline \hline
\end{tabular}

Table 7.10. WAP Clients by Presence of Smoke Detectors

\begin{tabular}{|l|c|c|}
\hline \multicolumn{2}{|l|}{ Does your home have at least one working smoke detector? } \\
\hline \hline & Treatment & Comparison \\
\hline \hline Number of Respondents & 644 & 795 \\
\hline \hline Yes & $88 \%$ & $96 \%$ \\
\hline No & $12 \%$ & $4 \%$ \\
\hline \hline TOTAL & $100 \%$ & $100 \%$ \\
\hline
\end{tabular}


Table 7.11 summarizes the difference in the rates at which treatment and comparison group households reported these indicators of potential IAQ problems. For most of these indicators, the comparison group households reported that they experienced the problem at one-half the rate that the treatment group did, suggesting that WAP was effective in addressing these issues.

Table 7.11. Summary of WAP Household Health and Safety Findings

\begin{tabular}{|c|c|c|c|}
\hline Indicator & Treatment & Comparison & $\begin{array}{c}\text { Percent } \\
\text { Difference }\end{array}$ \\
\hline Outdoor Noise / A great deal & $28 \%$ & $12 \%$ & $-57 \%$ \\
\hline Very or extremely infested / insects & $5.0 \%$ & $2.2 \%$ & $-56 \%$ \\
\hline Very or extremely infested / rodents & $1.7 \%$ & $0.6 \%$ & $-65 \%$ \\
\hline Standing water / often or always & $5.3 \%$ & $3.0 \%$ & $-43 \%$ \\
\hline Mildew or Musty Smell & $30 \%$ & $16 \%$ & $-47 \%$ \\
\hline Mold & $28 \%$ & $19 \%$ & $-32 \%$ \\
\hline
\end{tabular}





\section{ENERGY AFFORDABILITY}

This section of the report provides findings from the Baseline Survey on energy affordability for WAP clients. For many low income households, energy bills represent a significant share of income, particularly in the winter and summer when heating and cooling needs are the greatest. By reducing the consumption of energy, WAP can make energy bills more affordable and improve the ability of clients to maintain energy service. To the extent that WAP service delivery gives clients a better understanding of their energy usage, it can empower clients to reduce energy usage during times when demands are high or when their income falls short of expectations.

The analysis looks at three different dimensions of energy affordability.

- Difficulty Paying Bills - The analysis first documents what share of WAP clients reported that they had significant problems paying their energy bill. The bills for some clients are particularly high and some clients have substantial expenses for other purposes.

- Payment Strategies - The analysis looks at the different ways that clients address payment problems. While some clients defer bill payments, others make choices to reduce other important expenditures such as paying for prescriptions.

- Service Disruption - The final part of the analysis documents the rate at which clients lost their service and assesses the implications for the clients of service disruption.

The analysis shows that most WAP clients have difficulty paying their energy bills, many clients adopt strategies to pay those bills that can put household members at risk, and some clients experience significant financial and personal hardship resulting from affordability problems. The analysis shows that comparison group households have a lower incidence of affordability problems than do treatment group households, indicating that WAP has some impact on energy affordability. However, the statistics also show that the program does not eliminate all energy affordability problems for all households.

\subsection{BILL PAYMENT}

Table 8.1 shows that almost one-third of treatment group households reported that it is very hard to pay their energy bills and 75 percent report that it is hard or very hard. Fewer comparison group households report that it is very hard for them to pay their energy bills (19 percent) and more (30 percent) report that it is not hard for them to pay their bills. These findings suggest that WAP was responsible for making energy bills significantly more affordable for about 10 to 15 percent of client households. 
Table 8.1. WAP Clients By Level of Difficulty Faced Paying Energy Bills

\begin{tabular}{||l||c||c||}
\hline \hline \multicolumn{2}{||l||}{ How hard is it to pay your energy bills? } \\
\hline \hline Number of Respondents & Treatment & Comparison \\
\hline \hline Very hard & 661 & 795 \\
\hline Hard & $31 \%$ & $19 \%$ \\
\hline Neither hard or not hard & $44 \%$ & $41 \%$ \\
\hline Not hard & $7 \%$ & $11 \%$ \\
\hline Not hard at all & $12 \%$ & $21 \%$ \\
\hline \hline TOTAL & $6 \%$ & $9 \%$ \\
\hline \hline
\end{tabular}

Tables 8.2 through 8.4 furnish some of the reasons that low income households might have to put off paying their energy bills.

- Table 8.2 shows that 35 percent of treatment group households put off paying their energy bills to pay another utility bill at least once in the last 12 months.

- Table 8.3 shows that 28 percent of treatment group households put off paying their energy bill to purchase food at least once in the last 12 months.

- Tables 8.4 shows that 12 percent of treatment group households put off paying their energy bill to purchase prescription medicines at least once in the last 12 months.

These statistics show that many low-income households report that they have to balance what bills to pay to meet their household needs. Comparison group households reported a lower incidence of each of these problems, suggesting that WAP was responsible for reducing or eliminating these problems for five to 10 percent of client households.

Table 8.2. WAP Clients by How Often Household Did Not Pay Energy Bills to Pay Other Utility Bills in Past 12 Months

\begin{tabular}{|l||c||c||}
\hline $\begin{array}{l}\text { Over the past } 12 \text { months, how often has your household not paid energy bills in order to pay other } \\
\text { utility bills? }\end{array}$ & Treatment & Comparison \\
\hline \hline Number of Respondents & 662 & 795 \\
\hline \hline Every month & $3.8 \%$ & $1.6 \%$ \\
\hline Every other month & $5.3 \%$ & $3.9 \%$ \\
\hline Every few months & $10.9 \%$ & $8.6 \%$ \\
\hline Every six months & $6.3 \%$ & $4.9 \%$ \\
\hline Once in twelve months & $8.6 \%$ & $6.2 \%$ \\
\hline Never & $65.1 \%$ & $74.8 \%$ \\
\hline \hline TOTAL & $100 \%$ & $100 \%$ \\
\hline \hline
\end{tabular}


Table 8.3. WAP Clients by How Often Household Did Not Pay Energy Bills in Order to Purchase Food in Past 12 Months

\begin{tabular}{||l||c||c||}
\hline \hline \multicolumn{1}{||l||}{ Over the past 12 months, how often has your household not paid energy bills in order to purchase food? } \\
\hline \hline Number of Respondents & Treatment & Comparison \\
\hline \hline Every month & 661 & 795 \\
\hline Every other month & $1.7 \%$ & $1.5 \%$ \\
\hline Every few months & $3.6 \%$ & $1.9 \%$ \\
\hline Every six months & $9.5 \%$ & $6.2 \%$ \\
\hline Once in twelve months & $5.1 \%$ & $3.9 \%$ \\
\hline Never & $7.6 \%$ & $5.5 \%$ \\
\hline \hline TOTAL & $72.5 \%$ & $81.0 \%$ \\
\hline
\end{tabular}

Table 8.4. WAP Clients by How Often Household Did Not Pay Energy Bills to Purchase Prescription Medicines in the Past 12 Months

\begin{tabular}{|c|c|c|}
\hline \multicolumn{3}{|c|}{$\begin{array}{l}\text { Over the past } 12 \text { months, how frequently has your household not paid energy bills } \\
\text { in order to purchase prescription medicines? }\end{array}$} \\
\hline & Treatment & Comparison \\
\hline Number of Respondents & 664 & 797 \\
\hline Every month & $1 \%$ & $<1 \%$ \\
\hline Every other month & $1 \%$ & $1 \%$ \\
\hline Every few months & $3 \%$ & $3 \%$ \\
\hline Every six months & $2 \%$ & $3 \%$ \\
\hline Once in 12 months & $5 \%$ & $3 \%$ \\
\hline Never & $88 \%$ & $90 \%$ \\
\hline TOTAL & $100 \%$ & $100 \%$ \\
\hline
\end{tabular}

\subsection{AFFORDABILITY STRATEGIES}

Households adopt a variety of strategies to try to pay their energy bills. One option offered by energy suppliers is a budget payment plan. Table 8.5 shows that close to 40 percent of treatment group households report than they use a budget plan. While the budget plan does help to reduce the monthly variation in energy bills, it does not solve the problem for households that have very high energy bills. Moreover, some utilities will not allow clients to enroll in a budget payment plan if they have overdue bills. So, enrolling in a budget payment plan is not always a solution for low-income households. The comparison group households appear to use budget payment plans at about the same rate as the treatment group households. 
Table 8.5. WAP Clients by Whether Household Used a Budget Plan in Past 12 Months

\begin{tabular}{||l|c|c||}
\hline \hline In the past 12 months, did your household use a budget plan for any home energy bill? \\
\hline \hline Number of Respondents & Treatment & Comparison \\
\hline \hline Yes & 658 & 798 \\
\hline No & $39 \%$ & $38 \%$ \\
\hline \hline TOTAL & $61 \%$ & $62 \%$ \\
\hline \hline
\end{tabular}

The most basic strategy for households that are having difficulty paying their energy bills is to simply pay less than the full amount owed. Table 8.6 shows that about one-half of treatment group clients reported that they paid less than the full energy bill at least one month in the last year, and 10 percent reported that they paid less than the full bill almost every month. The comparison group households reported that they were slightly less likely to put off paying their energy bill, but almost 40 percent still report that they paid less than their full bill at least once in the last year.

Table 8.6. WAP Clients by How Often Household Paid Less Than Full Energy Bill Because They Were Unable to Afford Whole Energy Bill in Past 12 Months

\begin{tabular}{|l||c||c||}
\hline $\begin{array}{l}\text { In the past } 12 \text { months, how often did your household pay an amount less than what you owed on your home energy bill } \\
\text { because you were unable to afford the whole home energy bill? }\end{array}$ & Treatment & Comparison \\
\hline \hline Number of Respondents & 663 & 795 \\
\hline \hline Almost every month & $10 \%$ & $10 \%$ \\
\hline Some months & $17 \%$ & $14 \%$ \\
\hline 1 or 2 months & $19 \%$ & $12 \%$ \\
\hline Never & $54 \%$ & $64 \%$ \\
\hline \hline TOTAL & $100 \%$ & $100 \%$ \\
\hline
\end{tabular}

Utility customers do not get a shut-off notice for every unpaid bill. However, Table 8.7 shows that 39 percent of treatment group households reported receiving at least one shutoff notice in the last year. About 20 percent of treatment group households report receiving multiple shutoff notices throughout the year. About 33 percent of comparison group households reported receiving at least one shutoff notice, about six percentage points less than the treatment group. 
Table 8.7. WAP Clients By How Often Received Disconnect Notice in the Past 12 Months

\begin{tabular}{|c|c|c|}
\hline \multicolumn{3}{|c|}{$\begin{array}{l}\text { In the past } 12 \text { months, how often did you receive a disconnect, shut-off, or non-delivery } \\
\text { notice? }\end{array}$} \\
\hline & Treatment & Comparison \\
\hline Number of Respondents & 664 & 799 \\
\hline Almost every month & $7 \%$ & $5 \%$ \\
\hline Some months & $13 \%$ & $9 \%$ \\
\hline 1 or 2 months & $20 \%$ & $19 \%$ \\
\hline Never & $61 \%$ & $67 \%$ \\
\hline TOTAL & $100 \%$ & $100 \%$ \\
\hline
\end{tabular}

Sometimes low-income households make use of short-term high interest loans to pay their energy bills. Table 8.8 shows the different types of loans that treatment group households report having used. About 19 percent of households reported that they used one or more of these loans in the last year. Among comparison group households, only about 12 percent reported using one or more of these loans in the last year.

Table 8.8. Percent of WAP Clients Who Used Short-Term, High Interest Loans to Pay Energy Bills in Past 12 Months

\begin{tabular}{||l||c|c||}
\hline \hline In the past year, have you used any of the following to assist with paying your energy bill? ${ }^{10}$ & Treatment & Comparison \\
\hline \hline Number of Respondents & 660 & 798 \\
\hline \hline Pay day loan & $5.5 \%$ & $3.9 \%$ \\
\hline Tax refund anticipation loan & $6.5 \%$ & $4.0 \%$ \\
\hline Car title loan & $2.4 \%$ & $1.8 \%$ \\
\hline Other type of short term, high interest loan & $2.9 \%$ & $2.4 \%$ \\
\hline Pawn shop & $8.0 \%$ & $4.5 \%$ \\
\hline None of these things & $81.4 \%$ & $88.2 \%$ \\
\hline
\end{tabular}

Nonpayment of energy bills understates the overall problem of energy affordability. Many low-income households go without basic necessities in order to pay their energy bills. Tables 8.9 through 8.12 document some of the sacrifices that low-income households make.

- Table 8.9 shows that 36 percent of treatment group households reported that they put off paying other utility bills in order to pay their energy bill.

- Table 8.10 shows that 23 percent of treatment group households worry about providing nutritious food for their household members; Table 8.11 shows that 33 percent of treatment group households reported that they did not purchase food in order to pay their energy bill.

- Table 8.12 shows that 27 percent of treatment group households reported that they did not purchase prescription medicines in order to pay their energy bill.

The tables also show that fewer comparison group households reported that they have to do without other utilities, food, or prescription medicines to pay energy bills. The difference was about five to 10 percentage points.

\footnotetext{
${ }^{10}$ Table may add up to more than $100 \%$ as respondents could say yes to multiple loan types.
} 
Table 8.9. WAP Clients by How Frequently Household Did Not Pay Other Utility Bills in Order to Pay Primary Energy Bill

Over the past 12 months, how often has your household not paid other utilities in order to pay the primary energy bill?

\begin{tabular}{|l||c||c||}
\hline \hline & Treatment & Comparison \\
\hline \hline Number of Respondents & 659 & 797 \\
\hline \hline Every month & $2 \%$ & $2 \%$ \\
\hline Every other month & $6 \%$ & $3 \%$ \\
\hline Every few months & $12 \%$ & $10 \%$ \\
\hline Every six months & $7 \%$ & $6 \%$ \\
\hline Once in twelve months & $64 \%$ & $5 \%$ \\
\hline Never & $100 \%$ & $74 \%$ \\
\hline TOTAL & $100 \%$ \\
\hline
\end{tabular}

Table 8.10. Percent of WAP Clients Who Faced Food Concerns in Past 4 Weeks

\begin{tabular}{||l||c|c||}
\hline \hline In the past 4 weeks, did you or another household member... \\
\hline \hline & Treatment & Comparison \\
\hline \hline Number of Respondents & 665 & 803 \\
\hline \hline Go without food for 24 hours? & $7 \%$ & $6 \%$ \\
\hline Worry about having nutritious food? & $23 \%$ & $15 \%$ \\
\hline
\end{tabular}

Table 8.11. WAP Clients by How Frequently Household Did Not Purchase Food in Past 12 Months to Pay Energy Bill

\begin{tabular}{|l||c||c||}
\hline \hline \multicolumn{1}{|l||}{ Over the past 12 months, how often has your household not purchased food to pay an energy bill? } \\
\hline \hline Number of Respondents & Treatment & 661 \\
\hline Every month & $6 \%$ & $5 \%$ \\
\hline Every other month & $4 \%$ & $3 \%$ \\
\hline Every few months & $11 \%$ & $6 \%$ \\
\hline Every six months & $5 \%$ & $4 \%$ \\
\hline Once in twelve months & $6 \%$ & $5 \%$ \\
\hline Never & $67 \%$ & $77 \%$ \\
\hline TOTAL & $100 \%$ & $100 \%$ \\
\hline \hline
\end{tabular}


Table 8.12. WAP Clients by How Frequently Household Did Not Fill Prescriptions in Past 12 Months

\begin{tabular}{|c|c|c|}
\hline \multicolumn{3}{|c|}{$\begin{array}{l}\text { Over the past } 12 \text { months, how often did members of your household not fill a } \\
\text { prescription or take less than the full dose of a prescribed medicine in order to pay } \\
\text { the utility bills? }\end{array}$} \\
\hline & Treatment & Comparison \\
\hline Number of Respondents & 662 & 797 \\
\hline Every month & $3 \%$ & $3 \%$ \\
\hline Every other month & $3 \%$ & $2 \%$ \\
\hline Every few months & $9 \%$ & $5 \%$ \\
\hline Every six months & $6 \%$ & $4 \%$ \\
\hline Once in 12 months & $7 \%$ & $5 \%$ \\
\hline Never & $73 \%$ & $81 \%$ \\
\hline TOTAL & $100 \%$ & $100 \%$ \\
\hline
\end{tabular}

\subsection{AFFORDABILITY OUTCOMES}

Some low-income households lose their energy service and suffer even more extreme consequences as a result of energy bill affordability problems. Table 8.13 shows that 13 percent of treatment group households reported losing their electric or natural gas service, or running out of a delivered fuel, because they were unable to pay their energy bill. About nine percent of comparison group households reported service disruption.

Table 8.13. WAP Clients by Service Termination in the Past 12 Months

\begin{tabular}{|c|c|c|}
\hline \multicolumn{3}{|c|}{$\begin{array}{l}\text { In the past } 12 \text { months, was your electricity or natural gas ever disconnected because you were unable } \\
\text { to pay your home energy bill? In the past } 12 \text { months did your fuel oil, kerosene, propane or wood ever } \\
\text { run out because you were unable to pay for a home energy delivery? }\end{array}$} \\
\hline & Treatment & Comparison \\
\hline Number of Respondents & 664 & 798 \\
\hline Yes & $13 \%$ & $9 \%$ \\
\hline Electricity or natural gas & $4 \%$ & $3 \%$ \\
\hline Fuel oil & $10 \%$ & $6 \%$ \\
\hline No & $87 \%$ & $91 \%$ \\
\hline TOTAL & $100 \%$ & $100 \%$ \\
\hline
\end{tabular}

When they lose their primary heating fuel, households sometimes use alternative sources of heat. As a result, the potential for house fires increase by having a portable heater or by using an open flame such as a cooking stove or fireplace for heat. Table 8.14 shows that 1.1 percent of treatment group households reported that a fire stated in their home as a result of using an alternative source of heat. About 0.8 percent of comparison group households reported that a fire started as a result of using an alternative source of heat. 
Table 8.14. WAP Clients by Whether a Fire Resulted from an Alternative Heating Source

\begin{tabular}{|c|c|c|}
\hline \multicolumn{3}{|c|}{$\begin{array}{l}\text { In the past } 12 \text { months did any fire start in your home as a result of using an alternate } \\
\text { heating source, such as space heaters, electric blankets, your kitchen stove or oven, } \\
\text { heating stove, furnace, or your fireplace? }\end{array}$} \\
\hline & Treatment & Comparison \\
\hline Number of Respondents & 665 & 803 \\
\hline Yes & $1.1 \%$ & $0.8 \%$ \\
\hline No & $99.0 \%$ & $99.3 \%$ \\
\hline Total & $100 \%$ & $100 \%$ \\
\hline
\end{tabular}

Over the longer term, households can experience significant disruptions in their lives due to energy affordability problems. Table 8.15 shows that 1.7 percent of treatment group households reported that they had to move at least once in the last five years because the household could not pay the energy bill. Table 8.16 shows that about eight percent of treatment group households reported other major disruptions in the last five years, including evictions, foreclosures, having to move in with friends or family, having to move into a shelter, or experiencing a family separation. Since these statistics are reported over the last five years, it is unlikely that the difference between the treatment group and comparison group can be attributed to the program impact.

Table 8.15. WAP Clients by Whether Household Moved Because Could Not Pay Energy Bills in the Past 5 Years

\begin{tabular}{||l||c||c||}
\hline $\begin{array}{l}\text { Has your household had to move in the past } 5 \text { years because your household could not pay the } \\
\text { energy bills? }\end{array}$ & Treatment & Comparison \\
\hline \hline & 664 & 803 \\
\hline \hline Number of Respondents & $1.7 \%$ & $1.0 \%$ \\
\hline \hline Yes & $98.3 \%$ & $99.0 \%$ \\
\hline \hline TOTAL & $100 \%$ & $100 \%$ \\
\hline
\end{tabular}


Table 8.16. Percent of WAP Households That Experienced Major Disruptions As a Result of Energy Bills in the Past 5 Years

\begin{tabular}{||l||c||c||}
\hline $\begin{array}{l}\text { In the past } 5 \text { years have you or anyone in the household experienced any of the following as a } \\
\text { result of energy bills? }{ }^{11}\end{array}$ & Treatment & Comparison \\
\hline \hline & 665 & 803 \\
\hline \hline Number of Respondents & $0.6 \%$ & $0.3 \%$ \\
\hline Eviction from home & $2.7 \%$ & $2.2 \%$ \\
\hline Moreclosure on mortgage & $3.8 \%$ & $1.6 \%$ \\
\hline Moved into shelter or been homeless & $0.9 \%$ & $0.0 \%$ \\
\hline Family separation & $1.4 \%$ & $1.0 \%$ \\
\hline None of these things & $92.2 \%$ & $95.3 \%$ \\
\hline
\end{tabular}

\subsection{SUMMARY OF FINDINGS}

Tables 8.17 through 8.19 summarize the difference in the rates at which treatment and comparison group households reported energy affordability problems. Table 8.17 shows that both treatment group and comparison group households reported that their energy bills were hard to pay and that they sometimes were unable to pay their energy bills as a result of needing to pay for other utilities, food, or prescriptions. In general, comparison group households reported problems at a rate about 20 percent less than the treatment group households.

Table 8.17. Summary of Findings on WAP Household Bill Payment Problems

\begin{tabular}{|c|c|c|c|}
\hline Affordability Problem & Treatment & Comparison & $\begin{array}{c}\text { Percent } \\
\text { Difference }\end{array}$ \\
\hline Hard or Very Hard to Pay & $75 \%$ & $60 \%$ & $-20 \%$ \\
\hline Needed to Pay Other Utility Bills & $35 \%$ & $25 \%$ & $-29 \%$ \\
\hline Needed to Purchase Food & $28 \%$ & $19 \%$ & $-32 \%$ \\
\hline Needed to Purchase Prescriptions & $12 \%$ & $10 \%$ & $-17 \%$ \\
\hline
\end{tabular}

Table 8.18 shows that both treatment group and comparison group households reported that they needed to adopt strategies to pay their energy bills that could result in either energy service termination or a reduction in the purchase of basic necessities for the households. However, in general, comparison group households reported problems at a rate that was less than for treatment group households. In particular, about 30 percent fewer comparison group households reported that they had to put off paying other utility bills, or purchasing food or prescriptions.

\footnotetext{
${ }^{11}$ Respondents could select more than one response for this question.
} 
Table 8.18. Summary of Findings on WAP Household Bill Payment Strategies

\begin{tabular}{|c|c|c|c|}
\hline Affordability Problem & Treatment & Comparison & $\begin{array}{c}\text { Percent } \\
\text { Difference }\end{array}$ \\
\hline Budget Payment Plan & $39 \%$ & $38 \%$ & $-3 \%$ \\
\hline Pay Less Than Full Bill / 1 month + & $46 \%$ & $36 \%$ & $-22 \%$ \\
\hline Got a Shutoff Notice / 1 month + & $39 \%$ & $33 \%$ & $-15 \%$ \\
\hline Used Short Term, High Interest Loan & $19 \%$ & $12 \%$ & $-37 \%$ \\
\hline Put Off Paying Other Utility Bills & $36 \%$ & $26 \%$ & $-28 \%$ \\
\hline Did Not Purchase Food & $33 \%$ & $23 \%$ & $-30 \%$ \\
\hline Did Not Purchase Prescriptions & $27 \%$ & $19 \%$ & $-30 \%$ \\
\hline
\end{tabular}

Table 8.19 shows that both treatment group and comparison group households reported that energy affordability problems resulted in serious disruptions for the household. The comparison group was less likely to have experienced these problems in the last 12 months than the treatment group. Some items were reported over the last five years. Since comparison group households received weatherization services just one year earlier than treatment group households, weatherization would only be expected to have a small impact on these problems.

Table 8.19. Summary of Findings on WAP Household Energy Affordability Outcomes

\begin{tabular}{|l|c|c|c||}
\hline \hline Affordability Problem & Treatment & Comparison & $\begin{array}{c}\text { Percent } \\
\text { Difference }\end{array}$ \\
\hline \hline Service Disruption & $13 \%$ & $9 \%$ & $-31 \%$ \\
\hline Fire / Alternative Heating Source & $1.1 \%$ & $0.8 \%$ & $-27 \%$ \\
\hline Household Moved & $1.7 \%$ & $1.0 \%$ & N/A \\
\hline Other Major Household Disruption & $8 \%$ & $5 \%$ & N/A \\
\hline
\end{tabular}




\section{HEALTH STATUS AND OUTCOMES}

This section of the report provides findings from the Baseline Survey on health status and outcomes for WAP clients. The analysis looks at three different dimensions for WAP clients:

- Health Insurance and Utilization - One important component of health status is the availability of health insurance and the utilization of health services. The study examined how energy affordability problems affected access to medical care and medicines.

- Respondent Health Status and Outcomes - The survey asked respondents to report on their own health status and outcomes, including the need for medical care for asthma and the number of days of work missed.

- Household Health Status and Outcomes - The survey also asked respondents to report on the health status and outcomes for others in the household.

The analysis shows that clients perceive that high energy bills are one important barrier to getting the medical care and the medicines and prescriptions that they need, even when the household has health insurance. The survey also documented that a significant share of WAP client households have health problems and that those problems can affect the client's ability to work and the participation of the client's children in school. There were some differences between the treatment and control group households in terms of overall physical health, health outcomes associated with asthma, and the impact of health problems on the number of days worked. However, since there are some differences in the demographic make-up of the treatment and comparison group households, the pre/post analysis of treatment group households developed by comparing findings from the Baseline Occupant Survey to the Follow-Up Occupant Survey will furnish better indicators of program impacts.

\subsection{HEALTH INSURANCE AND UTILIZATION}

Table 9.1 shows that a large share of treatment group households ( 85 percent) report that they have some form of health insurance. Since almost half of the households have an elderly person, most of those households should have access to either Medicare and/or Medicaid. Other sources of insurance might include workplace benefits for households with an employed head of household, Medicare or Medicaid benefits for disabled individuals, and low-income health insurance programs in states where such benefits are offered. But, Table 9.2 shows that about 14 percent of these households did have a break in insurance in the last year. The comparison group had a higher insured rate and a lower incidence of a break in coverage; that is likely due to the higher incidence of elderly individuals in the comparison group. 
Table 9.1. WAP Clients by Whether Had Health Insurance Coverage in the Past 12 Months In the past 12 months have you had any kind of health care coverage, including health insurance, prepaid plans such as HMOs, or government plans such as Medicare?

\begin{tabular}{|l||c||c||}
\hline \hline Number of Respondents & Treatment & Comparison \\
\hline \hline Yes & 665 & 802 \\
\hline No & $85 \%$ & $88 \%$ \\
\hline \hline TOTAL & $15 \%$ & $12 \%$ \\
\hline
\end{tabular}

Table 9.2. WAP Clients by Health Insurance Coverage in the Past 12 Months

\begin{tabular}{|l||c||c||}
\hline \hline During the past 12 months, was there any time that you did not have any health insurance coverage? \\
\hline \hline Number of Respondents & Treatment & Comparison \\
\hline \hline Yes - Break in insurance & 665 & 800 \\
\hline Yes - No health insurance & $14 \%$ & $9 \%$ \\
\hline No - Had health insurance all year & $15 \%$ & $12 \%$ \\
\hline \hline TOTAL & $100 \%$ & $79 \%$ \\
\hline \hline
\end{tabular}

Table 9.3 shows that many of the treatment group households had an insurance plan that paid for at least part of the cost of prescriptions. The comparison group had a higher incidence of households with plans that pay for some part of the cost of prescriptions.

Table 9.3. Percent of WAP Clients Who Have a Health Plan That Covers Prescriptions

\begin{tabular}{|c|c|c|}
\hline \multicolumn{3}{|c|}{$\begin{array}{l}\text { Does your health plan pay for at least some of the cost of prescription medicines prescribed } b \text {. } \\
\text { a doctor? }\end{array}$} \\
\hline & Treatment & Comparison \\
\hline Number of Respondents & 660 & 799 \\
\hline Yes & $75 \%$ & $80 \%$ \\
\hline No & $9 \%$ & $8 \%$ \\
\hline No health insurance & $15 \%$ & $12 \%$ \\
\hline TOTAL & $100 \%$ & $100 \%$ \\
\hline
\end{tabular}

A significant portion of treatment group households reported that they could not afford to see a doctor at some time in the last 12 months because of cost. Table 9.4 shows that the incidence is 65 percent of households that do not have health insurance and 19 percent for households that have health insurance of some type. Similarly, Table 9.5 shows that a significant percentage of households ( 41 percent) had difficulty paying medical bills. Rates for the comparison group households are similar, but slightly lower than for the treatment group households. 
Table 9.4. Percent of WAP Households That Could Not Afford to See Doctor in Past 12 Months, by Whether Household Has Insurance

\begin{tabular}{|c|c|c|c|c|}
\hline \multicolumn{5}{|c|}{ Was there a time in the past 12 months when you needed to see a doctor but could not because of cost? } \\
\hline & \multicolumn{2}{|c|}{ Treatment } & \multicolumn{2}{|c|}{ Comparison } \\
\hline & Lack of Coverage & $\begin{array}{c}\text { Health Care } \\
\text { Coverage }\end{array}$ & Lack of Coverage & $\begin{array}{c}\text { Health Care } \\
\text { Coverage }\end{array}$ \\
\hline Number of Respondents & 192 & 473 & 172 & 627 \\
\hline Yes & $65 \%$ & $19 \%$ & $63 \%$ & $15 \%$ \\
\hline No & $35 \%$ & $81 \%$ & $37 \%$ & $85 \%$ \\
\hline TOTAL & $100 \%$ & $100 \%$ & $100 \%$ & $100 \%$ \\
\hline
\end{tabular}

Table 9.5. Percent of WAP Households That Had Problems Paying Medical Bills in Past 12 Months

\begin{tabular}{||l||c||c||}
\hline \hline $\begin{array}{l}\text { During the past } 12 \text { months, have you or other adults in your household had any problems } \\
\text { paying medical bills? }\end{array}$ & Treatment & Comparison \\
\hline \hline Number of Respondents & 664 & 801 \\
\hline \hline Yes & $41 \%$ & $34 \%$ \\
\hline No & $59 \%$ & $66 \%$ \\
\hline \hline TOTAL & $100 \%$ & $100 \%$ \\
\hline
\end{tabular}

Tables 9.6 and 9.7 show the percentage of households that said they needed prescription medicine (Rx) but could not afford it (Table 9.6) and the percentage that reported the need to pay energy bills had an impact on their ability to pay for prescriptions (Table 9.7). Among treatment group households with prescription coverage, 29 percent reported that they could not afford their prescriptions (Table 9.6) and about 25 percent of households with prescription coverage reported that energy bills had an impact on their ability to pay for prescriptions (Table 9.7). For households without prescription coverage, the rates were 46 percent (Table 9.6) and 37 percent (Table 9.7). There seems to be a high overlap between households that reported that they could not afford to pay for their prescriptions and households that attribute that difficulty to high energy bills. Comparison group households are less likely to report that they had to do without prescriptions because they could not afford them. The incidence of problems with paying for prescriptions for comparison group households were 10 to 15 percentage points lower than for treatment group households. 
Table 9.6. Percent of WAP Households That Needed Prescription Medicines, But Couldn't Afford to Buy Them in Past 12 Months, by Whether Prescriptions Are Covered under Insurance

\begin{tabular}{|l||c|c||c|c||}
\hline $\begin{array}{l}\text { Was there a time in the past 12 months when your household members needed prescription medicines but didn't get } \\
\text { them because you couldn't afford it? }\end{array}$ \\
\hline \hline \multicolumn{2}{|c||}{ Treatment } & Comparison \\
\hline \hline & RX Covered & RX not Covered & RX Covered & RX not Covered \\
\hline \hline Number of Respondents & 497 & 162 & 639 & 160 \\
\hline \hline Yes & $29 \%$ & $46 \%$ & $22 \%$ & $32 \%$ \\
\hline No & $71 \%$ & $54 \%$ & $78 \%$ & $68 \%$ \\
\hline \hline TOTAL & $100 \%$ & $100 \%$ & $100 \%$ & $100 \%$ \\
\hline
\end{tabular}

Table 9.7. How Frequently WAP Clients Needed Prescription Medicine, But Used Money to Pay Utility Bill by Whether Household Gets Prescriptions Covered under Insurance

\begin{tabular}{|l||c|c|c|c||}
\hline \hline $\begin{array}{l}\text { Over the past } 12 \text { months, how often did members of your household not fill a prescription or take less than the full does } \\
\text { of a prescribed medicine in order to pay the utility bill? }\end{array}$ & \multicolumn{2}{|c||}{ Treatment } & Comparison \\
\hline \hline & RX Covered & RX not Covered & RX Covered & RX not Covered \\
\hline \hline \multirow{2}{*}{ Number of Respondents } & 497 & 160 & 637 & 157 \\
\hline \hline Every month & $2 \%$ & $5 \%$ & $3 \%$ & $3 \%$ \\
\hline Every other month & $3 \%$ & $4 \%$ & $2 \%$ & $3 \%$ \\
\hline Every few months & $8 \%$ & $14 \%$ & $5 \%$ & $6 \%$ \\
\hline Every six months & $5 \%$ & $8 \%$ & $4 \%$ & $6 \%$ \\
\hline Once in 12 months & $7 \%$ & $6 \%$ & $4 \%$ & $10 \%$ \\
\hline Never & $75 \%$ & $64 \%$ & $84 \%$ & $72 \%$ \\
\hline \hline TOTAL & $100 \%$ & $100 \%$ & $100 \%$ & $100 \%$ \\
\hline \hline
\end{tabular}

\subsection{RESPONDENT HEALTH STATUS AND OUTCOMES}

The Baseline Occupant Survey asked the survey respondent to report on their own physical and mental health. Table 9.8 furnishes information on the number of days of poor physical health and the number of days of poor mental health in the last 30 days. More than one-half of treatment group respondents (55 percent) reported their physical health was not good on one or more days and about one-fourth of the respondents ( 25 percent) reported that their physical health was not good for all 30 days. It also shows that 45 percent of respondents reported one or more days of poor mental health and 15 percent reported poor mental health all 30 days. The comparison group respondents reported similar, but lower rates of poor physical health and almost identical rates of poor mental health. 
Table 9.8. Number of Days WAP Survey Respondent Had Poor Physical or Mental Health in Past 30 Days

\begin{tabular}{|c|c|c|}
\hline \multicolumn{3}{|c|}{ For each of the following, how many days during the past 30 days... } \\
\hline & Treatment & Comparison \\
\hline Number of Respondents ${ }^{12}$ & 665 & 803 \\
\hline \multicolumn{3}{|c|}{ Was your physical health not good (includes physical illness and injury)? } \\
\hline None & $45 \%$ & $48 \%$ \\
\hline $1-15$ days & $24 \%$ & $27 \%$ \\
\hline 16-29 days & $6 \%$ & $6 \%$ \\
\hline All 30 days & $25 \%$ & $19 \%$ \\
\hline \multicolumn{3}{|c|}{ Was your mental health not good? } \\
\hline None & $56 \%$ & $58 \%$ \\
\hline $1-15$ days & $25 \%$ & $24 \%$ \\
\hline 16-29 days & $5 \%$ & $4 \%$ \\
\hline All 30 days & $15 \%$ & $15 \%$ \\
\hline
\end{tabular}

Table 9.9 shows that about one-third of treatment group respondents (32 percent) reported that they got enough rest or sleep every night, while 20 percent reported that they failed to get enough rest or sleep all 30 days of the month. Comparison group respondents were more likely to report that they got enough rest or sleep every night.

Table 9.9. Number of Days WAP Survey Respondent Got Enough Sleep in the Past 30 Days

\begin{tabular}{||l|c||c||}
\hline $\begin{array}{l}\text { For each of the following, how many days during the past 30 days did you feel that you did not get } \\
\text { enough rest or sleep? }\end{array}$ & Treatment & Comparison \\
\hline \hline & 650 & 788 \\
\hline \hline Number of Respondents & $32 \%$ & $39 \%$ \\
\hline $1-15$ days & $37 \%$ & $36 \%$ \\
\hline $16-29$ days & $10 \%$ & $8 \%$ \\
\hline All 30 days & $21 \%$ & $17 \%$ \\
\hline
\end{tabular}

Table 9.10 shows that 48 percent of the treatment group respondents reported that poor health kept them from doing their usual activities. Seventy-four percent of respondents reported that they had at least one day during which they felt healthy and full of energy and 20 percent reported that they felt that way every day. There was almost no difference between the responses of the treatment group and the comparison group in terms of the number of days that poor health kept them from doing their usual activities, but the comparison group did report that there were more days on which they felt healthy and full of energy.

\footnotetext{
12 Those who responded "don't know" or "refused" were excluded from the base. The base for physical health is 648 for treatment and 782 for comparison. The base for mental health is 652 for treatment and 785 for comparison.
} 
Table 9.10. Number of Days WAP Survey Respondent Faced Changes in Ability to Do Work in the Past 30 Days

\begin{tabular}{||l||c||c||}
\hline \multicolumn{2}{||l||}{ For each of the following, how many days during the past 30 days... } \\
\hline \hline \multicolumn{2}{||}{ Comparison } \\
\hline \hline Number of Respondents $^{13}$ & 665 & 803 \\
\hline \hline $\begin{array}{l}\text { did poor physical or mental health kept you from doing your usual activities, such as self-care, work, or } \\
\text { recreation? }\end{array}$ & $52 \%$ & $53 \%$ \\
\hline None & $30 \%$ & $28 \%$ \\
\hline $1-15$ days & $9 \%$ & $6 \%$ \\
\hline $16-29$ days & $10 \%$ & $13 \%$ \\
\hline All 30 days & & $23 \%$ \\
\hline \hline did you feel very healthy and full of energy? & $34 \%$ & $37 \%$ \\
\hline \hline None & $20 \%$ & $17 \%$ \\
\hline $1-15$ days & $20 \%$ & $23 \%$ \\
\hline $16-29$ days & & $26 \%$ \\
\hline All 30 days
\end{tabular}

Tables 9.11 through 9.13 furnish information on the incidence of asthma and the prevalence of asthma symptoms. The findings include:

- Incidence of Asthma - 19 percent of respondents reported that they have had asthma and 14 percent report that they currently have asthma.

- Symptoms of Asthma - 42 percent of respondents that currently have asthma reported that they have had asthma symptoms in the last week and 88 percent reported that they have had asthma symptoms in the last year.

- Asthma Treatment - 19 percent of respondents that currently have asthma reported that they had to go to the hospital or the emergency room for treatment in the last year. But, 13 percent had to have an overnight stay in the hospital.

The comparison group respondents reported a similar incidence of asthma, frequency of asthma symptoms, and hospital or emergency room asthma treatment. However, it is important to note that while comparison group households were as likely to seek medical treatment, only eight percent needed an overnight stay in the hospital, suggesting that they had less severe asthma problems than the treatment group households.

\footnotetext{
${ }^{13}$ Those who responded "don't know" or "refused" were excluded from the base. The base for poor physical or mental health is 650 treatment and 782 comparison. The base for very healthy is 652 treatment and 781 comparison.
} 
Table 9.11. Whether Main WAP Client Has Asthma

\begin{tabular}{|c|c|c|}
\hline & Treatment & Comparison \\
\hline Number of Respondents & 657 & 796 \\
\hline Respondent still has asthma & $14 \%$ & $15 \%$ \\
\hline Respondent had asthma & $5 \%$ & $3 \%$ \\
\hline Respondent has never had asthma & $81 \%$ & $82 \%$ \\
\hline TOTAL & $100 \%$ & $100 \%$ \\
\hline
\end{tabular}

Table 9.12. When WAP Clients Experienced Most Recent Asthma Symptoms

\begin{tabular}{|l|c|c|}
\hline \multicolumn{1}{|l|}{ How long has it been since you last had any symptoms of asthma? } \\
\hline \hline & Treatment & Comparison \\
\hline \hline Number of respondents who still have asthma & 93 & 122 \\
\hline \hline Never & $0 \%$ & $0 \%$ \\
\hline$<1$ day ago & $25 \%$ & $18 \%$ \\
\hline $1-6$ days ago & $17 \%$ & $19 \%$ \\
\hline 1 week - 12 weeks ago & $29 \%$ & $34 \%$ \\
\hline 12 weeks - 1 year ago & $17 \%$ & $16 \%$ \\
\hline 1 - 3 years ago & $5 \%$ & $7 \%$ \\
\hline 3+ years ago & $6 \%$ & $7 \%$ \\
\hline \hline TOTAL & $100 \%$ & $100 \%$ \\
\hline \hline
\end{tabular}

Table 9.13. Percent of WAP Clients Who Faced Medical Emergencies Due to Asthma in the Past 12 Months

During the past 12 months did you have to stay overnight in the hospital or go to an emergency room because of asthma?

\begin{tabular}{|c|c|c|}
\hline & Treatment & Comparison \\
\hline Number of respondents who still have asthma & 93 & 122 \\
\hline Overnight Stay and Emergency Room Visit & $10 \%$ & $7 \%$ \\
\hline Overnight Stay Only & $3 \%$ & $1 \%$ \\
\hline Emergency Room Visit Only & $6 \%$ & $12 \%$ \\
\hline Neither & $81 \%$ & $80 \%$ \\
\hline TOTAL & $100 \%$ & $100 \%$ \\
\hline
\end{tabular}

Table 9.14 looks at the number of days of work missed because of illness or injury among those WAP clients who are working. For this analysis, the table separates those with asthma from those who do not have asthma. Among household where the respondent did not have asthma, 59 percent of clients reported that they did not miss any days of work; on average respondents reported missing 4.4 days of work for 
illness or injury. In comparison, 58 percent of the small group of households where the respondent did have asthma reported missing one or more days of work and averaged 16.1 days of work missed. The comparison group households had a higher rate of absence for households where the respondent did not have asthma, but a much lower rate of absence for households that did have asthma.

Table 9.14. Work Missed By Primary Wage Earner Due to Illness or Injury in WAP Households in the Past 12 Months

\begin{tabular}{|c|c|c|c|c|}
\hline & \multicolumn{2}{|c|}{ Treatment } & \multicolumn{2}{|c|}{ Comparison } \\
\hline & No asthma & Asthma & No asthma & Asthma \\
\hline Number of Respondents Working & 195 & 26 & 218 & 31 \\
\hline No days & $59 \%$ & $42 \%$ & $49 \%$ & $35 \%$ \\
\hline 1-5 days & $26 \%$ & $31 \%$ & $36 \%$ & $45 \%$ \\
\hline 6-10 days & $5 \%$ & $8 \%$ & $7 \%$ & $6 \%$ \\
\hline 11-30 days & $6 \%$ & $4 \%$ & $6 \%$ & $6 \%$ \\
\hline More than 30 days & $3 \%$ & $15 \%$ & $2 \%$ & $6 \%$ \\
\hline Average Days Missed & 4.4 & 16.1 & 5.6 & 8.4 \\
\hline TOTAL & $100 \%$ & $100 \%$ & $100 \%$ & $100 \%$ \\
\hline
\end{tabular}

Table 9.15 looks at the number of days of work missed because of the illness or injury of another person in the household by those WAP clients who are working. About 69 percent of the treatment group households reported that they missed no days for this reason, but on average working households reported missing 1.86 days of work due to the illness or injury of another person in the household. The average number of days missed by the comparison group households was only 1.33 days.

Table 9.15. Work Missed By Primary Wage Earner Due to Illness or Injury of Another Person in WAP Households in the Past 12 Months

\begin{tabular}{|c|c|c|}
\hline & Treatment & Comparison \\
\hline Number of Respondents Working & 187 & 209 \\
\hline No days & $69 \%$ & $68 \%$ \\
\hline 1-5 days & $23 \%$ & $25 \%$ \\
\hline 6-10 days & $4 \%$ & $4 \%$ \\
\hline 11-30 days & $4 \%$ & $2 \%$ \\
\hline More than 30 days & $1 \%$ & $0 \%$ \\
\hline Average Days Missed & 1.86 & 1.33 \\
\hline TOTAL & $100 \%$ & $100 \%$ \\
\hline
\end{tabular}

Table 9.16 illustrates a similar pattern. Respondents with asthma were more likely to report that they had health issues in the past three months, including shortness of breath and headaches. Comparison group 
households reported a similar incidence of shortness of breath, but were much less likely to report the presence of headaches.

Table 9.16. Presence of Health Issues in WAP Households in the Past Three Months

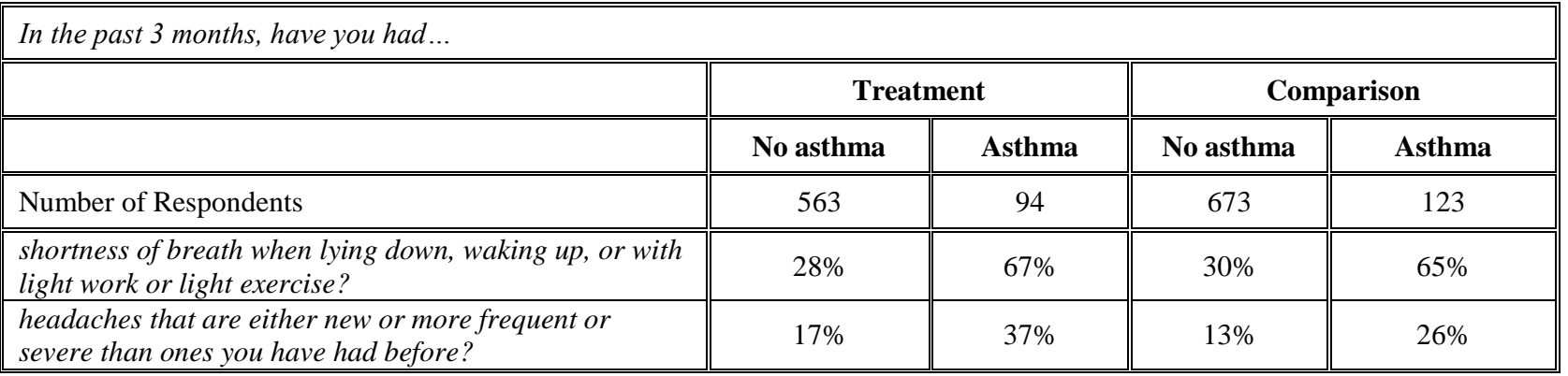

\subsection{HOUSEHOLD HEALTH STATUS AND OUTCOMES}

The Baseline Occupant Survey also asked the survey respondent to report on the physical status of other household members. Table 9.17 shows that a very small percentage of treatment group households reported that one or more individuals in the home had lead poisoning. None of the comparison group households reported lead poisoning.

Table 9.17. Incidence of Lead Poisoning in WAP Households in the Past 12 Months

\begin{tabular}{|c|c|c|}
\hline & Treatment & Comparison \\
\hline Number of Respondents & 663 & 798 \\
\hline No - No one had lead poisoning & $99.7 \%$ & $100.0 \%$ \\
\hline Yes -1 household member & $0.2 \%$ & $0.0 \%$ \\
\hline Yes -2 or more household members & $0.2 \%$ & $0.0 \%$ \\
\hline
\end{tabular}

Table 9.18 shows the incidence of medical issues in the last year that might be related to energy problems, either because of keeping the home too cold or because of IAQ problems. The table shows that a significant share of households reported that one or more individuals had allergies, the flu, persistent cold symptoms, a sinus infection, or bronchitis. The comparison group respondents reported similar or slightly lower rates for all of these illnesses. 
Table 9.18. Percent of Medical Issues in WAP Households in Past 12 Months

\begin{tabular}{|c|c|c|}
\hline \multicolumn{3}{|c|}{$\begin{array}{l}\text { In the past } 12 \text { months, were you or anyone in your household told by a doctor or health professional that } \\
\text { you or they have... }\end{array}$} \\
\hline & Treatment & Comparison \\
\hline Number of Respondents ${ }^{14}$ & 665 & 803 \\
\hline \multicolumn{3}{|l|}{...three or more ear infections per year? } \\
\hline No - No one had $3+$ ear infections & $92.2 \%$ & $92.4 \%$ \\
\hline Yes - 1 household member & $6.0 \%$ & $6.6 \%$ \\
\hline Yes -2 or more household members & $1.8 \%$ & $1.0 \%$ \\
\hline \multicolumn{3}{|l|}{...allergies? } \\
\hline No - No one had allergies & $72.0 \%$ & $76.1 \%$ \\
\hline Yes -1 household member & $22.0 \%$ & $19.2 \%$ \\
\hline Yes -2 or more household members & $6.0 \%$ & $4.8 \%$ \\
\hline \multicolumn{3}{|l|}{...the flu? } \\
\hline No - No one had the flu & $78.4 \%$ & $82.3 \%$ \\
\hline Yes -1 household member & $12.9 \%$ & $11.5 \%$ \\
\hline Yes -2 or more household members & $8.8 \%$ & $6.3 \%$ \\
\hline \multicolumn{3}{|l|}{...persistent cold symptoms lasting more than 14 days? } \\
\hline No - No one had persistent cold & $78.7 \%$ & $80.9 \%$ \\
\hline Yes -1 household member & $17.7 \%$ & $15.8 \%$ \\
\hline Yes -2 or more household members & $3.6 \%$ & $3.4 \%$ \\
\hline \multicolumn{3}{|l|}{... a sinus infection or sinusitis? } \\
\hline No - No one had a sinus infection or sinusitis & $63.3 \%$ & $65.0 \%$ \\
\hline Yes -1 household member & $31.2 \%$ & $29.2 \%$ \\
\hline Yes -2 or more household members & $5.5 \%$ & $5.9 \%$ \\
\hline \multicolumn{3}{|l|}{...bronchitis? } \\
\hline No - No one had bronchitis & $76.9 \%$ & $76.9 \%$ \\
\hline Yes -1 household member & $19.9 \%$ & $20.1 \%$ \\
\hline Yes -2 or more household members & $3.2 \%$ & $2.3 \%$ \\
\hline
\end{tabular}

Table 9.19 shows the rate at which certain types of illness or injuries were experienced. A very small percentage of treatment group respondents reported that someone in their home had food poisoning (1.1 percent), carbon monoxide poisoning ( 0.2 percent), or was burned from water coming out of the showerhead or faucet (1.1 percent). The comparison group respondents reported a lower incidence for two of these three risks.

\footnotetext{
${ }^{14}$ Those who responded "don't know" or "refused" were excluded from the base. The base for three or more ear infections is 662 for treatment and 801 for comparison. The base for allergies is 663 for treatment and 798 for comparison. The base for the flu is 661 for treatment and 800 for comparison. The base for cold is 662 for treatment and 799 for comparison. The base for sinus infection is 660 for treatment and 799 for comparison. The base for bronchitis is 659 for treatment and 798 for comparison.
} 
Table 9.19. Percent of WAP Clients Who Experienced Illness or Injury in the Past 12 Months

\begin{tabular}{|c|c|c|}
\hline & Treatment & Comparison \\
\hline Number of Respondents & 665 & 803 \\
\hline $\begin{array}{l}\text {...food poisoned from eating food inside your home and therefore } \\
\text { went to see a medical professional? }\end{array}$ & $1.1 \%$ & $0.3 \%$ \\
\hline $\begin{array}{l}\text {...poisoned by breathing in carbon monoxide, and therefore went to } \\
\text { see a medical professional? }\end{array}$ & $0.2 \%$ & $0.3 \%$ \\
\hline $\begin{array}{l}\text {...burned from scalding hot water coming out of a faucet or } \\
\text { showerhead in your home? }\end{array}$ & $1.1 \%$ & $0.3 \%$ \\
\hline
\end{tabular}

Table 9.20 shows respondent reports for school missed by a school-aged child in the household. About 60 percent of the respondents reported that their children missed one week or less of school; 20 percent reported that a child missed more than two weeks of school. For the comparison group respondents, 64 percent reported that the children missed one week or less of school; 16 percent reported that a child missed more than two weeks of school.

Table 9.20. Percent of School Missed By School-Aged Child Due to Illness or Injury in the Past 12 Months in a WAP Household

\begin{tabular}{|c|c|c|}
\hline \multicolumn{3}{|c|}{$\begin{array}{l}\text { Please tell us about the school-aged child who has missed the most school days due to illness or injury in } \\
\text { the past } 12 \text { months. How many days of school did that child miss? }\end{array}$} \\
\hline & Treatment & Comparison \\
\hline $\begin{array}{l}\text { Number of respondents who have a school aged child who is in } \\
\text { school }\end{array}$ & 187 & 192 \\
\hline No days & $21 \%$ & $19 \%$ \\
\hline $1-5$ days & $40 \%$ & $46 \%$ \\
\hline 6-10 days & $18 \%$ & $19 \%$ \\
\hline 11-30 days & $17 \%$ & $12 \%$ \\
\hline More than 30 days & $4 \%$ & $4 \%$ \\
\hline TOTAL & $100 \%$ & $100 \%$ \\
\hline
\end{tabular}

\subsection{SUMMARY OF FINDINGS}

Tables 9.21 and 9.22 summarize the different rates at which treatment and comparison group households reported on their health insurance coverage, difficulties in receiving medical treatment or purchasing prescriptions, and their health status.

Table 9.21 shows that most of the treatment and comparison group households have health insurance coverage. This is likely to be due to the high percentage of WAP clients who would qualify for Medicare and/or Medicaid. Nonetheless, it is clear that for significant percentages of both groups, health care costs are a burden. A significant minority of households reported deferring health care treatments or prescriptions in order to pay a utility bill. Comparison group households reported fewer instances when payments were a problem or treatments deferred because of payments to utility companies. 
Table 9.21. Summary of Select Findings on Health Insurance Coverage and Difficulty Paying Medical Costs

\begin{tabular}{|c|c|c|c|}
\hline Medical Costs Problem & Treatment & Comparison & $\begin{array}{l}\text { Percent } \\
\text { Difference }\end{array}$ \\
\hline Health care coverage available & $85 \%$ & $88 \%$ & $+3 \%$ \\
\hline Have coverage but deferred treatment due to cost & $19 \%$ & $15 \%$ & $-21 \%$ \\
\hline No coverage, deferred treatment due to cost & $81 \%$ & $85 \%$ & $+4 \%$ \\
\hline Difficulty paying medical bills & $41 \%$ & $34 \%$ & $-17 \%$ \\
\hline Difficulty paying prescription costs, $\mathrm{Rx}$ coverage & $29 \%$ & $22 \%$ & $-24 \%$ \\
\hline Difficulty paying prescription costs, no $\mathrm{Rx}$ coverage & $46 \%$ & $32 \%$ & $-30 \%$ \\
\hline $\begin{array}{l}\text { Deferred prescriptions to cover utility costs every few months or more often, } \\
\text { Rx covered }\end{array}$ & $13 \%$ & $10 \%$ & $-23 \%$ \\
\hline $\begin{array}{l}\text { Deferred prescriptions to cover utility costs every few months or more often, } \\
\text { Rx not covered }\end{array}$ & $23 \%$ & $12 \%$ & $-48 \%$ \\
\hline
\end{tabular}

Table 9.22 furnishes selected findings on the health status of WAP households. Among treatment group households, 31 percent reported having poor physical health in 15 or more of the last 30 days and 20 percent reported having poor mental health in 15 or more of the last 30 days. The comparison group households showed a lower rate of poor physical health and a similar rate of poor mental health. The share of respondents with asthma was about the same between the treatment and comparison groups, but treatment group households with asthma reported having an overnight stay in the hospital at a higher rate than comparison group households. Among those working, treatment group households without asthma had a lower average number of days missed from work due to their own illness or injury, while for those with asthma the treatment group households had a higher average number of days missed from work due to illness or injury. Treatment group households also had a higher average number of days missed due to the illness or injury of others in the household and children in treatment group households were more likely to miss six or more days of school. These statistics suggest that WAP may have had some impact on health status and productivity for participating households. However, since there are some differences in the demographic make-up of the treatment and comparison group households, the pre/post analysis of treatment group households developed by comparing findings from the Baseline Occupant Survey to the Follow-Up Occupant Survey will furnish better indicators of program impacts.

Table 9 22. Summary of Select Findings on Health Status and Outcomes

\begin{tabular}{|c|c|c|c|}
\hline Health Status Indicator & Treatment & Comparison & $\begin{array}{l}\text { Percent } \\
\text { Difference }\end{array}$ \\
\hline Poor physical health $15+$ days per month & $31 \%$ & $23 \%$ & $-25 \%$ \\
\hline Poor mental health $15+$ days per month & $20 \%$ & $19 \%$ & $-5 \%$ \\
\hline Incidence of Asthma & $14 \%$ & $15 \%$ & $+7 \%$ \\
\hline Asthma Symptoms within preceding 12 weeks & $71 \%$ & $71 \%$ & $\mathrm{NC}$ \\
\hline $\begin{array}{l}\text { Households with overnight hospital stay for asthma (among } \\
\text { those currently with asthma) }\end{array}$ & $13 \%$ & $8 \%$ & $-39 \%$ \\
\hline $\begin{array}{l}\text { Households with emergency room visit for asthma (among } \\
\text { those currently with asthma) }\end{array}$ & $16 \%$ & $19 \%$ & $+19 \%$ \\
\hline
\end{tabular}




\begin{tabular}{|c|c|c|c|}
\hline Health Status Indicator & Treatment & Comparison & $\begin{array}{l}\text { Percent } \\
\text { Difference } \\
\end{array}$ \\
\hline $\begin{array}{l}\text { Households missing work due to illness or injury (among } \\
\text { those working / respondent does not have asthma) }\end{array}$ & 4.41 days & 5.56 days & $+26 \%$ \\
\hline $\begin{array}{l}\text { Households missing work due to illness or injury (among } \\
\text { those working / respondent has asthma) }\end{array}$ & 16.00 days & 8.42 days & $-48 \%$ \\
\hline $\begin{array}{l}\text { Households missing work due to illness or injury of others } \\
\text { in the household (among those working) }\end{array}$ & 1.86 days & 1.33 days & $-29 \%$ \\
\hline $\begin{array}{l}\text { Households with children who missed } 5 \text { or more school } \\
\text { days due to illness or injury }\end{array}$ & $39 \%$ & $35 \%$ & $-10 \%$ \\
\hline
\end{tabular}





\title{
APPENDIX A. BASELINE OCCUPANT SURVEY INSTRUMENT
}

\section{National Weatherization Assistance Program Evaluation Occupant Survey}

Hello. May I please speak to [INSERT CLIENT NAME FROM SAMPLE]?

(IF CLIENT NOT AVAILABLE): Is there another head of household or spouse who is available?

(IF HEAD OF HOUSEHOLD OR SPOUSE NOT AVAILABLE): When would be a good time to call back?

[WHEN CLIENT OR OTHER HEAD OF HOUSEHOLD ON THE PHONE OR IF SOMEONE ASKS WHAT THE CALL IS ABOUT, READ:

This is (INTERVIEWER) from (PHONE CENTER), calling on behalf of the National Weatherization Assistance Program Evaluation.

[IF CONTROL: We are talking to clients who have received weatherization services.]

[IF TREATMENT: We are talking to clients who have applied for weatherization services].

You have been selected to participate in a study that will help us understand how the

Weatherization program [IF CONTROL: has helped/IF TREATMENT: can help] you and how the program can be improved.

In appreciation of your time, we will send you a $\$ 20$ check for completing this survey. You may have already received a letter in the mail explaining the purpose of this study. [IF RESPONDENT ASKS ABOUT LENGTH: This survey will take about 45 minutes.]

\section{IF NECESSARY:}

- We received your name from [INSERT AGENCY NAME], to be used as part of a national sample of weatherization clients.

- All of the information obtained from this survey will be protected and will remain confidential. The data will be analyzed in such a way that the information provided cannot be associated back to you or your household. Your answers will not be shared with or reported back to anyone within the agency that served you or your state.

- Please contact Jen Frenett at APPRISE toll-free 888-434-8008 if you have any questions about the survey.

[IF RESPONDENT DIFFERENT FROM CLIENT IN SAMPLE, ASK S1, OTHERWISE SKIP TO S4]

S1. May I please have your name? RECORD:

96 REFUSED

99 DON'T KNOW/NOT SURE

S2. Are you the head of household or spouse? (INTERVIEWER NOTE: if the head of household or spouse is disabled, a proxy may answer)

\author{
01 YES - CONTINUE WITH INTERVIEW \\ $02 \mathrm{NO}$ \\ 03 PROXY ANSWERS FOR HEAD OF HOUSEHOLD \\ 96 REFUSED \\ 99 DON'T KNOW/NOT SURE
}


IF S2=02, 96, 99 OR S1=96/99:

S3. When can we schedule a time to speak with the head of household or spouse? (SCHEDULE A TIME.)

\section{[ASK S4 IF TREATMENT. DO NOT ASK FOR ANY LARGE MULTI-FAMILY RESPONDENTS]}

S4. First, have you had a home energy audit or assessment conducted by your local agency in the past month or so? During an audit or assessment, a person from your agency comes to your home to look at your home and heating equipment to see what they can do to reduce the energy used in your home. 01 YES - TERMINATE: Unfortunately, you do not qualify for this survey. Thank you for $02 \mathrm{NO}-\mathrm{CONTINUE}$ your time, and have a nice day.

\section{[ASK S5 IF CONTROL]}

S5: Our records show that your current address is: [INSERT ADDRESS FROM SAMPLE]. Can you confirm that's the correct address?

01 YES - CONTINUE

02 NO - TERMINATE: Unfortunately, you not qualify for this survey. Thank you for your time, and have a nice day.

\section{A. HOME HEATING AND COOLING}

A1. Which of the following do you believe best describes your current home? Is it a... (READ)

(INTERVIEWER: DEFINE EACH HOUSING TYPE IF NEEDED:

Single-family detached: a free-standing house for one household. This type of house does not share any walls with another household.

Single-family attached: For example, a townhouse, row house, or duplex. This type of house shares a side wall with another household. Your home is not this type if there are any households that live above or below your living space.

Apartment building with 2-4 units - An apartment building with living spaces for 2, 3, or 4 households. Apartment building with 5 or more units - An apartment building with living spaces for 5 or more households.)

01 Single-family detached house

02 Single-family attached house,

03 Apartment building with 2-4 units

04 Apartment building with 5 or more units

05 Mobile home

96 REFUSED

99 DON'T KNOW/NOT SURE

A2. How many bedrooms do you have in your home? Include bedrooms in finished attics or finished basements.

01 RESPONDENT GAVE NUMBER Enter number

96 REFUSED

99 DON'T KNOW/NOT SURE 
A3. Now think about other rooms in your home besides bedrooms and bathrooms. Not including unfinished areas, hallways, and closets, how many other rooms are there in your home?

\section{RESPONDENT GAVE NUMBER \\ Enter number \\ 96 REFUSED \\ 99 DON'T KNOW/NOT SURE}

A4. Is your home heated during the winter?

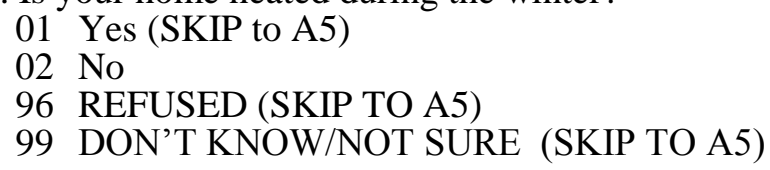

01 Yes (SKIP to A5)

02 No

96 REFUSED (SKIP TO A5)

99 DON'T KNOW/NOT SURE (SKIP TO A5)

A4a. $\{$ IF A4=02 $\}$ You have just told me that you don't heat your home during the winter. Just to clarify, is it that you have heating equipment but don't use it, or does your home just not have any heating equipment?

01 Have equipment, but don't use it (SKIP to A6 )

02 Don't have any heating equipment (SKIP TO A6)

96 REFUSED (SKIP TO A6)

99 DON'T KNOW/NOT SURE (SKIP TO A6)

A5. Last winter, did you heat all ___ (INSERT SUM OF A2 AND A3) rooms?

01 Yes (SKIP to A6)

02 No

96 REFUSED (SKIP TO A6)

99 DON'T KNOW/NOT SURE (SKIP TO A6)

A5a. How many of those rooms were NOT heated last winter?

01 RESPONDENT GAVE NUMBER

Enter the number

96 REFUSED

99 DON'T KNOW/NOT SURE

A6. Is any air conditioning equipment used in your home?

01 Yes (SKIP to A7)

02 No

96 REFUSED (SKIP TO A7)

99 DON'T KNOW/NOT SURE (SKIP TO A7)

A6a. (IF A6=02) Just to clarify, do you have air conditioning equipment but don't use it, or does your home just not have any air conditioning equipment?

01 Have equipment, but don't use it (SKIP to A8)

02 Don't have any air conditioning equipment (SKIP TO A8)

96 REFUSED (SKIP TO A8)

99 DON'T KNOW/NOT SURE (SKIP TO A8)

A7. Last summer, did you air condition all (INSERT SUM OF A2 AND A3) rooms?

01 Yes (SKIP to A8)

02 No

96 REFUSED (SKIP TO A8) 
A7a.How many of those rooms were NOT cooled last summer?

01 RESPONDENT GAVE NUMBER

Enter the number

96 REFUSED

99 DON'T KNOW/NOT SURE

A8. Is any part of your home over a crawl space with exposed dirt as the floor?

01 Yes

02 No

96 REFUSED

99 DON'T KNOW/NOT SURE

A9. Is any part of your home over a basement?

01 Yes

02 No (SKIP TO A10)

96 REFUSED (SKIP TO A10)

99 DON'T KNOW/NOT SURE (SKIP TO A10)

A9a. Do you use your basement for living space? That is, do you use it for work, play or sleep?

01 Yes

02 No (SKIP to A10)

96 REFUSED (SKIP TO A10)

99 DON'T KNOW/NOT SURE (SKIP TO A10)

A9b. Is the basement warm enough to be used as a living space in the winter?

01 Yes

02 No

96 REFUSED

99 DON'T KNOW/NOT SURE

A9c. Is the basement cool enough to be used as a living space in the summer?

01 Yes

02 No

96 REFUSED

99 DON'T KNOW/NOT SURE

A10. An attic is an area directly below the roof, accessible by stairs, with space for you to stand upright and easily move about. Does your home have an attic?

01 Yes

02 No (SKIP to A11)

96 REFUSED (SKIP TO A11)

99 DON'T KNOW/NOT SURE (SKIP TO A11) 
A10a. Do you use the attic for living space? That is, do you use it for work, play or sleep?

01 Yes

02 No (SKIP to A11)

96 REFUSED (SKIP TO A11)

99 DON'T KNOW/NOT SURE (SKIP TO A11)

A10b. Is the attic warm enough to be used as a living space in the winter?

01 Yes

02 No

96 REFUSED

99 DON'T KNOW/NOT SURE

A10c. Is the attic cool enough to be used as a living space in the summer?

01 Yes

02 No

96 REFUSED

99 DON'T KNOW/NOT SURE

A11. Does your home have a garage that is attached to or part of your home?

01 Yes

02 No (SKIP to A12)

96 REFUSED (SKIP TO A12)

99 DON'T KNOW/NOT SURE (SKIP TO A12)

A11a. Do you warm up your vehicle in your garage?

01 Yes

02 No

96 REFUSED

99 DON'T KNOW/NOT SURE

A11b. Have you or anyone else living in your home observed the smell of vehicle exhaust inside your home?
01 Yes
02 No
96 REFUSED
99 DON'T KNOW/NOT SURE

Now I have some questions about heating your home.

A12. \{IF A4=02 SKIP TO A23 $\}$ Let's start with the main source of heating in your home. Please tell me which type of heating equipment provides most of the heat for your home. Remember to include portable heaters, fireplaces, heating stoves and cooking stoves. (READ LIST IF NECESSARY, ACCEPT ONE

RESPONSE ONLY)

01 Heat pump

02 Central furnace with ducts to individual rooms

03 Steam/Hot water system with radiators or pipes in each room

04 Built-in electric units in each room installed in walls, ceilings, baseboards, or floors

05 Built-in floor/wall pipeless furnace

06 Built-in room heater burning gas, oil, or kerosene

07 Heating stove burning wood, coal, or coke

08 Portable heaters 
09 Fireplace

10 Cooking stove used to heat your home as well as to cook

97 SOME OTHER EQUIPMENT (SPECIFY

96 REFUSED

99 DON'T KNOW/NOT SURE

A13. Does the main heating equipment for your home also heat any other apartments, condos, households, businesses, or farm buildings?
01 Yes
02 No
96 REFUSED
99 DON'T KNOW/NOT SURE

A14. What is the main fuel used for heating your home? That is, which fuel is the one that provides the most heat for your home? (READ LIST IF NECESSARY, ACCEPT ONE RESPONSE
ONLY)
01 Electricity
02 Natural gas from underground pipes
03 Propane (bottled gas)
04 Fuel oil
05 Kerosene
06 Wood
07 Biomass
08 Solar or Wind
09 Geothermal
10 District steam
97 SOME OTHER FUEL (SPECIFY
96 REFUSED
99 DON'T KNOW/NOT SURE

SKIP IF A12=96/99

A15. You told me that the [INSERT A12] is the main source of heat in your home. In the past 12 months, did you use any other types of heating equipment? Remember to include portable heaters, fireplaces, heating stoves and cooking stoves.

01 NO OTHER EQUIPMENT

02 YES, I HAVE OTHER EQUIPMENT

96 REFUSED

99 DON'T KNOW/NOT SURE

ASK IF A15=02

A15a. What other types of heating equipment did you use in the past 12 months? [READ LIST IF NECESSARY, CHECK ALL THAT APPLY)

01 Heat pump

02 Central furnace with ducts to individual rooms

03 Steam/Hot water system with radiators or pipes in each room

04 Built-in electric units in each room installed in walls, ceilings, baseboards, or floors

05 Built-in floor/wall pipeless furnace

06 Built-in room heater burning gas, oil, or kerosene

07 Heating stove burning wood, coal, coke, or biomass (such as pellets or corn)

08 Portable heaters

09 Fireplace

10 Cooking stove used to heat your home as well as to cook 
97 SOME OTHER EQUIPMENT (SPECIFY

96 REFUSED

99 DON'T KNOW/NOT SURE

ASK FOR EACH RESPONSE 01-11 IN A15a

A16. What fuel does the [FILL:A15a] use? (READ IF NECESSARY)

01 Electricity

02 Natural gas from underground pipes

03 Propane (bottled gas)

04 Fuel oil

05 Kerosene

06 Wood

07 Biomass (wood pellets or corn)

08 Solar or Wind

09 Geothermal

10 District steam

97 SOME OTHER FUEL (SPECIFY

96 REFUSED

99 DON'T KNOW/NOT SURE

A17. $\{$ IF A14=08 OR A16=08 $\}$

Do you have any on-site system that generates electricity such as a solar system or a small wind turbine?

01 Yes

02 No (SKIP to A18)

96 REFUSED (SKIP TO A18)

99 DON'T KNOW/NOT SURE (SKIP TO A18)

A17a. What type of on-site system do you have? (READ IF NECESSARY)

01 Solar or Photovoltaic system

02 Small wind turbine

03 Combined Heat and Power system

97 OTHER . PLEASE SPECIFY

96 REFUSED

99 DON'T KNOW/NOT SURE

A17b. Is your on-site system connected to the grid?

01 Yes

02 No

96 REFUSED

99 DON'T KNOW/NOT SURE

A18. $\{$ IF A12=07 OR A15a=07 $\}$ Do you have an Energy Star labeled heating stove?

01 Yes

02 No

96 REFUSED

99 DON'T KNOW/NOT SURE

SKIP IF A18=01 
A18a. Was your heating stove manufactured before 1992?

01 Yes

02 No

96 REFUSED

99 DON'T KNOW/NOT SURE

A19. $\{$ IF A12=09 OR A15a=09 $\}$ Does your fireplace have a flue to the outside or is it entirely selfcontained?

01 Flue to the outside

02 Self-contained (Flueless)

96 REFUSED

99 DON'T KNOW/NOT SURE

A20. $\{$ IF A12=07 OR 09 OR A15a=07 OR 09 $\}$ In the past 12 months how often did you have to burn garbage, cardboard, plastics, foam, colored ink, magazines, boxes, or wrappers to keep warm? (READ)
01 Never
02 Once
03 Sometimes
04 Often
05 Most of the winter
96 REFUSED
99 DON'T KNOW/NOT SURE

A21. $\{$ IF A12=07 OR 09 OR A15a=07 OR 09 $\}$ In the past 12 months how often did you have to burn coated, painted, or pressure-treated wood, driftwood, plywood, particle board, or any wood with glue in it to keep warm? (READ)
01 Never
02 Once
03 Sometimes
04 Often
05 Most of the winter
96 REFUSED
99 DON'T KNOW/NOT SURE

A22. $\{$ IF A12=07 OR 09 OR A15a=07 OR 09 $\}$ In the past 12 months how often did you have to burn wet, rotted, diseased, or moldy wood to keep warm? (READ)
01 Never
02 Once
03 Sometimes
04 Often
05 Most of the winter
96 REFUSED
99 DON'T KNOW/NOT SURE

A23. What fuel does the cooking stove and/or oven use? (READ IF NECESSARY) CHECK ALL THAT APPLY

01 Electricity

02 Natural gas from underground pipes

03 Propane (bottled gas)

04 Fuel oil 


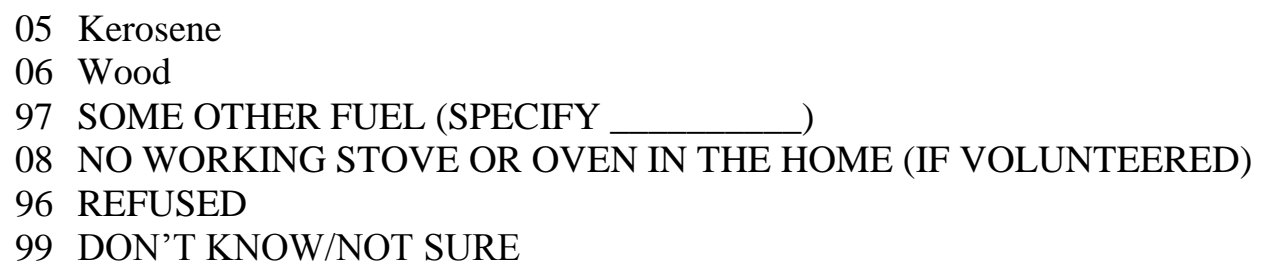

A24. Is an exhaust fan that vents to the outside used regularly when cooking in your kitchen?

01 Yes

02 No

96 REFUSED

99 DON'T KNOW/NOT SURE

IF A4=02, SKIP A25

A25. In the past 12 months how often have you used your oven to heat your house? (READ)

01 Never

02 Rarely

03 Sometimes

04 Frequently

05 All the time

96 REFUSED

99 DON'T KNOW/NOT SURE

A26. Does your household use a microwave oven?

01 Yes

02 No (SKIP to A27)

96 REFUSED (SKIP TO A27)

99 DON'T KNOW/NOT SURE (SKIP TO A27)

A26a. Which statement best describes how frequently your household uses the microwave to prepare hot meals and snacks in a typical week? The microwave is...[INSERT ITEM] (READ)

01 Used to cook or reheat most meals and snacks

02 Used to cook or reheat about half of meals and snacks

03 Used to cook or reheat $a$ few meals and snacks

04 Used very little

96 REFUSED

99 DON'T KNOW/NOT SURE

IF A4=02, SKIP A27-A28a

A27. Does your heating system have an air filter? [INTERVIEWER NOTE: HEATING SYSTEM CAN BE THE PRIMARY OR SECONDARY HEATING SOURCE.]

01 Yes

02 No (SKIP to A28)

96 REFUSED (SKIP TO A28)

99 DON'T KNOW/NOT SURE (SKIP TO A28) 
A27a. Is the air filter in your heating system a High Efficiency Particulate Arresting (HEPA) filter?

01 Yes

02 No

96 REFUSED

99 DON'T KNOW/NOT SURE

A27b. Approximately how often does someone in your household change or clean the air filter in your heating system? (READ)

01 Monthly

02 Every three months

03 Every six months

04 Once a year

05 Once every two years

06 DON'T CHANGE (OR CLEAN) IT (IF VOLUNTEERED)

07 AIR FILTER IS CHANGED BY SERVICE COMPANY (IF VOLUNTEERED)

96 REFUSED

99 DON'T KNOW/NOT SURE

A28. $\{$ IF A12 $=02$ OR A15a=02 $\}$ Do you know when was the last time your furnace received maintenance service by a furnace contractor to ensure optimum and safe operation?

01 Yes

02 No (SKIP to A29)

03 NEVER (IF VOLUNTEERED) (SKIP TO A29)

96 REFUSED (SKIP TO A29)

99 DON'T KNOW/NOT SURE (SKIP TO A29)

A28a. How many years and months ago did this occur?

\{If less than one year $\}$ Enter: months

Enter: years

96 REFUSED

99 DON'T KNOW/NOT SURE

A29. Do you have a CO (or carbon monoxide) monitor in your house?

01 Yes

02 No (SKIP to A30)

96 REFUSED (SKIP TO A30)

99 DON'T KNOW/NOT SURE (SKIP TO A30)

A29a. Is your CO monitor currently working?

01 Yes

02 No

96 REFUSED

99 DON'T KNOW/NOT SURE

A30. Do you have one or more smoke detectors in your house?

01 Yes

02 No (SKIP to A31)

96 REFUSED (SKIP TO A31)

99 DON'T KNOW/NOT SURE (SKIP TO A31) 
A30a. How many smoke detectors are there in your house?

01 RESPONDENT GAVE NUMBER

Enter Number

96 REFUSED

99 DON'T KNOW

A30b. How many of these smoke detectors are currently working?

01 RESPONDENT GAVE NUMBER

Enter Number

96 REFUSED

99 DON'T KNOW/NOT SURE

A31. In the past 12 months how many times has the fire department been called to put out a fire in your home?

\author{
01 RESPONDENT GAVE NUMBER \\ Enter Number \\ 96 REFUSED \\ 99 DON'T KNOW/NOT SURE
}

A32. In the past 12 months did any fire start in your home as a result of using an

alternate heating source, such as space heaters, electric blankets, your kitchen stove or oven, heating

stove, furnace, or your fireplace?

01 Yes

02 No

96 REFUSED

99 DON'T KNOW/NOT SURE

A33. In the past 12 months, how many individuals needed medical attention because of fire?

01 RESPONDENT GAVE NUMBER

96 REFUSED

Enter Number

99 DON'T KNOW/NOT SURE

Now I have some questions about cooling your home.

A34. (IF A6=02 SKIP TO CEILING FAN USE A37) Central air conditioning requires that the system have ducts to carry the cooled air to the individual rooms. These ducts may also carry warm air for space heating. Does your home have ducts like these?

01 Yes

02 No (SKIP to A35)

96 REFUSED (SKIP TO A35)

99 DON'T KNOW/NOT SURE (SKIP TO A35)

A34a. Does the central air conditioning equipment that cools your home also cool any other apartments, condos, households, businesses, or farm buildings?

01 Yes

02 No

96 REFUSED

99 DON'T KNOW/NOT SURE 
A34b. Which of the following statements best describes the way your central air conditioning system was used last summer? The central air conditioning was...[INSERT STATEMENT] (READ)

01 Not used

02 Turned on only a few days or nights when really needed

03 Turned on quite a bit

04 Turned on just about all summer

96 REFUSED

99 DON'T KNOW/NOT SURE

A35. Which of the following statements best describes the way your household used the most used window or wall air conditioning unit last summer? The most used window or wall airconditioner unit was [INSERT STATEMENT] (READ)

01 Not used

02 Turned on only a few days or nights when really needed

03 Turned on quite a bit

04 Turned on just about all summer

05 NO WORKING WINDOW/WALL UNITS IN HOME

96 REFUSED

99 DON'T KNOW/NOT SURE

A36. Which of the following statements best describes the way your household used a

Swamp or Evaporative Air Cooler last summer? It was [INSERT STATEMENT] (READ)

01 Not used

02 Turned on only a few days or nights when really needed

03 Turned on quite a bit

04 Turned on just about all summer

05 NO SWAMP/EVAPORATIVE AIR COOLER IN HOME.

96 REFUSED

99 DON'T KNOW/NOT SURE

A37. How many ceiling fans does your household have?

01 RESPONDENT GAVE NUMBER

Enter Number

02 None (SKIP to A38)

96 REFUSED

99 DON'T KNOW/NOT SURE

A37a. How many ceiling fans does your household use?

01 RESPONDENT GAVE NUMBER

Enter Number

02 None (SKIP to A38)

96 REFUSED (SKIP TO A38)

99 DON'T KNOW/NOT SURE (SKIP TO A38)

A37b. Thinking about the ceiling fan that you use the most, how often was this fan used last summer? Was it ... (READ)

01 Not used at all

02 Used only a few days or nights, when it's really needed

03 Used quite a bit

04 Used just about all summer

96 REFUSED 


\section{DON'T KNOW/NOT SURE}

A37c. Thinking about the ceiling fan that you use the most, how often was this fan used last winter? Was it ... (READ)

01 Not used at all

02 Used only a few days or nights

03 Used quite a bit

04 Used just about all winter

96 REFUSED

99 DON'T KNOW/NOT SURE

A38. Opening windows on opposite sides of the house to cool the indoor temperature is called natural cross ventilation. In the past 12 months, has your household used window fans to assist with natural cross ventilation in the warmer months?
01 Yes
02 No
96 REFUSED
99 DON'T KNOW/NOT SURE

A39. How often are your windows open in the summer? (READ)

01 Never

02 Rarely

03 Sometimes

04 Frequently

05 All the time

96 REFUSED

99 DON'T KNOW/NOT SURE

A40. How often are your windows open in the winter? (READ)

01 Never

02 Rarely

03 Sometimes

04 Frequently

05 All the time

96 REFUSED

99 DON'T KNOW/NOT SURE

A41. Do any large trees shade your home from the afternoon summer sun?

01 Yes

02 No

96 REFUSED

99 DON'T KNOW/NOT SURE

A42. Do you close the drapes, curtains, shades, and/or blinds during the day to block out the sun during the summer? (READ)

01 Never

02 Rarely

03 Sometimes

04 Frequently

05 All the time 
99 DON'T KNOW/NOT SURE

Now I have some questions on the indoor air temperature of your home.

A43. Does your home have a thermostat that controls the heating and/or cooling in your home?

01 Yes

02 No (SKIP to A62)

96 REFUSED (SKIP TO A62)

99 DON'T KNOW/NOT SURE (SKIP TO A62)

A43a. What equipment does your thermostat control? (READ)

01 Central heating only

02 Central cooling only

03 Central heating and cooling

96 REFUSED

99 DON'T KNOW

A44. Some thermostats can be programmed so that the temperature changes automatically at different times of the day; for example, the heat can be automatically turned down or lowered at night when you go to bed, then automatically adjusted up again in the morning. Is the thermostat that controls your main [INSERT ANSWER FROM A43a] equipment programmable?

01 Yes

02 No (SKIP to A55)

96 REFUSED (SKIP TO A55)

99 DON'T KNOW/NOT SURE (SKIP TO A55)

A45. Do you or someone else in your household know how to use the programmable thermostat?

01 Yes

02 No (SKIP to A55)

03 NO, SOMEONE WHO DOES NOT LIVE IN MY HOME PROGRAMS THE THERMOSTAT FOR USE (SKIP TO A55)

96 REFUSED (SKIP TO A55)

99 DON'T KNOW/NOT SURE (SKIP TO A55)

A46. Is your thermostat programmed to change the temperature at different times of the day?

01 Yes

02 No (SKIP to A48)

96 REFUSED (SKIP TO A48)

99 DON'T KNOW/NOT SURE (SKIP TO A48)

A47. I'm going to read you a list of statements, for each one please tell me if your programmable thermostat is used in this way or not.

a. Thermostat is automatically adjusted to a lower temperature at night during the winter

b. Thermostat is automatically adjusted to a lower temperature during the day when no one is home during the winter

c. Thermostat is automatically adjusted to a higher temperature at night during the summer

d. Thermostat is automatically adjusted to a higher temperature during the day when no one is home during the summer

01 Yes

02 No

96 REFUSED 


\section{DON'T KNOW/NOT SURE}

A48. How easy or difficult is it to use your programmable thermostat - very easy, somewhat easy, neither easy nor difficult, somewhat difficult or very difficult?

01 It is very easy to use

02 It is somewhat easy to use

03 It is neither easy nor difficult to use

04 It is somewhat difficult to use

05 It is very difficult to use

96 REFUSED

99 DON'T KNOW/NOT SURE

A49. Typically, how often is your programmable thermostat reprogrammed, that is, the time schedule and desired indoor temperature setting changed until it is reprogrammed again? (READ)

01 Daily

02 Weekly

03 Monthly

04 Every three months or so

05 Once a year

06 Less than once a year

07 Never

96 REFUSED

99 DON'T KNOW/NOT SURE

03

A50. How often is the current temperature setting "overridden" temporarily? (READ)

01 Daily

02 Weekly

03 Monthly

04 Every three months or so

05 Once a year

06 Less than once a year

07 Never

96 REFUSED

99 DON'T KNOW/REFUSED

IF A50=01, 02, 03, 04, 05, OR 06:

A50a. Please explain why the current temperature setting is "overridden" temporarily.

96 REFUSED

99 DON'T KNOW/NOT SURE

A51. How often is the "hold" mode used? (READ)

01 Daily

02 Weekly

03 Monthly

04 Every three months or so

05 Once a year

06 Less than once a year

07 Never

96 REFUSED

99 DON'T KNOW/NOT SURE 
IF A51=01, 02, 03, 04, 05 OR 06:

A51a. Please explain why the "hold" mode is used.

96 REFUSED

99 DON'T KNOW/NOT SURE

A52. Please indicate what features, if any, need improvement in your programmable thermostat. (READ.

SELECT ALL THAT APPLY.)

01 Size of words and numbers

02 Ease of programming

03 Additional features, such as the energy use in your home

04 Being able to change its settings using a cell phone, Internet

05 NO FEATURES NEED IMPROVEMENT

97 OTHER FEATURES. PLEASE SPECIFY.

96 REFUSED

99 DON'T KNOW/NOT SURE

A53. Is there anyone in your home who doesn't operate the programmable thermostat?

01 Yes

$02 \mathrm{No}$

96 REFUSED

99 DON'T KNOW/NOT SURE

IF A53=01:

A53a. Why is it that one or more household members do not operate the programmable thermostat?

(CODE ALL THAT APPLY) (READ)

01 It's too complicated/too difficult

02 You do not have an instruction manual or nobody showed you how

03 You haven't needed to

97 OTHER (SPECIFY)

96 REFUSED

99 DON'T KNOW/NOT SURE

A54. \{IF NO TO A46\} Why is your programmable thermostat not programmed to automatically change the temperature? (select all that apply) READ

01 You change the temperature manually or don't need to program

02 It takes too much effort to use

03 Household members cannot agree on what temperatures at which to set the thermostat

04 It is better to always keep the temperature setting always the same.

05 There is always somebody at home

97 OTHER (SPECIFY)

96 REFUSED

99 DON'T KNOW/NOT SURE

IF A54=04

A54a. Please explain why it's better to always keep the temperature setting always the same.

96 REFUSED

99 DON'T KNOW/NOT SURE

ASK A55-A57 IF A43a=01 OR A43a=03

A55. During the winter, at what temperature is the thermostat set when someone is inside your home during the day? [IF NO ANSWER, PROBE: CAN I JUST HAVE YOUR BEST ESTIMATE?] 
01 RESPONDENT GAVE TEMPERATURE

Enter degrees Fahrenheit

02 THERMOSTAT TURNED OFF (IF VOLUNTEERED)

96 REFUSED

99 DON'T KNOW/NOT SURE

A56. During the winter, at what temperature is the thermostat set when no one is inside your home during the day? [IF NO ANSWER, PROBE CAN I JUST HAVE YOUR BEST ESTIMATE?]

01 RESPONDENT GAVE TEMPERATURE

Enter degrees Fahrenheit

02 THERMOSTAT TURNED OFF (IF VOLUNTEERED)

96 REFUSED

99 DON'T KNOW/NOT SURE

A57. During the winter, at what temperature is the thermostat set inside your home at night? [IF NO

ANSWER, PROBE CAN I JUST HAVE YOUR BEST ESTIMATE?]

01 RESPONDENT GAVE TEMPERATURE

Enter degrees Fahrenheit

02 THERMOSTAT TURNED OFF (IF VOLUNTEERED)

96 REFUSED

99 DON'T KNOW/NOT SURE

\section{[ASK QUESTIONS A58, A59, A60 IF A43a=02 OR A43a=03]}

Now I would like you to think about the temperature inside your home when using your central air conditioning equipment last summer. For the next questions, if the thermostats are set at different temperatures, only report for the thermostat that affects the rooms where most of the people are.

A58. During the summer, at what temperature is the central air conditioning equipment set when someone is inside your home during the day? IF NO ANSWER, PROBE: WHAT'S YOUR BEST ESTIMATE?

01 RESPONDENT GAVE TEMPERATURE

Enter degrees Fahrenheit

02 Air-conditioner Turned Off

96 REFUSED

99 DON'T KNOW/NOT SURE

A59. During the summer, at what temperature is the central air conditioning equipment set when no one is inside your home during the day? IF NO ANSWER, PROBE: WHAT'S YOUR BEST ESTIMATE?

01 RESPONDENT GAVE TEMPERATURE

02 Air-conditioner Turned Off

Enter degrees Fahrenheit

96 REFUSED

99 DON'T KNOW/NOT SURE 
A60. During the summer, at what temperature is the central air conditioning equipment set inside your home at night? IF NO ANSWER, PROBE: WHAT'S YOUR BEST ESTIMATE?

01 RESPONDENT GAVE TEMPERATURE

02 Air-conditioner Turned Off

Enter degrees Fahrenheit

96 REFUSED

99 DON'T KNOW/NOT SURE

Now I'm going to read you a set of statements about heating and cooling. For each one, please tell me if the statement is true or false.

A61a. If the thermostat is turned up very high in the winter, my home will get warmer faster.

01 True

02 False

96 REFUSED

99 DON'T KNOW/NOT SURE

A61b. The thermostat controls the temperature of the air coming from the heating/cooling unit into my home.
01 True
02 False
96 REFUSED
99 DON'T KNOW/NOT SURE

A61c. The thermostat only senses the temperature in the air in the room where the thermostat is located. It turns the heating unit off when the temperature in the room reaches the temperature on the thermostat setting.
01 True
02 False
96 REFUSED
99 DON'T KNOW/NOT SURE

A61d. If the thermostat is turned down at night or when no one is home, then more energy is used than saved when your home is heated up again.

01 True

02 False

96 REFUSED

99 DON'T KNOW/NOT SURE

A62. In the past 12 months, was your household unable to use any of the following equipment because it was broken? [READ LIST CHECK ALL THAT APPLY\}

01 Main Heating Equipment

02 Central Air Conditioner

03 Room Air Conditioner

04 NO EQUIPMENT BROKEN

96 REFUSED

99 DON'T KNOW/NOT SURE

A63. Please think about the indoor temperature of your home during the winter. Is it typically, [READ LIST]

01 Very cold

02 Cold 
03 Comfortable

04 Hot

05 Very hot

97 OTHER

96 REFUSED

99 DON'T KNOW/NOT SURE

A64. Please think about the indoor temperature of your home during the summer. Is it typically, [READ LIST]

01 Very cold

02 Cold

03 Comfortable

04 Hot

05 Very hot

97 OTHER

96 REFUSED

99 DON'T KNOW/NOT SURE

A65. In the past 12 months, has a landlord controlled the temperature inside your home?

01 Yes

02 No

03 DO NOT HAVE LANDLORD (IF VOLUNTEERED)

96 REFUSED

99 DON'T KNOW/NOT SURE

A66. In the past 12 months how often did your household keep your home at a temperature that you felt was unsafe or unhealthy? [READ]

01 Almost every month

02 Some months

031 or 2 months

04 Never

96 REFUSED

99 DON'T KNOW/NOT SURE

A67. In the past 12 months, has anyone in the household needed medical attention because your home was too cold?
01 Yes
02 No
96 REFUSED
99 DON'T KNOW/NOT SURE

A68. In the past 12 months did anyone in your household need medical attention because your home was too hot?
01 Yes
02 No
96 REFUSED
99 DON'T KNOW 
A69. During the past 12 months, how often have you or other members of your household found your home too drafty? Would you say. . . (READ)

01 All the time

02 Most of the time

03 Some of the time

04 Never

96 REFUSED

99 DON'T KNOW/NOT SURE

\section{B. OCCUPANT BEHAVIOR IN HOME}

The next group of questions is about laundry appliances and water use in your home.

B1. Is a clothes washing machine used in your home? (READ IF NECESSARY: Do not include community clothes washers that are located in the basement or laundry room of your apartment building.)

01 Yes

02 No (SKIP to B2)

96 REFUSED (SKIP TO B2)

99 DON'T KNOW/NOT SURE (SKIP TO B2)

B1a. In an average week, how many loads of laundry are washed in your clothes washer? (READ)

011 load or less

022 to 4 loads

035 to 9 loads

0410 to 15 loads

05 More than 15 loads

96 REFUSED

99 DON'T KNOW/NOT SURE

B1b. How often does your household wash only full loads of laundry? (READ)

01 Always

02 Most of the time

03 Some of the time

04 Never

96 REFUSED

99 DON'T KNOW/NOT SURE

B1c. What water temperature setting is usually used for the wash cycle of your clothes washer? Is it hot, warm, or cold water?

01 Hot

02 Warm

03 Cold

96 REFUSED

99 DON'T KNOW/NOT SURE

B1d. What water temperature setting is usually used for the rinse cycle of your clothes washer? Is it hot, warm, or cold water?

01 Hot

02 Warm

03 Cold

96 REFUSED 


\section{DON'T KNOW/NOT SURE}

B2. Do you use a clothes dryer in your home? (READ IF NECESSARY: Do not include community clothes dryers that are located in the basement or laundry room of your apartment building.)

01 Yes

02 No (SKIP TO B3)

96 REFUSED (SKIP TO B3)

99 DON'T KNOW/NOT SURE (SKIP TO B3)

B2a. How often does your household dry only full loads of laundry....? (READ)

01 Always

02 Most of the time

03 Some of the time

04 Never

96 REFUSED

99 DON'T KNOW/NOT SURE

B2b. Does your clothes dryer vent directly to the outdoors?

01 Yes

02 No

03 DRYER IS VENTLESS (IF VOLUNTEERED)

96 REFUSED

99 DON'T KNOW/NOT SURE

B2c. Do you clean your clothes dryer's lint filter after every use?

01 Yes

02 No

03 DRYER HAS NO LINT FILTER (IF VOLUNTEERED)

96 REFUSED

99 DON'T KNOW/NOT SURE

B3. How frequently does your household hang clothes to dry? (READ)

01 Very frequently

02 Frequently

03 Infrequently

04 Very infrequently

05 Never

96 REFUSED

99 DON'T KNOW/NOT SURE

B4. In the last 12 months, has the temperature of your hot water heater been adjusted?

01 Yes

02 No

03 NO WATER HEATER (IF VOLUNTEERED)

96 REFUSED

99 DON'T KNOW/NOT SURE

IF B4=01:

B4a. How has the temperature been adjusted? (READ)

01 The temperature is much warmer

02 The temperature is warmer 
03 The temperature is cooler

04 The temperature is much cooler

05 Hot water heater was not in working order for the last 12 months

96 REFUSED

99 DON'T KNOW/NOT SURE

B5. Over the past 12 months, has the duration of the showers taken by household members increased, decreased, or not changed?

01 Increased

02 Decreased

03 Not changed

04 NO SHOWER (IF VOLUNTEERED)

96 REFUSED

99 DON'T KNOW/NOT SURE

IF B5=01 OR B5=02

B5a. Has the duration of showers taken by household members (IF B5=01: increased; IF B5=02: decreased) a lot or some?

01 A lot

02 Some

96 REFUSED

99 DON'T KNOW/NOT SURE

B6. Does your main bathroom have a ventilation fan in it that works?

01 Yes

02 No (SKIP to B7)

96 REFUSED (SKIP TO B7)

99 DON'T KNOW (SKIP TO B7)

B6a. How often do you or members of your household operate the fan while showering? (READ)

01 Never

02 Rarely

03 Sometimes

04 Frequently

05 All the time

96 REFUSED

99 DON'T KNOW/NOT SURE

SKIP if B6a $=01,96,99$

B6b. How long after showering do you or members of your household operate the fan? (READ)

01 The fan is turned off when leaving the shower area

02 A few minutes

03 Several minutes

04 Until the steam in the shower area is gone

96 REFUSED

99 DON'T KNOW/NOT SURE

B7. Electric dehumidifiers remove moisture from the air and are often used in the summer. Is a dehumidifier used in your home?

01 Yes

02 No (SKIP to B8) 
96 REFUSED (SKIP TO B8)

99 DON'T KNOW/NOT SURE (SKIP TO B8)

B7a. In the past 12 months, how many months was the dehumidifier used? (READ)

011 to 3 months

024 to 6 months

037 to 9 months

0410 to 11 months, but not all year

05 Turned on all year long

96 REFUSED

99 DON'T KNOW/NOT SURE

Now I have some questions about lights and appliances inside your home.

B8. How often do you find lights left on in rooms that are not occupied? (READ)

01 Never

02 Almost never

03 Sometimes

04 Most of the time

05 All the time

96 REFUSED

99 DON'T KNOW/NOT SURE

B9. Do members of your household purchase or intentionally seek out and install compact fluorescent bulbs in your home?

01 Yes

02 No (SKIP to B10)

03 I DO NOT KNOW WHAT COMPACT FLUORESCENT BULBS ARE (IF VOLUNTEERED) (SKIP to B10)

96 REFUSED (SKIP TO B10)

99 DON'T KNOW/NOT SURE (SKIP TO B10)

B9a. How do you dispose of compact fluorescent light bulbs that are broken or no longer working? Are they (READ)

01 Put directly in household garbage

02 Doubled bagged in plastic in household garbage

03 Transported to local recycling center

97 OTHER (PLEASE SPECIFY)

96 REFUSED

99 DON'T KNOW/NOT SURE

B10. Are you familiar with the Energy Star ${ }^{\circledR}$ label?

01 Yes

02 No (SKIP to B11)

96 REFUSED (SKIP TO B11)

99 DON'T KNOW/NOT SURE (SKIP TO B11) 
B10a. Has your household bought or intentionally installed appliances or consumer electronics that have an Energy Star® label?

01 Yes

02 No

96 REFUSED

99 DON'T KNOW/NOT SURE

B11. Do you unplug any appliances like TVs, VCRs, stereos, radios, clocks, or computers when they are turned off?

01 Yes

02 No

96 REFUSED

99 DON'T KNOW/NOT SURE

\section{HOME CONDITIONS}

In this next set of questions, I will ask you about other conditions of your home.

C1. Do you rent or own your current residence?

01 Rent

02 Own

97 OTHER (IF VOLUNTEERED) (Please describe the housing agreement).

96 REFUSED

99 DON'T KNOW/NOT SURE

C2. How much outdoor noise do you hear indoors when the windows are closed? (READ)

01 A great deal

02 Some

03 Hardly any

04 None at all

96 REFUSED

99 DON'T KNOW/NOT SURE

C3. Please rate the outside appearance of your home: (READ)

01 Very attractive

02 Attractive

03 Neither attractive nor unattractive

04 Unattractive

05 Very unattractive

96 REFUSED

99 DON'T KNOW/NOT SURE

SKIP IF C1=01:

C4. Over the past 12 months, has the property value of your home changed?

01 Yes

02 No

96 REFUSED

99 DON'T KNOW/NOT SURE 
IF C4=01:

C4a. How has the property value of your home changed. Would you said it is [INSERT STATEMENT] (READ):

01 Very much higher

02 Higher

03 Lower

04 Very much lower

96 REFUSED

99 DON'T KNOW/NOT SURE

C5. How infested is your home with cockroaches or other insects or spiders? (READ)

01 Extremely infested

02 Very infested

03 Somewhat infested

04 Hardly infested

05 Not infested at all (SKIP to C6)

96 REFUSED (SKIP TO C6)

99 DON'T KNOW/NOT SURE (SKIP TO C6)

C5a. What have you done about the cockroaches, other insects or spiders? (READ) CHECK ALL THAT APPLY

01 Nothing

02 Used insecticides, bug sprays, or poison

03 Hired an exterminator or other professional

97 OTHER. PLEASE SPECIFY.

96 REFUSED

99 DON'T KNOW/NOT SURE

C6. How infested is your home with rats or mice? (READ)

01 Extremely infested

02 Very infested

03 Somewhat infested

04 Hardly infested

05 Not infested at all (SKIP to C7)

96 REFUSED (SKIP TO C7)

99 DON'T KNOW/NOT SURE (SKIP TO C7)

C6a. What have you done about the pests? (READ) CHECK ALL THAT APPLY

01 Nothing

02 Used bait or poison

03 Hired an exterminator or other professional

97 OTHER. PLEASE SPECIFY.

96 REFUSED

99 DON'T KNOW/NOT SURE

C7. Does your home frequently have a mildew odor or musty smell?

01 Yes

02 No

96 REFUSED

99 DON'T KNOW/NOT SURE 
C8. How often do you observe standing water anywhere in your home? Examples of standing water include wet carpet, puddles, or flooding in the home. (READ)
01 Never
02 Rarely
03 Sometimes
04 Often
05 Always
96 REFUSED
99 DON'T KNOW/NOT SURE

C9. Have you seen mold in your home in the past 12 months?

01 Yes

02 No \{SKIP to D1\}

96 REFUSED (SKIP TO D1)

99 DON'T KNOW/NOT SURE (SKIP TO D1)

C9a. $\{$ If C9=01 $\}$ What have you done about the mold? (READ) CHECK ALL THAT APPLY

01 Nothing

02 Cleaned with bleach

03 Cleaned with other chemical mold remover

04 Cleaned with natural mold remover (vinegar or natural product)

05 Air Conditioned

06 Ventilation (fans)

07 Used a dehumidifier

08 Contacted a Professional

97 OTHER. PLEASE SPECIFY

96 REFUSED

99 DON'T KNOW/NOT SURE

\section{ENERGY BILLS}

Now I would like to ask you a few questions about your energy bills.

Some households may have faced challenges in paying home energy bills. The following questions ask about challenges your household may have had paying home energy bills or maintaining heating and cooling equipment. When thinking about these questions, include all of your experiences in the past 12 months.

D1. Some energy utilities and suppliers offer budget payment plans that allow a household to pay the same amount on the home energy bill each month. In the past 12 months, did your household use a budget plan for any home energy bill?
01 Yes
02 No
96 REFUSED
99 DON'T KNOW/NOT SURE

D2. How well do you understand the information on your energy bill other than the amount owed? For example, information about how much energy your household used during the billing period compared to the same billing period one year ago. (READ) 
01 Very well

02 Well

03 Neither well nor not well

04 Not well

05 Not well at all

96 REFUSED

99 DON'T KNOW/NOT SURE

D3. How hard is it to pay your energy bills? (READ)

01 Very hard

02 Hard

03 Neither hard or not hard

04 Not hard

05 Not hard at all

96 REFUSED

99 DON'T KNOW

D4. Has your household had to move in the past 5 years because your household could not pay the energy bills?
01 Yes
02 No
96 REFUSED
99 DON'T KNOW/NOT SURE

D5. Over the past 12 months, how often has your household not paid energy bills in order to pay other utility bills? Other utilities includes water/sewage/telephone/Secondary energy fuel (READ)
01 Every month
02 Every other month
03 Every few months
04 Every six months
05 Once in twelve months
06 Never
96 REFUSED
99 DON'T KNOW/ NOT SURE

D6. Over the past 12 months, how often has your household not paid other utilities in order to pay the primary energy bill? [IF NECESSARY: by other utilities, I mean water/sewage/telephone/Secondary energy fuel. ] (READ)

01 Every month

02 Every other month

03 Every few months

04 Every six months

05 Once in twelve months

06 Never (SKIP to D7)

96 REFUSED (SKIP TO D7)

99 DON'T KNOW/NOT SURE (SKIP TO D7)

D6a. What utilities were not paid for in order to pay an energy bill? (READ) CHECK ALL THAT APPLY.

01 Water

02 Sewage 
03 Telephone

04 Secondary energy fuel type

97 OTHER (SPECIFY

96 REFUSED

99 DON'T KNOW/NOT SURE

D7. Over the past 12 months, how often has your household not purchased food in order to pay an energy bill? (READ)

01 Every month

02 Every other month

03 Every few months

04 Every six months

05 Once in twelve months

06 Never

96 REFUSED

99 DON'T KNOW/NOT SURE

D8. Over the past 12 months, how often has your household not paid energy bills in order to purchase food? (READ)

01 Every month

02 Every other month

03 Every few months

04 Every six months

05 Once in twelve months

06 Never

96 REFUSED

99 DON'T KNOW/NOT SURE

D9. In the past four weeks, did you or any household member go a whole day and night without eating anything because there was not enough food?

01 Yes

02 No

96 REFUSED

99 DON'T KNOW/NOT SURE

D10. In the past four weeks, did you worry that your household members would not have nutritious food?

01 Yes

02 No

96 REFUSED

99 DON'T KNOW/NOT SURE

D11. Some households receive additional assistance to help pay for food. In the past 12 months did you or any members of your household receive food stamps or WIC assistance (Women, Infants, and Children nutrition program)? (ASK ONCE/DO NOT REPEAT QUESTION FOR EACH INDIVIDUAL)

01 Yes

02 No

96 REFUSED

99 DON'T KNOW/NOT SURE 
IF D1 $1=02$

D11a. Did you not receive those benefits because you did not apply or because you applied but were rejected?

01 Did not apply

02 Applied for, but rejected

96 REFUSED

99 DON' KNOW/NOT SURE

D12. In the past 5 years have you or anyone in the household experienced any of the following as a result of energy bills? (READ. CHECK ALL THAT APPLY.)

01 Eviction from home

02 Foreclosure on mortgage

03 Moved in with friends or family

04 Moved into a shelter or been homeless

05 Family Separation

06 NONE (DO NOT READ)

96 REFUSED

99 DON'T KNOW/NOT SURE

D12a. $\{$ If D12=05 $\}$ In what way or ways was the family separated? (READ. SELECT ALL THAT APPLY.)

01 Adult partners only separated

02 One adult partner separated from partner and children

03 One parent separated from children only

04 Both parents separated from children

05 Elder parent or relative separated from family

96 REFUSED

99 DON'T KNOW/NOT SURE

D13. In the past 12 months how often did your household pay an amount less than what you owed on your home energy bill, because you were unable to afford the whole home energy bill? (READ)

01 Almost every month

02 Some months

031 or 2 months

04 Never

96 REFUSED

99 DON'T KNOW/NOT SURE

D14. In the past year, have you used any of the following to assist with paying your energy bill? First [INSERT ITEM] [IF NECESSARY: In the past year, have you used a [INSERT] to assist with paying your energy bill?]

a. Payday loan

b. Tax Refund Anticipation Loan

c. Car Title Loan

d. Other type of short term, high-interest loan

e. Pawn shop

01 Yes

02 No

96 REFUSED

99 DON'T KNOW/NOT SURE 
D14a_01 - D14e_01. \{FOR EVERY 01 FOR D14a through D14e $\}$ In the past year, in order to pay your home energy bill, how often did you need to use a (INSERT ANSWER IN D14a-D14e) (READ)

01 Almost every month

02 Some months

031 or 2 months

04 Never

96 REFUSED

99 DON'T KNOW/NOT SURE

D15. When home energy bills are not paid on time, it is common for energy utilities and suppliers to send late notices. If the bill is very late, they will send a disconnect, shut-off, or non-delivery notice. In the past 12 months, how often did you receive a disconnect, shut-off, or non-delivery notice? (READ)

01 Almost every month

02 Some months

031 or 2 months

04 Never (SKIP to D17)

96 REFUSED (SKIP TO D17)

99 DON'T KNOW/NOT SURE (SKIP TO D17)

D15a. Did you enter into a payment arrangement with your energy utility or supplier in response to the disconnect shut-off, or non-delivery notice?

01 Yes

02 No

96 REFUSED

99 DON'T KNOW/NOT SURE

D16. In the past 12 months was your electricity or natural gas ever disconnected because you were unable to pay your home energy bill?

01 Yes

02 No (SKIP to D17)

96 REFUSED (SKIP TO D17)

99 DON'T KNOW/NOT SURE (SKIP TO D17)

D16a. While your electricity or natural gas was disconnected, was there a time when you wanted to use your main source of heat but were unable to?

01 Yes

02 No

96 REFUSED

99 DON'T KNOW/NOT SURE

D16b. While your electricity was disconnected, was there a time when you wanted to use your air conditioner but were unable to?

01 Yes

02 No

96 REFUSED

99 DON'T KNOW/NOT SURE 
D17. In the past 12 months did your fuel oil, kerosene, propane, or wood ever run out because you were unable to pay for a home energy delivery?

01 Yes

02 No (SKIP to SECTION E)

96 REFUSED (SKIP TO SECTION E)

99 DON'T KNOW/NOT SURE (SKIP TO SECTION E)

D17a. When you ran out of your fuel oil, kerosene, propane, or wood was there a time when you wanted to use your main source of heat but were unable to?

01 Yes

02 No

96 REFUSED

99 DON'T KNOW/NOT SURE

\section{E. HEALTH CARE AND COVERAGE}

Next, I will be asking about health care and coverage.

E1. In the past 12 months have you had any kind of health care coverage, including health insurance, prepaid plans such as HMOs, or government plans such as Medicare?

01 Yes (SKIP to E1b)

02 No

96 REFUSED

99 DON'T KNOW/NOT SURE

E1a. $\{$ IF E1=02, 96, 99 $\}$, Just to be sure I understand your answer, you do NOT have health care coverage of any kind, is that correct? Do you have health insurance or coverage through a plan I might have missed? (INTERVIEWER: REVIEW PLANS IF INFORMANT IS UNSURE. SELECT ALL

THAT APPLY.)

01 NO/NOT COVERED BY ANY PLAN (SKIP to E2)

02 HEALTH INSURANCE PLAN FROM A CURRENT OR PAST EMPLOYER/UNION/SCHOOL

03 A HEALTH INSURANCE PLAN BOUGHT ON HIS/HER OWN/PROF. ASSN

04 A PLAN BOUGHT BY SOMEONE WHO DOES NOT LIVE IN THIS HOUSEHOLD

05 MEDICARE

06 MEDICAID/STATE NAME

07 CHAMPUS/CHAMP-VA, TRICARE, VA,

08 OTHER MILITARY

09 INDIAN HEALTH SERVICE

10 [fill STATE PLAN]

97 OTHER PLAN [SPECIFY]

96 REFUSED

99 DON'T KNOW/NOT SURE

E1b. $\{$ ASK IF E1=01 OR E1a $\neq 01\}$ During the past 12 months was there any time that you did not have any health insurance coverage?

01 Yes

02 No

96 REFUSED

99 DON'T KNOW/NOT SURE 
E1c. Does your health plan pay for at least some of the cost of prescription medicines prescribed by a doctor?
01 Yes
02 No
96 REFUSED
99 DON'T KNOW

E2. During the past 12 months, was there any time your household members needed prescription medicines but didn't get them because you couldn't afford it?
01 Yes
02 No
96 REFUSED
99 DON'T KNOW/NOT SURE

E3. Over the past 12 months, how often did members of your household not fill a prescription or take less than the full dose of a prescribed medicine in order to pay the utility bill? (READ)
01 Every month
02 Every other month
03 Every few months
04 Every six months
05 Once in twelve months
06 Never
96 REFUSED
99 DON'T KNOW/NOT SURE

E4. Over the past 12 months, how frequently has your household not paid energy bills in order to purchase prescription medicines? (READ)

01 Every month

02 Every other month

03 Every few months

04 Every six months

05 Once in twelve months

06 Never

96 REFUSED

99 DON'T KNOW/NOT SURE

E5. Was there a time in the past 12 months when you needed to see a doctor but could not because of cost?

01 Yes

02 No

96 REFUSED

99 DON'T KNOW/NOT SURE

E6. During the past 12 months, have you or other adults in your household had any problems paying medical bills?

01 Yes

02 No

96 REFUSED

99 DON'T KNOW/NOT SURE 
E7. Including yourself, how many people normally live in this household? Do not include anyone who is just visiting, those away in the military, or children who are away at college.

\author{
Enter Number \\ 96 REFUSED (SKIP TO E9) \\ 98 DON'T KNOW/NOT SURE (SKIP TO E9)
}

E8. Now, I'd like to get some information about each member of the household so I can ask questions about each. Could you please give me the name, gender, age and whether or not they are in school for each person in the household. First, let's start with you --

[IF E7=1]: Can you tell me your name again, as well as your age and whether or not you are in school. [IF E7>11: Now let's turn to the next person in the household. Can you please tell me that person's first name, gender and age, and that person's relationship to you. (INTERVIEWER NOTE: "so that person is your ")

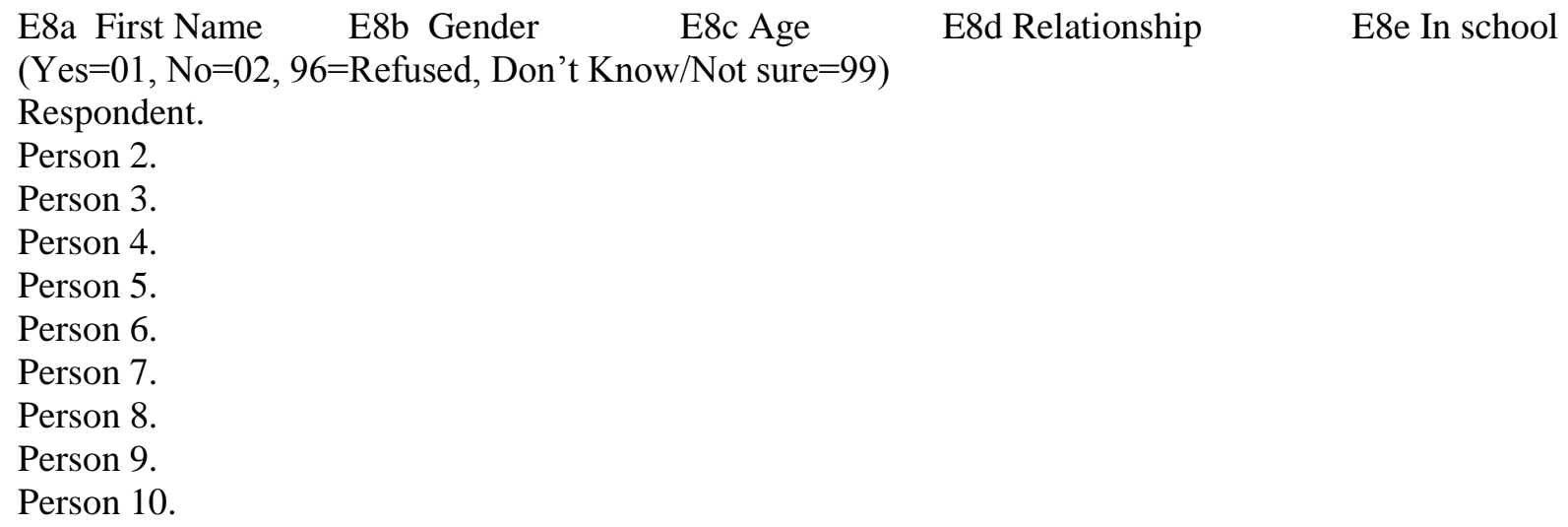

E9. On a typical week day is there someone at home most or all of the day?
01 Yes
02 No
96 REFUSED
99 DON'T KNOW/NOT SURE

For this section, I will be asking health related questions.

E10. Now thinking about physical health, which includes physical illness and injury, for how many days during the past 30 days was your physical health not good?

01 Number of days

02 None

96 REFUSED

99 DON'T KNOW/NOT SURE

E11. Now thinking about your mental health, which includes stress, depression, and problems with emotions, for how many days during the past 30 days was your mental health not good?

01 Number of days

02 None

96 REFUSED

99 DON'T KNOW/NOT SURE 
E12. During the past 30 days, for about how many days have you felt you did not get enough rest or sleep?

01 Number of days

02 None

96 REFUSED

99 DON'T KNOW/NOT SURE

E13. During the past 30 days, for about how many days have you felt very healthy and full of energy?

01 Number of days

02 None

96 REFUSED

99 DON'T KNOW/NOT SURE

E14. During the past 30 days, for about how many days did poor physical or mental health keep you from doing your usual activities, such as self-care, work, or recreation?

01 Number of days

02 None

96 REFUSED

99 DON'T KNOW/NOT SURE

Next, I am going to ask you whether you have had some particular health problems in the last 3 months. In the past 3 months, have you had ...

E15. Shortness of breath when lying down, waking up, or with light work or light exercise?
01 Yes
02 No
96 REFUSED
99 DON'T KNOW/NOT SURE

E16. Headaches that are either new or more frequent or severe than ones you have had before?

01 Yes

02 No

96 REFUSED

99 DON'T KNOW/NOT SURE

In the past 12 months were you or anyone else in the household ever told by a doctor or health professional that you or they have.. [READ EACH ITEM AND GET YES/NO. FOR E17-E24, READ IF NECESSARY: "In the past 12 months were you or anyone in your household told by a doctor or health professional that you or they have...."

E17. Lead poisoning

01 Yes

02 No

96 REFUSED

99 DON'T KNOW/NOT SURE

$\{$ IF E17=01 $\}$ Please list all individuals, including yourself: 
E18. Three or more ear infections per year

01 Yes

02 No

96 REFUSED

99 DON'T KNOW/NOT SURE

$\{$ IF E18=01 $\}$ Please list all individuals, including yourself:

E19. Any kind of respiratory allergy

01 Yes

02 No

96 REFUSED

99 DON'T KNOW/NOT SURE

$\{$ IF E19=01 $\}$ Please list all individuals, including yourself:

E20. Flu

01 Yes

02 No

96 REFUSED

99 DON'T KNOW/NOT SURE

$\{$ IF E20 $=01\}$ Please list all individuals, including yourself:

E21. Persistent Cold symptoms lasting more than 14 days READ: Symptoms include coughing, sore throat, sneezing, sinus pain, congestion, fever, fatigue, and headache.

01 Yes

02 No

96 REFUSED

99 DON'T KNOW/NOT SURE

$\{$ IF E21=01 $\}$ Please list all individuals, including yourself:

E22. Sinus infection or Sinusitis

01 Yes

02 No

96 REFUSED

99 DON'T KNOW/NOT SURE

$\{$ IF E22=01 $\}$ Please list all individuals, including yourself: 
E23. Bronchitis

01 Yes

02 No

96 REFUSED

99 DON'T KNOW/NOT SURE

$\{$ IF E23=01 $\}$ Please list all individuals, including yourself:

E24. Have you ever been told by a doctor or other health professional that you have asthma?

01 Yes

02 No (SKIP to E25)

96 REFUSED (SKIP TO E25)

99 DON'T KNOW/NOT SURE (SKIP TO E25)

E24a. Do you still have asthma?

01 Yes

02 No

96 REFUSED

99 DON'T KNOW/NOT SURE

E24b. During the past 12 months, how many times did you see a doctor or health professional for a routine checkup for your asthma? READ: Symptoms of asthma include coughing, wheezing, shortness of breath, chest tightness or phlegm production when you have a cold or respiratory infection.

\section{RESPONDENT GAVE NUMBER ENTER NUMBER \\ 96 REFUSED \\ 99 DON' T KNOW/NOT SURE}

E24c. How long has it been since you last had any symptoms of asthma? (READ)

01 Never

02 Less than one day ago

03 1-6 Days ago

041 week to less than 3 months ago

053 months to less than 1 year ago

061 year to less than 3 years ago

073 years to 5 years ago

08 More than 5 years ago

96

REFUSED

99 DON'T KNOW/NOT SURE

E24d. During the past 12 months did you have to stay overnight in the hospital because of asthma?

01 Yes

02 No

96 REFUSED

99 DON'T KNOW/NOT SURE 
E24e. Not counting hospitalizations, during the past 12 months, did you go to an emergency room because of asthma?

01 Yes

02 No

96 REFUSED

99 DON'T KNOW/NOT SURE

These next questions are about cigarette smoking.

E25. Which one of the following statements best describes the rules about smoking in your home...(READ)

01 No one is allowed to smoke anywhere inside your home

02 Smoking is allowed at some places or at sometimes

03 Smoking is permitted anywhere

96 REFUSED

99 DON'T KNOW/NOT SURE

E26. Have you smoked at least 100 cigarettes in your entire life?

01 Yes

02 No

96 REFUSED

99 DON'T KNOW/NOT SURE

E27. Do you now smoke cigarettes every day, some days or not at all?

01 Everyday

02 Some days

03 Not at all

96 REFUSED

99 DON'T KNOW/NOT SURE

E28. In the past 12 months has anyone in the household been food poisoned from eating food inside your home and therefore went to see a medical professional?
01 Yes
02 No
96 REFUSED
99 DON'T KNOW/NOT SURE

E29. In the past 12 months, has anyone in the household been poisoned by breathing in carbon monoxide, and therefore went to see a medical professional?
01 Yes
02 No
96 REFUSED
99 DON'T KNOW/NOT SURE

E30. In the past 12 months, has anyone in the home been burned from scalding hot water coming out of a faucet or showerhead in your home?

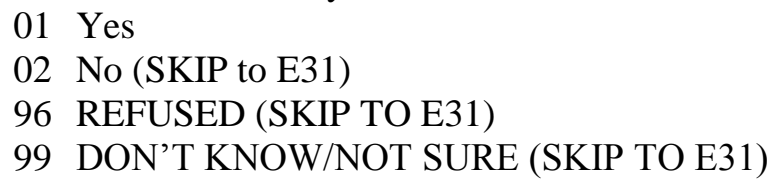


E30a. $\{$ IF E30=01 $\}$ Did you talk to or see a medical professional about this injury?

01 Yes

02 No

96 REFUSED

99 DON'T KNOW/NOT SURE

E31. I am going to read some statements about health and medical care. For each one, please tell me if it is definitely true, mostly true, mostly false or definitely false. First, usually, you go to the doctor as soon as you start to feel bad. Is that (READ):

01 definitely true

02 mostly true

03 mostly false

04 definitely false

96 REFUSED

99 DON'T KNOW/NOT SURE

E32. You will do just about anything to avoid going to the doctor. Is that ... (READ)

01 definitely true

02 mostly true

03 mostly false

04 definitely false

96 REFUSED

99 DON'T KNOW/NOT SURE

\section{F. EMPLOYMENT/SCHOOLING}

In this section I will be asking employment and school related questions.

[SKIP IF E7=1]

F1. Are you the primary wage earner in your household?

01 YES

$02 \mathrm{NO}$

03 NO PRIMARY WAGE EARNER IN THE HOUSEHOLD

96 REFUSED

99 DON'T KNOW/NOT SURE

F1a. [IF F1=01 OR F1=03 OR E7=1: Are you; IF F1=02 OR F1=96 OR F1=99: Is the primary wage earner in the household] currently...? (READ)

01 Employed for wages

02 Self-employed

03 Out of work for more than 1 year (SKIP toF1d)

04 Out of work for less than 1 year (SKIP toF1d)

05 A Homemaker (SKIP to F2)

06 A Student

07 Retired (SKIP to F2)

08 Unable to work (SKIP to F2)

96 REFUSED

99 DON'T KNOW/NOT SURE 
F1b. [IF F1=01 OR F1=03 OR E7=1: Are you; IF F1=02 OR F1=96 OR F1=99: Is the primary wage earner in the household] employed full-time or part-time?

01 Full-time

02 Part-time

96 REFUSED

99 DON'T KNOW/NOT SURE

F1c. How many hours per week [IF F1=01 OR F1=03 OR E7=1: do you; IF F1=02 OR F1=96 OR F1=99: does the primary wage earner in the household] usually work at all of [IF F1=01 OR F1=03 OR E7=1: your; IF F1=02 OR F1=96 OR F1=99: their] jobs?

01 RESPONDENT GAVE HOURS

Enter hrs

96 REFUSED

99 DON'T KNOW/NOT SURE

F1d. \{ IF ANSWERED (03) or (04) to F1a $\}$ [IF F1=01 OR F1=03 OR E7=1: Have you; IF F1=02 OR F1=96 OR F1=99: Has the primary wage earner in the household] looked for work during the last 4 weeks?
01 Yes
02 No
96 REFUSED
99 DON'T KNOW/NOT SURE

F1e. $\{$ IF ANSWERED 02 to F1d $\}$ What is the main reason [IF F1=01 OR F1=03 OR E7=1: you were; IF F1=02 OR F1=96 OR F1=99: the primary wage earner was] not looking for work during the LAST 4 WEEKS? CHECK ALL THAT APPLY (DO NOT READ LIST)
01 Believes no work available in line of work or area
02 Couldn't find any work
03 Lacks necessary schooling, training, skills or experience
04 Employers think too young or too old
05 Other types of discrimination
06 Can't arrange child care
07 Family responsibilities
08 In school or other training
09 Ill health, physical disability
10 Transportation problems
97 OTHER (SPECIFY
96 REFUSED
99 DON'T KNOW/NOT SURE

F2. Does a physical, mental or emotional problem NOW keep [IF F1=01 OR F1=03 OR E7=1: you; IF F1=02 OR F1=96 OR F1=99: the primary wage earner in the household] from working at a job or business?
01 Yes
02 No
96 REFUSED
99 DON'T KNOW/NOT SURE 
F3. In the past 12 months did anyone in the household receive income from any of the

following sources? (READ AND CHECK ALL THAT APPLY)

01 Supplemental Security Income (SSI)

02 Welfare payments or case assistance

03 Veteran's payments (VA Benefits)

04 Unemployment Compensation

05 NONE OF THESE SOURCES

96 REFUSED

99 DON'T KNOW/NOT SURE

F4. $\{$ IF ANSWERED (01), (02), (04), or (06) to F1a $\}$ During the past 12 months [IF F1=01 OR F1=03 OR E7=1: have you; IF F1=02 OR F1=96 OR F1=99: has the primary wage earner in the household] had more than one job (or business), including part time, evening, or weekend work?

01 Yes

02 No

96 REFUSED

99 DON'T KNOW/NOT SURE

F5. \{ IF ANSWERED (01), (02), (04), or (06) to F1a \}Thinking about the last 12 months, is [IF F1=01 OR F1=03 OR E7=1: your; IF F1=02 OR F1=96 OR F1=99: the primary wage earner's] main job, that is, where the most hours were worked, considered seasonal?

01 Yes

02 No (SKIP to F6)

96 REFUSED (SKIP TO F6)

99 DON'T KNOW/NOT SURE (SKIP TO F6)

F5a. In what season [IF F1=01 OR F1=03 OR E7=1: do you; IF F1=02 OR F1=96 OR F1=99: does the primary wage earner] work the least amount of hours?

01 Winter

02 Spring

03 Summer

04 Fall

96 REFUSED

99 DON'T KNOW/NOT SURE

F6. \{ IF ANSWERED (01) or (02) TO F1a $\}$ In the past 12 months, about how many days of work did [IF F1=01 OR F1=03 OR E7=1: you; IF F1=02 OR F1=96 OR F1=99: the primary wage earner] miss at a job or business because of illness or injury. READ: Do not include maternity leave.

01 RESPONDENT GAVE NUMBER

Enter Number

02 None

96 REFUSED

99 DON'T KNOW/NOT SURE 
[SKIP IF E7=1]

F7. \{IF ANSWERED (01) or (02) TO F1a \}In the past 12 months, about how many days of work did [IF F1=01 OR F1=03: you; IF F1=02 OR F1=96 OR F1=99: the primary wage earner] miss because of illness or injury of another household member?

01 RESPONDENT GAVE NUMBER

Enter Number

02 None

96 REFUSED

99 DON'T KNOW/NOT SURE

[ASK IF E8e=01 FOR RESPONDENT, SKIP IF E7=96/99]

F8. In the past 12 months, about how many days of school have you missed because of illness or injury?

01 RESPONDENT GAVE NUMBER

ENTER NUMBER

02 NONE

03 NOT IN SCHOOL

96 REFUSED

99 DON'T KNOW/NOT SURE

[SKIP IF E7=1]

[ASK IF $F 1=02$ or $F 1=96$ or $F 1=99]$

F8a. And, in the past 12 months, about how many days of school has the primary wage earner missed because of illness or injury?

01 RESPONDENT GAVE NUMBER
ENTER NUMBER_-
02 NONE
03 NOT IN SCHOOL
96 REFUSED
99 DON'T KNOW/NOT SURE

[ASK IF AT LEAST ONE CHILD IN HOME IS UNDER 6-YEARS- OLD (FROM E8c), AND IS IN SCHOOL (FROM E8e) OR REFUSED/DON'T KNOW IF IN SCHOOL, SKIP IF E7=96/99]

F8b. Please tell us about the pre-school aged child who has missed the most school days due to illness or injury in the past 12 months. How many days of school did that child miss?

01 RESPONDENT GAVE NUMBER

ENTER NUMBER

02 NONE

03 NOT APPLICABLE

96 REFUSED

99 DON'T KNOW/NOT SURE 
[ASK IF AT LEAST ONE MEMBER OF HOUSEHOLD IS 5 TO 18-YEARS-OLD (FROM E8c), AND IS IN SCHOOL (FROM E8e) OR REFUSED/DON'T KNOW IF IN SCHOOL, SKIP IF E7=96/99]

F8c. Please tell us about the school aged child who has missed the most school days due to illness or injury in the past 12 months. How many days of school did that child miss?

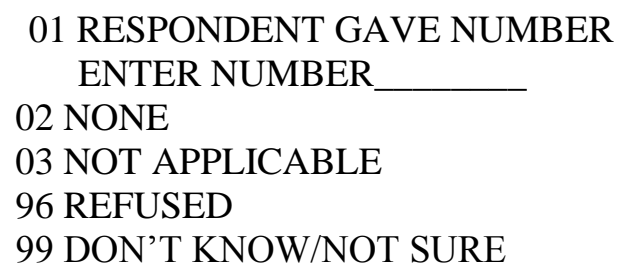

\section{SKIP IF E7=96/99}

F9. [IF E8e=01 FOR RESPONDENT, ] In the past 12 months, how frequently did you find it hard to study in your home because of excessive heat or cold? (READ)

01 Very frequently

02 Frequently

03 Not frequently or infrequently

04 Infrequently

05 Very infrequently

06 Never

07 DOES NOT STUDY AT HOME (IF VOLUNTEERED)

96 REFUSED

99 DON'T KNOW/NOT SURE

F10. \{ IF AT LEAST ONE MEMBER OF HOUSEHOLD IS 5 TO 18 OR UNDER (FROM E8c) AND IN SCHOOL (FROM E8e, SKIP IF E7=96/99) \}In the past 12 months, how frequently did any school aged child in the home find it hard to study because of excessive heat or cold? (READ)

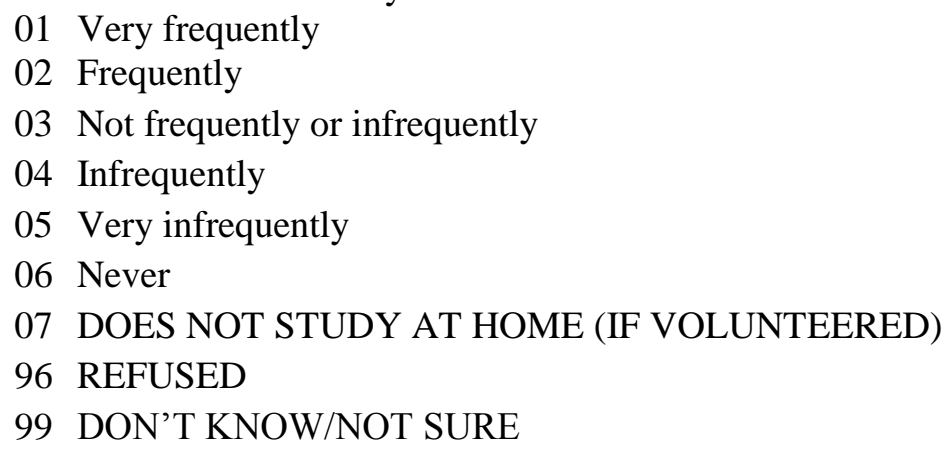

\section{G. DEMOGRAPHICS}

G1. Are you currently...? (READ)

01 Married

02 Divorced

03 Widowed

04 Separated

05 Never married

06 A member of an unmarried couple

96 REFUSED 


\section{DON'T KNOW/NOT SURE}

G2 What is the highest degree or level of school you have completed? (DO NOT READ)

01 No Schooling Completed

02 Kindergarten to grade 12 (No Diploma)

03 High school diploma or GED

04 Some college, no degree

05 Associate's degree (for example: AA, AS)

06 Bachelor's degree (for example: BA, BS)

07 Master's degree (for example: MA, MS, MBA)

08 Professional degree (for example: MD, JD)

09 Doctorate degree (for example: $\mathrm{PhD}, \mathrm{EdD}$ )

96 REFUSED

99 DON'T KNOW/NOT SURE

G3. Do you consider yourself to be of Hispanic or Latino origin, such as Mexican, Puerto Rican, Cuban, or other Spanish background?

01 Yes

02 No

96 REFUSED

99 DON'T KNOW/NOT SURE

G4. Which describes your race? You can select one or more categories. (READ)

01 White

02 Black or African-American

03 American Indian or Alaska Native

04 Asian

05 Native Hawaiian or Other Pacific Islander

97 OTHER (SPECIFY

07 HISPANIC OR LATINO (IF VOLUNTEERED)

96 REFUSED

99 DON'T KNOW/NOT SURE

G4a. \{IF MORE THAN ONE RESPONSE IN G4\} Which ONE of these groups best represents your race? (READ)

01 White

02 Black or African-American

03 American Indian or Alaska Native

04 Asian

05 Native Hawaiian or Other Pacific Islander

97 OTHER (SPECIFY )

07 HISPANIC OR LATINO (IF VOLUNTEERED)

96 REFUSED

99 DON'T KNOW/NOT SURE 
G5. Were you born a citizen of the United States or did you become a citizen of the United States through naturalization?

01 Born

02 Naturalized

03 NEITHER (IF VOLUNTEERED)

96 REFUSED

99 DON'T KNOW/NOT SURE

In this next section, I will be asking you about your home and the area where you live.

G6. Which of the following best describes the location of your home? Do you live in a city, a town, the suburbs, or in a rural area?
01 City
02 Town
03 Suburbs
04 Rural
96 REFUSED
99 DON'T KNOW/NOT SURE

G8. In the past 12 months has anyone in your household owned or had the regular use of any cars, trucks, vans, sports-utility-vehicles or similar vehicles? Do not include motorcycles or mopeds. [IF NECESSARY: "Regular use" means the vehicle is kept at home and is available for some personal use.]
01 Yes
02 No
96 REFUSED
99 DON'T KNOW/NOT SURE

G9. Thinking of the area where you live, in the past 12 months, have members of your household had regular access to public transportation? Remember to include buses, trolley buses, trains, trams, rapid transit such as the metro, subway, or underground, water taxi or ferries, free transportation offered by community services agencies, Medicaid covered transportation.
01 Yes
02 No
96 REFUSED
99 DON'T KNOW/NOT SURE

That is the end of the survey. Thank you for your participation! In appreciation of your time, we will be sending you a $\$ 20$ check in the mail.

M1. Is your mailing address [INSERT CLIENT ADDRESS FROM SAMPLE]?

01 Yes

02 No

96 REFUSED

99 DON'T KNOW/NOT SURE

IF M1=02, 96, 99:

M1a. Can you please tell me your mailing address?

RECORD:

Thank you, and have a nice day. 